This manuscript has been accepted for publication in Precambrian Research.

This is a post-print version, prior to proofing, and has not been altered or enhanced in any way for readability, error correction, or to appear similar to the published version.

This version differs slightly to the final published version which is available via the 'Peer-reviewed Publication DOI'

https://doi.org/10.1016/i.precamres.2020.105849

Corresponding author email: jarred.lloyd@adelaide.edu.au

This accepted manuscript is made available as per Elsevier's sharing policy https://www.elsevier.com/about/policies/sharing.

(c) 2020. This manuscript version is made available under the CC-BY-NC-ND 4.0 license http://creativecommons.org/licenses/by-nc-nd/4.0/ 
This accepted manuscript is a post-print version made available as per Elsevier's sharing policy under a CC-BY-NC-ND license. The final peer reviewed publication in Precambrian Research can be found at https://doi.org/10.1016/i.precamres.2020.105849

\section{Neoproterozoic Geochronology and Provenance of the}

\section{Adelaide Superbasin}

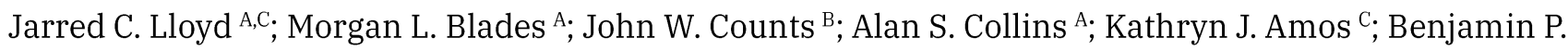

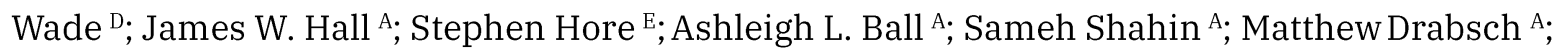
A. Tectonics and Earth Systems Group, Mawson Centre for Geoscience, and MinEx CRC, Department of Earth Sciences, The University of Adelaide, Adelaide, SA 5005, Australia
B. Irish Centre for Research in Applied Geosciences (iCRAG), O’Brien Centre for Science, University College Dublin, Belfield, Dublin 4, Ireland
C. Australian School of Petroleum and Energy Resources, The University of Adelaide, Adelaide, SA 5005, Australia
D. Adelaide Microscopy, The University of Adelaide, Adelaide, SA 5005, Australia
E. Geological Survey of South Australia, 101 Grenfell St, Adelaide, SA 5000, Australia

\section{Short Title}

Adelaide Superbasin geochronology and provenance

\section{Abstract}

The Adelaide Superbasin (Adelaide Rift Complex, Stuart Shelf, Torrens Hinge Zone, Coombalarnie Platform, and Cambrian Stansbury and Arrowie Basins) is a vast sedimentary basin in southern Australia that initiated due to the break-up of central Rodinia and, evolved into the Australian passive margin on edge of the Pacific Basin. Rocks within it contain evidence for the evolving earth system through the Neoproterozoic, including type sections of the Ediacaran fauna, Sturtian and Marinoan glaciations, and the GSSP for the base of the Ediacaran period. Much research over the last century has unravelled the lithostratigraphy and sedimentology of the basin. Despite this, the rocks are poorly dated, and their sedimentary provenance and link with tectonic geography is poorly known. This poor chronology hampers global and local efforts to gain a detailed understanding and chronological framework of the interplay between tectonics and momentous changes to the earth system during this time. This paper presents a comprehensive database of detrital zircon geochronology and review of 
This accepted manuscript is a post-print version made available as per Elsevier's sharing policy under a CC-BY-NC-ND license. The final peer reviewed publication in Precambrian Research can be found at https://doi.org/10.1016/j.precamres.2020.105849

geochronology for the Neoproterozoic of the Adelaide Superbasin, highlighting the stratigraphic, and spatial locations of available data.

In the north of the basin, zircons were sourced locally in the initial stages of rifting, ca. 830

Ma-from the adjacent Gawler Craton and Curnamona Province. During the late Tonian, detritus was transported along graben from the north-west, from the Musgrave Orogen, as the rift basin developed during the opening of the nascent Pacific Ocean. Cryogenian icesheets punctuate the detrital record with an ephemeral return to more localised rift shoulder sources. In the Ediacaran, there is an increasing influence of younger $(<740 \mathrm{Ma})$ detrital zircon from an enigmatic source that we interpret to be from southern (i.e. Antarctic) sources, with a corresponding shift in the late Mesoproterozoic age peaks, from ca. 1180 Ma to ca. 1090 Ma, and corresponding decrease in older, ca. $1600 \mathrm{Ma}$, detritus. These changes in sediment source reflect the changing tectonic geography and large-scale environmental influence of the Cryogenian glaciations as the basin evolved from a local rift, to a larger rift basin and finally to a continental margin, with sedimentary input becoming increasingly restricted over time.

\section{Keywords:}

Adelaide Superbasin; Adelaide Geosyncline; Adelaide Fold Belt; detrital zircon; Adelaide Rift Complex; Neoproterozoic

\section{Introduction}

The Neoproterozoic, particularly during the transition from Rodinia to Gondwana, is a pivotal time in Earth's history. The reconfiguration of the continental plates coincided with climatic extremes; near-global glaciations, a significant and stable rise in atmospheric oxygen levels, and the proliferation of eukaryotic and metazoan life (Bao et al. 2008; Brasier \& Lindsay 2001; Brocks 2018; Brocks et al. 2017; Campbell \& Squire 2010; Cox et al. 2016; Gernon et al. 2016; Halverson et al. 2009; Hoffman et al. 2017; Hoffman \& Li 2009; Kasemann et al. 2005; Knoll \& Carroll 1999; Knoll \& Walter 1992; Maruyama \& Santosh 2008; Meert \& Lieberman 2008; Santosh 2010; Schmidt \& Williams 1995; Squire et al. 2006; Ward et al. 2019). Much of the evidence for these events has been reported from rocks within the Adelaide Superbasin, such as key 
This accepted manuscript is a post-print version made available as per Elsevier's sharing policy under a CC-BY-NC-ND license. The final peer reviewed publication in Precambrian Research can be found at https://doi.org/10.1016/i.precamres.2020.105849

54 sequences of the Cryogenian global glaciations (Le Heron et al. 2011; Rose et al. 2013), Ediacaran Acraman

55 bolide ejecta layer (Williams 1986; Williams \& Gostin 2005), the eponymous Ediacaran fauna (Gehling \&

56 Droser 2012; Sprigg 1948) and the global boundary stratotype section and point (GSSP) for the base of the

57 Ediacaran (Knoll et al. 2006). Yet, our knowledge of the chronology and tectonic evolution of the region is

58 presently a hindrance to the calibration of other investigative techniques like chemostratigraphy, and the

59 development of time and global correlation frameworks for all of these earth system events and stratigraphic

60 sequences. While much work has been done to this end around the globe, particularly in Canada (Leslie

61 2009; Milton et al. 2017), China (Condon et al. 2005; Rooney et al. 2020), Svalbard (Halverson et al. 2018),

62 Namibia (Lamothe et al. 2019; Miller 2013; Nascimento et al. 2017), and Scotland (Dempster et al. 2002;

63 MacLennan et al. 2018; Noble et al. 1996), geochronology of the Neoproterozoic sequences remains a

64 significant challenge due to the fragmented, eroded, and commonly deformed stratigraphic record for the

65 Neoproterozoic (Halverson et al. 2018; MacLennan et al. 2018). Here we review and present new data for the

66 geochronology of arguably the most complete Neoproterozoic basin in the world, the Adelaide Superbasin

67 [Figure 1, Figure 3]. 
This accepted manuscript is a post-print version made available as per Elsevier's sharing policy under a CC-BY-NC-ND license. The final peer reviewed publication in Precambrian Research can be found at https://doi.org/10.1016/j.precamres.2020.105849

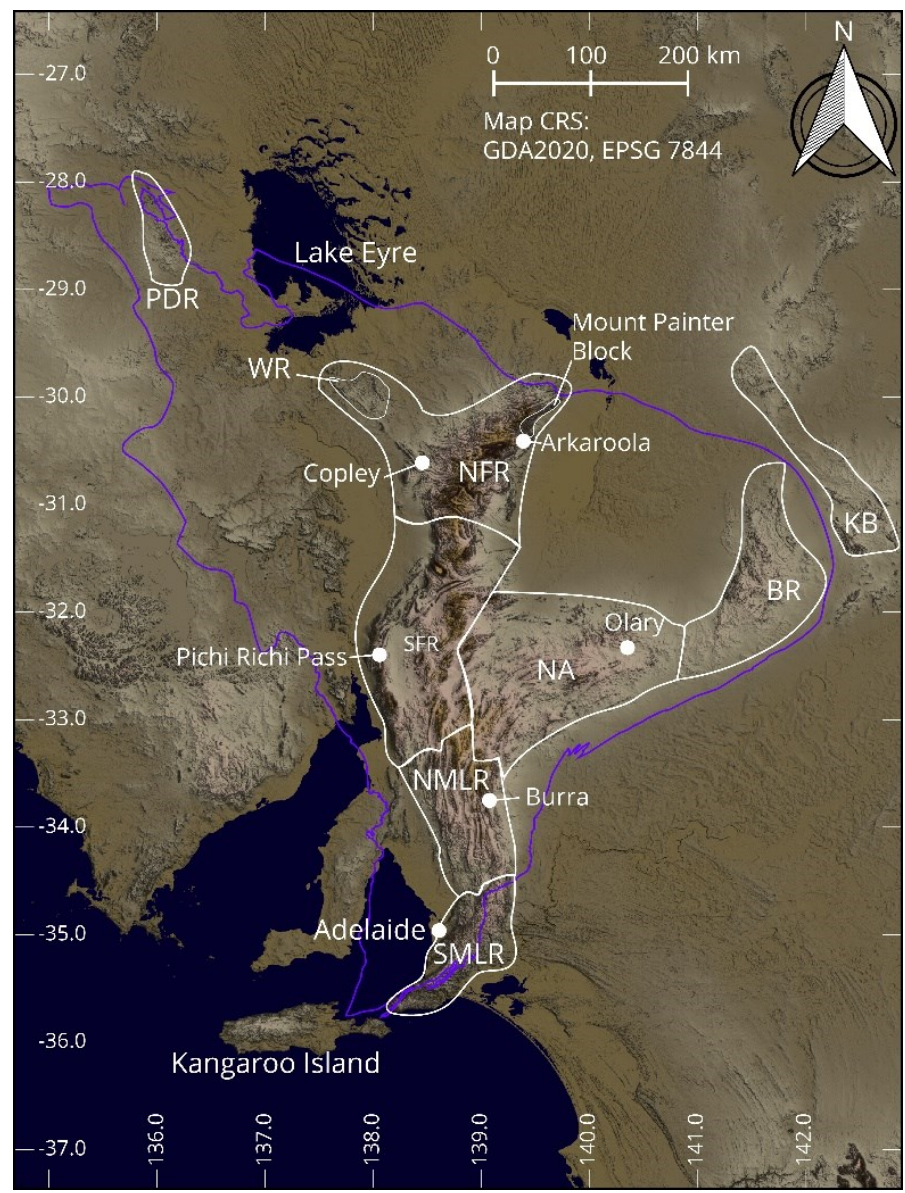

Figure 1 - General location map of the Neoproterozoic component of the Adelaide Superbasin (purple solid outline), with geographic regions (white outlines) and names used in this publication. PDR: Peake and Denison Ranges; WR: Willouran Ranges; NFR: North Flinders Ranges; SFR: South Flinders Ranges; NMLR: North Mount Lofty Ranges; SMLR: South Mount Lofty Ranges; NA: Nackara Arc; BR: Barrier Ranges; KB: Koonenberry Belt. Base map is a (false) colour shade overlain by a hill shade DEM image generated from publicly available shuttle radar topography mission (SRTM) data from NASA. For geological subdivisions of the Adelaide Superbasin the reader is referred to Figure 3.

75 This paper presents new detrital zircon U-Pb data and summarises previously published detrital zircon 76 geochronological data from the Neoproterozoic of the Adelaide Superbasin. The intention is to highlight 77 current data, present new data, and identify gaps in the geochronology of the Neoproterozoic of the Adelaide

78 Superbasin. This work will form the basis of ongoing research to develop a detailed chronostratigraphic and 79 sedimentary provenance framework of the Neoproterozoic portion of the Adelaide Superbasin, with aims to 80 explore the evolving tectonic geography of the Adelaide Superbasin and the nascent Pacific Basin.

\section{2. Background}

\subsection{Australia and Laurentia in Rodinia}

83 Though much contention still exists about the configuration of Rodinia, it is widely accepted that Australia- 
This accepted manuscript is a post-print version made available as per Elsevier's sharing policy under a CC-BY-NC-ND license. The final peer reviewed publication in Precambrian Research can be found at https://doi.org/10.1016/i.precamres.2020.105849

84 East Antarctica were attached to the western margin of Laurentia in Rodinia (Merdith et al. (2017a) and

references therein). There are currently five proposed models [Figure 2]: South-West United States - East

Antarctica (SWEAT-Dalziel 1991; Hoffman 1991; Moores 1991), Australia-Western United States

(AUSWUS-Brookfield 1993; Karlstrom et al. 1999), Australia-Mexico (AUSMEX-Wingate et al. 2002), and

however, they differ in the position of Australia-East Antarctica relative to Laurentia.

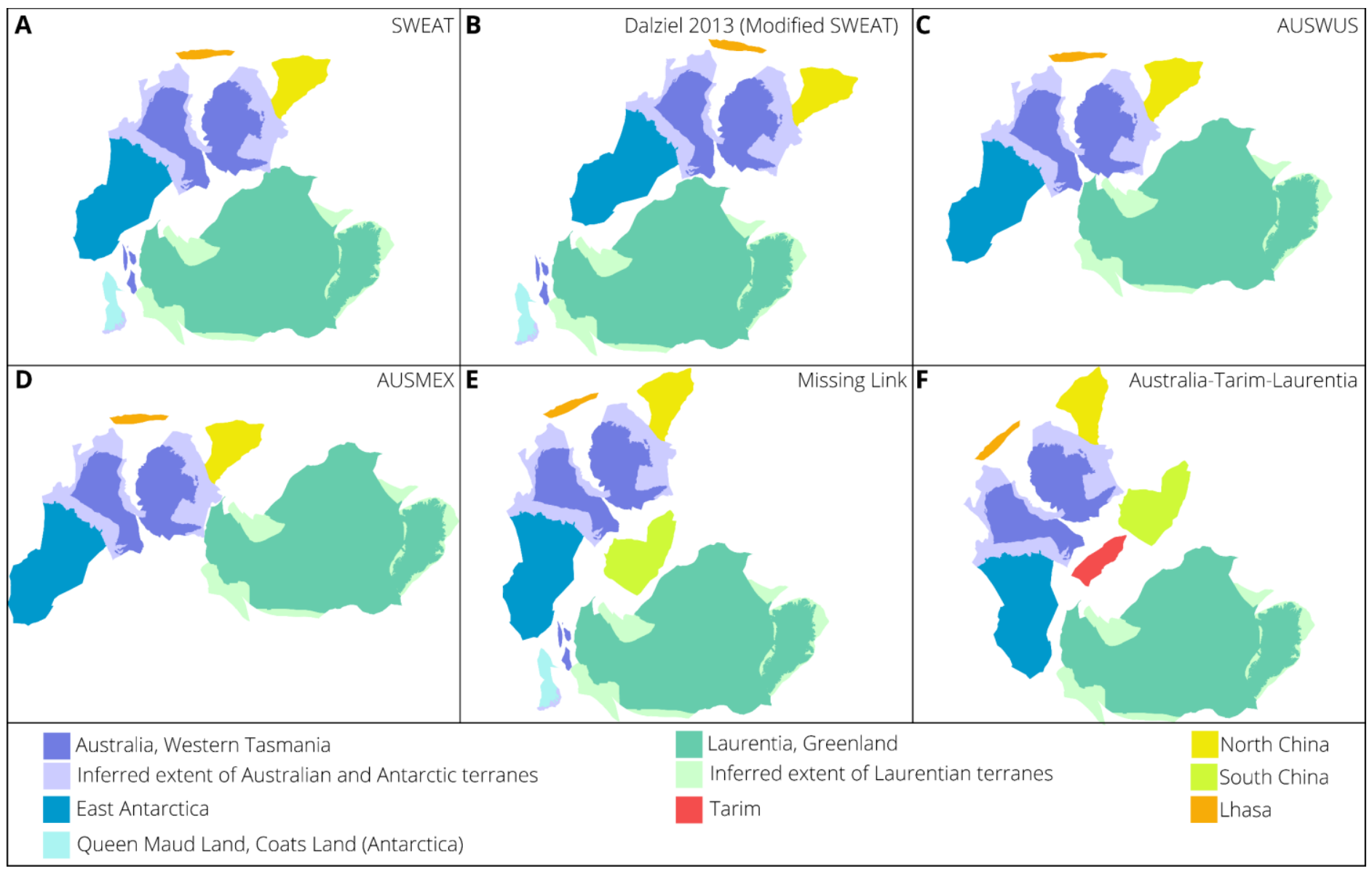

Figure 2 - Reconstructions of Rodinia (A) South-West United States-East Antarctica (SWEAT) (Dalziel 1991; Hoffman 1991; Moores 1991); (B) Modified SWEAT (Dalziel 2013) ; (C) Australia-Western United States (AUSWUS) (Brookfield 1993; Karlstrom et al. 1999); (D) Australia-Mexico (AUSMEX) (Wingate et al. 2002); (E) Australia-South China-Laurentia (Missing Link) (Li et al. 2008; Li et al. 1995); (F) Australia-Tarim-Laurentia (Wen et al. 2017; Wen et al. 2018). Original SWEAT configuration based on the GPlates model of Mulder et al. (2020). Positions and rotations of continental blocks are relative to a fixed Laurentia.

97 The timing of the Rodinia continental breakup has also been contentious, with suggestions ranging from

98 before ca. $750 \mathrm{Ma}$ (Li \& Powell 2001; Mulder et al. 2020; Wingate \& Giddings 2000), ca. $700 \mathrm{Ma}$ (Powell et al.

99 1994; Preiss 2000); ca. 600 Ma (Direen \& Crawford 2003) through to ca. 540 Ma (Veevers et al. 1997).

100 Merdith et al. (2017b), recently investigated the kinematic implications of these configurations and timings 
This accepted manuscript is a post-print version made available as per Elsevier's sharing policy under a CC-BY-NC-ND license. The final peer reviewed publication in Precambrian Research can be found at https://doi.org/10.1016/j.precamres.2020.105849

101 and concluded that breakup must have occurred before ca. 725 Ma to develop the geography of Palaeozoic

102 Gondwana. Merdith et al. (2017b) also concluded that a missing-link configuration was unlikely based on the 103 plate kinematic considerations (see also Cawood et al. 2020).

104 2.2. The Adelaide Superbasin and the Adelaide Rift Complex

105 2.2.1. Basin Hierarchy and Historical Chronostratigraphy

106 Previously termed the Adelaide Geosyncline (Mawson \& Sprigg 1950), the Adelaide Superbasin(Preiss 2000;

107 Preiss et al. 2002) is a large Neoproterozoic to middle Cambrian sedimentary system at the south-eastern

108 margin of Proterozoic Australia (Boger 2011; Cawood 2005; Cawood \& Korsch 2008; Direen \& Crawford

109 2003; Li \& Powell 2001; Myers et al. 1996; Preiss 2000; Walter \& Veevers 1997). It is akin to the Centralian

110 Superbasin (Munson et al. 2013; Walter \& Veevers 1997) regarding age and hierarchy, i.e. containing large

111 scale (up to $\sim 1000 \mathrm{~km}$ length) named basins and sub-basins. The central Adelaide Superbasin is here named

112 to include the rocks of the Adelaide Rift Complex (ARC), the contiguous undeformed rocks of the Torrens

113 Hinge Zone, the Stuart Shelf (Sprigg 1952), and Coombalarnie Platform (Callen 1990). It also includes the

114 Cambrian Arrowie and Stansbury Basins (Dalgarno 1964; Wopfner 1972). The Arrowie Basin includes

115 Yalkalpo Sub-basin (Callen 1990), and the Stansbury Basin includes the Kanmantoo Trough/Province [Figure

116 3]. Pending formal redefinition, we suggest that the Adelaide Superbasin is an appropriate name for the

117 whole sequence of Neoproterozoic to middle Cambrian rocks of south-east Proterozoic/Palaeozoic Australia

118 with the name "Adelaide Rift Complex" restricted for the series of Neoproterozoic rift-passive margin basins,

119 with which this paper is concerned. This change alleviates confusion and pays respect to the historical

120 naming (Preiss 2000; Sprigg 1952), whilst updating it to suit modern tectonic theory. As such, further

121 reference to the Adelaide Rift Complex (ARC) specifically refers to the Neoproterozoic basin and not the

122 entire Adelaide Superbasin. 
This accepted manuscript is a post-print version made available as per Elsevier's sharing policy under a CC-BY-NC-ND license. The final peer reviewed publication in Precambrian Research can be found at https://doi.org/10.1016/i.precamres.2020.105849

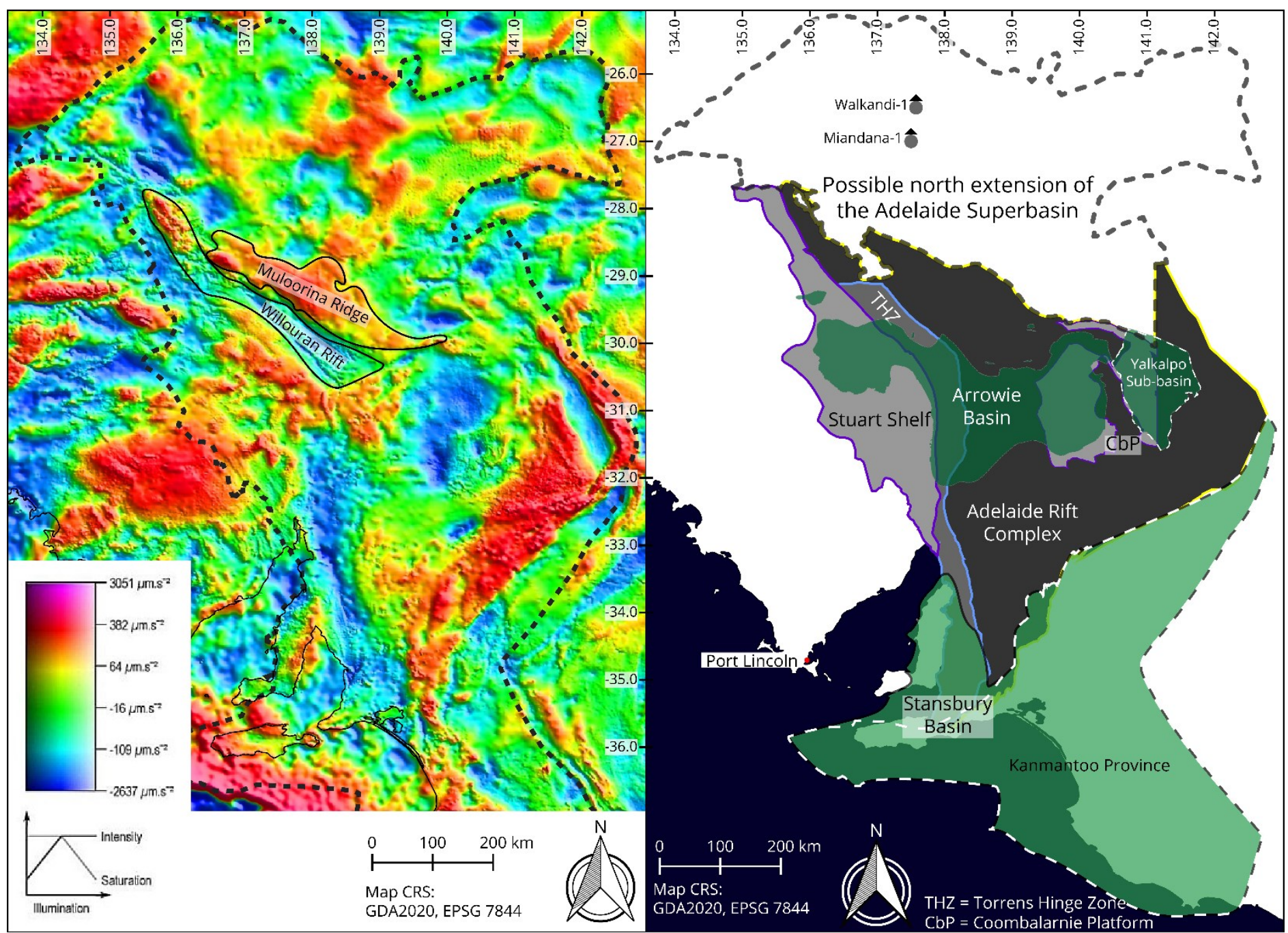

Figure 3 - [Left] Gravity anomaly hue-saturation-intensity (HSI) image showing the Muloorina Ridge, Willouran Rift and outline of the Adelaide Superbasin. (Gravity data from Geoscience Australia WMS server). [Right] The Adelaide Superbasin and its constituent components. Grey shades represent the Neoproterozoic components and green shades represent the Cambrian components. The Kanmantoo Province is a subdivision of the Stansbury Basin, and the Yalkalpo Sub-basin is a subdivision of the Arrowie Basin, both are outlined by a white dash line. The northern extension is based on limited data from drill holes (grey circle with triangle) and structures within the gravity anomaly and total magnetic intensity images (data from Geoscience Australia) and thus remains speculative. Province data acquired from the South Australian Resources Information Gateway (SARIG) and Geoscience Australia (Raymond 2018).

131 Historically, "Adelaidean" was used as a chronostratigraphic term of the era rank that was divided into the

Willouran, Torrensian, Sturtian and Marinoan periods (Drexel et al. 1993; Mawson \& Sprigg 1950; Preiss

1987). This was prior to consensus definition of the Neoproterozoic era with Tonian, Cryogenian and

Ediacaran periods (Gradstein et al. 2005). Prior to 1995, much of the literature on the Adelaide Superbasin

uses these terms, which are not are not well defined with respect to time and had boundaries defined by

lithostratigraphic groups, some of which are now superseded, conflating chronostratigraphy and 
This accepted manuscript is a post-print version made available as per Elsevier's sharing policy under a CC-BY-NC-ND license. The final peer reviewed publication in Precambrian Research can be found at https://doi.org/10.1016/i.precamres.2020.105849

- The Willouran period was defined as being represented by the Callanna Group; ca. 850-790 Ma.

- The Torrensian period began at the base of the Burra Group and continued through to the top of the Bungarider Subgroup of the Burra Group; ca. 790-730 Ma.

- The Sturtian period stretched from the base of the Belair Subgroup of the Burra Group to the top of Nepouie Subgroup of the Umberatana Group; ca. 730-640 Ma.

- The Marinoan period started at the base of the Upalinna Subgroup of the Umberatana Group, continued through the remainder of the Umberatana Group to the top of the Wilpena Group; ca. 640-541 Ma. glaciation events (Hoffman et al. 2017) and Adelaidean refers to the stratigraphy of the Adelaide Superbasin.

\subsubsection{Geology and Significance}

152 The development of the Adelaide Superbasin occurred as Laurentia (and possibly an intervening continent) began to rift from Australia-East Antarctica within Rodinia. Sedimentation is suggested to have begun just prior to ca. 830 Ma from gradual subsidence of a peneplained stable craton that developed into a rift basin

155 (Counts 2017; Powell 1998; Powell et al. 1994; Preiss 1987; 1988; 2000). After ca. 725 Ma-the latest time

156 for the break-up of Australia-East Antarctica and Laurentia, assuming Neoproterozoic plate velocities similar 157 to the Phanerozoic (Merdith et al. 2017b)-deposition within the Adelaide Superbasin continued in a mainly 158 passive margin setting along the western margin of the Palaeo-Pacific (Cawood 2005; Powell et al. 1994), 159 with renewed Ediacaran rifting and magmatism outboard of the major outcrop belts of the presently exposed 160 basin (Meffre et al. 2004). Deposition in the Adelaide Superbasin continued through to the middle Cambrian 161 (Powell 1998; Powell et al. 1994; Preiss 1987; 1988; 2000) and was terminated by the onset of the 162 Delamerian Orogeny (Foden et al. 2006; Foden et al. 2020 ; Preiss 2000). 
This accepted manuscript is a post-print version made available as per Elsevier's sharing policy under a CC-BY-NC-ND license. The final peer reviewed publication in Precambrian Research can be found at https://doi.org/10.1016/i.precamres.2020.105849

164 the northernmost regions of South Australia, narrowing in the South Mount Lofty Ranges at the Fleurieu

165 Peninsula and extending into Kangaroo Island [Figure 1]. Although the original basin spans over 1,100

166 kilometres in length from central Australia to the eastern tip of Kangaroo Island [Figure 1, Figure 1], the

167 majority of the basin is buried beneath younger sedimentary basins; with approximately $600 \mathrm{~km}$ north-south

168 cropping out day [Figure 4]. The northernmost extension of the Adelaide Superbasin is not well understood,

169 but it has been suggested that the Muloorina Ridge [Figure 3]-a poorly understood gravity high previously

170 interpreted as an ancient triple junction (von der Borch 1980)-may have been the northern limit of the basin

171 until the late Ediacaran (Preiss 1987; 1990; Thomson 1970), although this remains speculative (Counts \&

172 Amos 2016). Walkandi-1 (Richards 1982) and Miandana-1(Martin 1986) are two drill holes north of the

173 Muloorina Ridge that have intersected stratigraphy described as Adelaidean, yet further correlation is

174 speculative. 
This accepted manuscript is a post-print version made available as per Elsevier's sharing policy under a CC-BY-NC-ND license. The final peer reviewed publication in Precambrian Research can be found at https://doi.org/10.1016/i.precamres.2020.105849

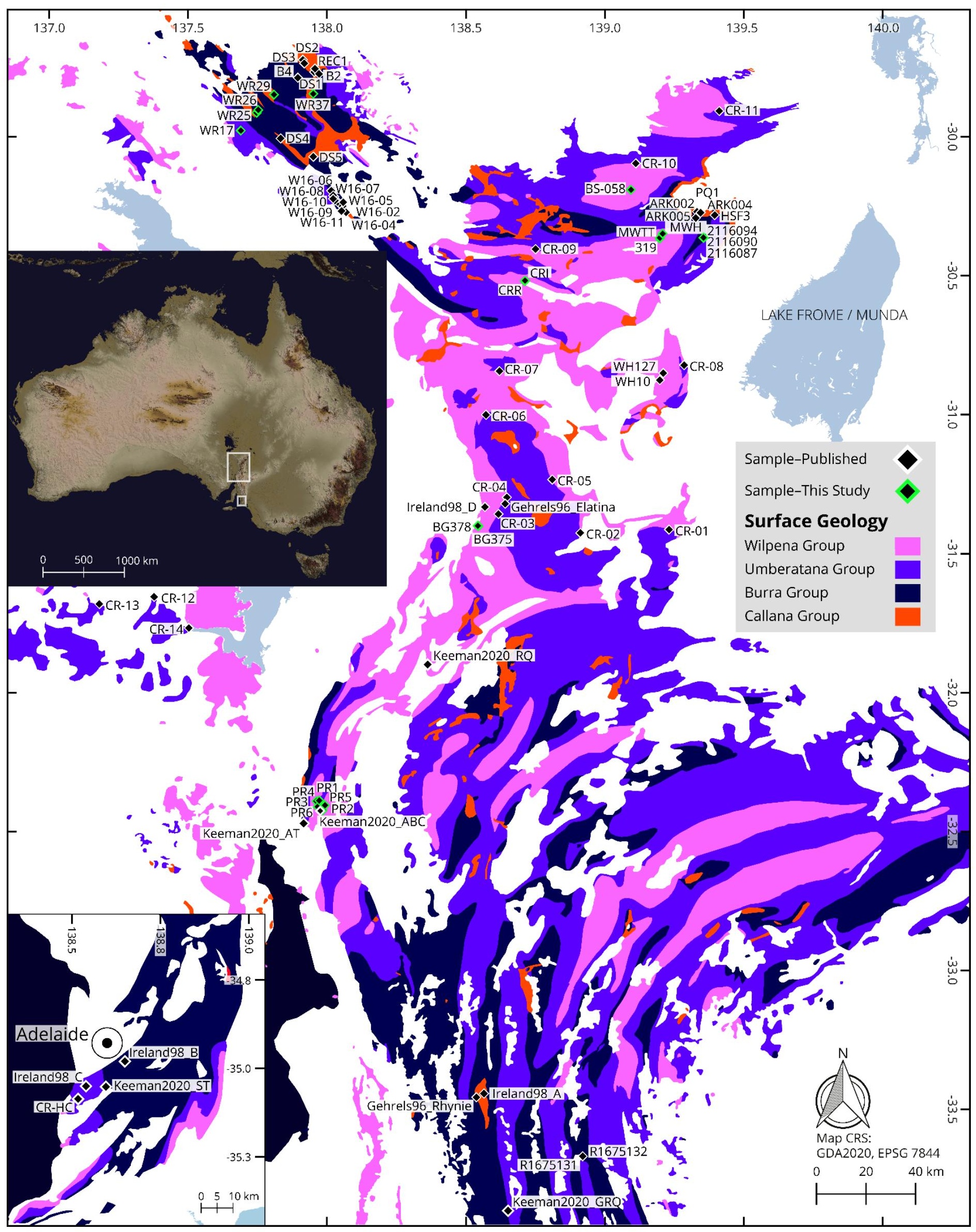

(C) 2020. This manuscript version is made available under the CC-BY-NC-ND 4.0 license http://creativecommons.org/licenses/by-nc-nd/4.0/ 
This accepted manuscript is a post-print version made available as per Elsevier's sharing policy under a CC-BY-NC-ND license. The final peer reviewed publication in Precambrian Research can be found at https://doi.org/10.1016/i.precamres.2020.105849

Figure 4 - Sample locations and surface geology map of the Neoproterozoic Adelaide Rift Complex. Surface geology is shown by group. Top inset shows location relative to Australia (a false colour hill shade based on publicly available 7.5s SRTM DEM data from NASA). Bottom inset shows samples near Adelaide. A full list of sample locations can be found in the supplementary dataset (Lloyd et al. 2020) (link is provided in Data Availability). Surface geology data from SARIG.

To the west of the Adelaide Superbasin, the Gawler Craton [Figure 5] is comprised of Archaean and predominately Palaeoproterozoic to earliest Mesoproterozoic age rocks (Daly et al. 1998; Hand et al. 2007). Within the Gawler Craton, the major tectonic and magmatic events are: the Sleafordian Orogeny (2600-2400 Ma), emplacement of the Donnington Granitoid Suite (1850-1840 Ma), the Lincoln Complex (Kimban Orogeny; 1790-1710 Ma), the Gawler Range Volcanics and associated intrusive Hiltaba suite at ca. $1590 \mathrm{Ma}$ and a final emplacement event ca. $1450 \mathrm{Ma}$ (Morrissey et al. 2019). It has been interpreted that the intrusion of the basaltic Gairdner Dyke Swarm at ca. $827 \mathrm{Ma}$ (Wingate et al. 1998), was the result of a mantle plume associated with the initiation of rifting and formation of the Adelaide Superbasin. The Curnamona Province [Figure 5] lies to the east of the central Adelaide Superbasin and is late Palaeoproterozoic to early Mesoproterozoic in age, generally correlating with the younger components of the Gawler Craton (Coats \& Blissett 1971; Compston et al. 1966; Elburg et al. 2001; Preiss 2000; Teale 1993; Willis et al. 1983). Preiss (2000) interpreted the existence of a late Palaeoproterozoic precursor basin occupying a similar extent to that of the Neoproterozoic Adelaide Rift Complex, with sedimentation and volcanism between ca. 1750$1650 \mathrm{Ma}$, and deformation at ca. $1600 \mathrm{Ma}$. 
This accepted manuscript is a post-print version made available as per Elsevier's sharing policy under a CC-BY-NC-ND license. The final peer reviewed publication in Precambrian Research can be found at https://doi.org/10.1016/j.precamres.2020.105849

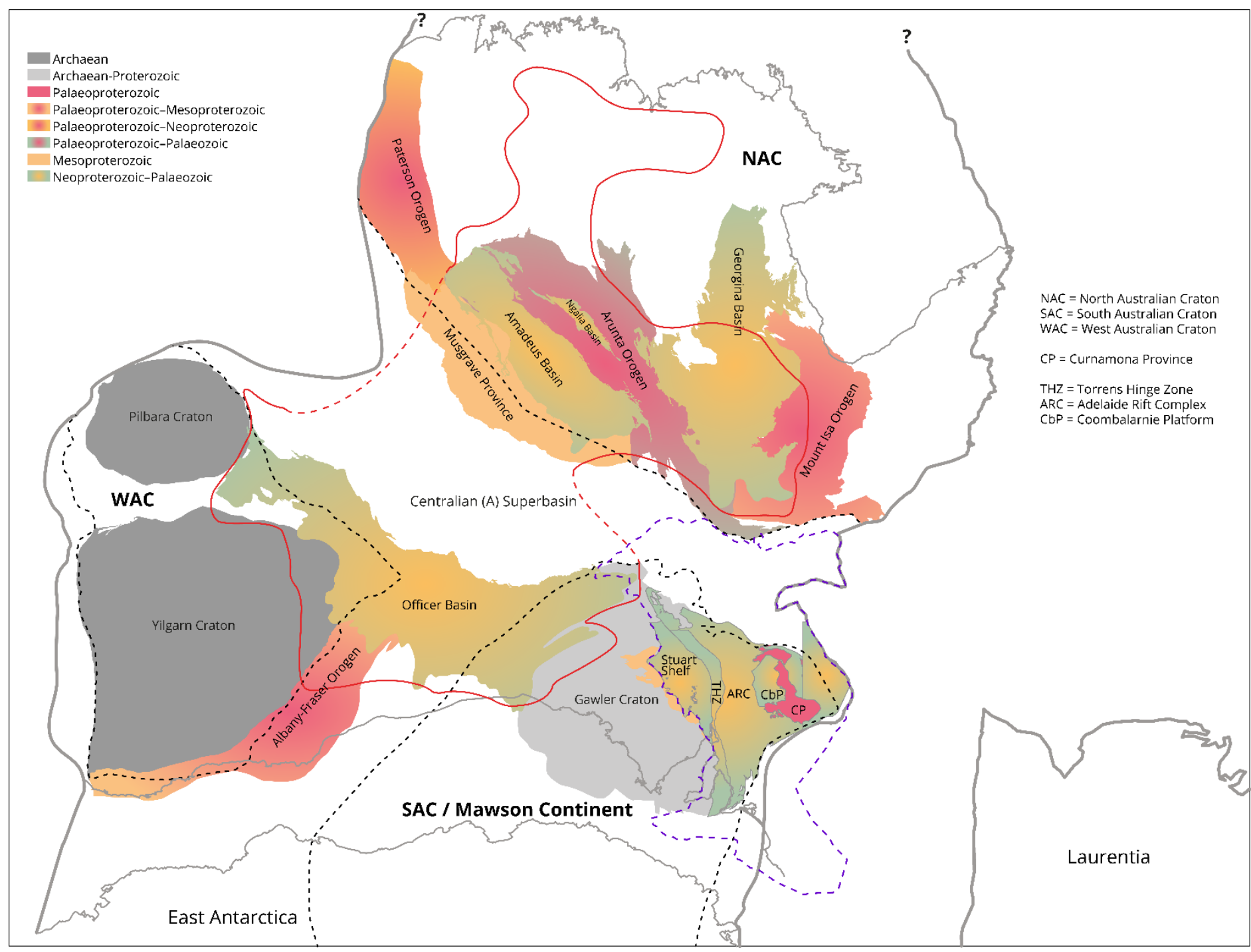


This accepted manuscript is a post-print version made available as per Elsevier's sharing policy under a CC-BY-NC-ND license. The final peer reviewed publication in Precambrian Research can be found at https://doi.org/10.1016/j.precamres.2020.105849

Figure 5 - Reconstruction of Neoproterozoic Australia, ca. 700 Ma, showing known extent of the Neoproterozoic component of the Adelaide Superbasin (Stuart Shelf, Adelaide Rift Complex, Coombalarnie Platform, Torrens Hinge Zone), the proposed extent of the entire Adelaide Superbasin (purple dashed line, present day position), select Australian potential source terranes and coeval sedimentary basins. Black dashed lines represent boundaries of the North Australian Craton, South Australian Craton and West Australian Creation. The Centralian A Superbasin (Munson et al. 2013) is represented by a solid red line for modern day known extent and a dashed red line for inferred boundaries during the Neoproterozoic. Thick grey lines represent inferred

Neoproterozoic continental outline and thinner grey lines represent modern day coastlines. Rotation of the NAC based on the model of Li and Evans (2010). Province data from Geoscience Australia (Raymond 2018) and SARIG. Original outline of Australia and Antarctica is from www.naturalearthdata.com 
This accepted manuscript is a post-print version made available as per Elsevier's sharing policy under a CC-BY-NC-ND license. The final peer reviewed publication in Precambrian Research can be found at https://doi.org/10.1016/i.precamres.2020.105849

201

202

203

204

205

206

207

208

209

210

211

212

213

214

215

216

217

218

219

220

221

222

223

224

225

226

Within the Adelaide Superbasin there are at least five major rift cycles, each marked by associated faulting, minor volcanism, and distinct depositional sequences (Preiss 2000; Walter et al. 2000). It has been suggested that rifting within the Adelaide Superbasin initiated at ca. 827-802 Ma (Fanning et al. 1986; Jenkins et al. 2002; Wingate et al. 1998). The sedimentary sequences of the Adelaide Superbasin have been separated into three supergroups (Preiss 1982). The Warrina Supergroup that encompasses the Tonian early rift sequences, the Heysen Supergroup comprising the Cryogenian and Ediacaran glacial, interglacial and post-glacial sedimentary rocks, and the Moralana Supergroup that encompasses all the Cambrian sedimentary rocks (Preiss 1982; 2000). It is not well established when rifting terminated; however, evidence of large-scale normal faulting is not seen after the early Cryogenian (Preiss 2000). Deposition ceased and the sedimentary rocks were deformed and folded during the Cambro-Ordovician Delamerian Orogeny ca. 514-490 Ma (Drexel \& Preiss 1995; Foden et al. 2006; Foden et al. 2020; Preiss 2000).

The Warrina Supergroup includes the Callanna and Burra Groups and is largely restricted to depositional fault-bound troughs (Powell et al. 1994). These groups are dominated by clastic and carbonate rocks, with evaporitic rocks and mafic volcanic rocks forming important constituents of the Callanna Group (Powell et al. 1994). The Heysen Supergroup, comprised of the Umberatana and Wilpena Groups, is considered to represent a period of thermal sag following deposition of the Warrina Supergroup that was largely controlled by tectonic subsidence (Preiss 1987). The Umberatana Group is made up of a thick interglacial succession (up to $\sim 4.5 \mathrm{~km}$ thick) in the centre of the basin marked by the Sturtian glacial deposits (e.g. the Appila Tillite) defining the base, and the Marinoan glacial sequences (e.g., the Elatina Formation) characterising the top (Powell et al. 1994; Preiss 2000). The Wilpena Group records the Ediacaran post-glacial sequence, which shoals upwards into predominately sandstones (Powell et al. 1994; Preiss 2000). The two Neoproterozoic supergroups are followed by transgressive early Cambrian shallow-marine sandstones and deeper water carbonates and shales of the Moralana Supergroup, which includes all the Cambrian sedimentary rocks of the Adelaide Superbasin (Powell et al. 1994; Preiss 2000). Though not the 
This accepted manuscript is a post-print version made available as per Elsevier's sharing policy under a CC-BY-NC-ND license. The final peer reviewed publication in Precambrian Research can be found at https://doi.org/10.1016/i.precamres.2020.105849

focus of this study, the Moralana Supergroup includes, the Normanville Group made of limestone; sandstone; shale and volcanics, the Kanmantoo Group including marine metasandstone, phyllite, schist, gneiss, minor calcsilicate and marble, and the Lake Frome Group, composed of sandstone, siltstone, shale, limestone and conglomerate (Zang et al. 2004). A tuff within the Normanville Group dates its deposition to $514.98 \pm 0.63 \mathrm{Ma}$ (U-Pb TIMS; Betts et al. 2018), very close to the $514 \pm 5$ Ma crystallisation age of the Rathjen Gneiss (Foden et al. 1999), which is the oldest intrusion so-far dated into the overlying Kanmantoo Group (Foden et al. 2006).

The lack of reliable age constraints within the Adelaide Superbasin is in part due to the scarcity of syn-depositional (felsic) magmatism throughout the rock sequences. In addition, few detrital zircon studies have been undertaken. As a result, the depositional history, evolution of the basin sedimentary pathways and the wider tectonic geography of the area remain enigmatic. Preiss (2000) and Mahan et al. (2010) have previously summarised the available geochronology of the Adelaidean sedimentary rocks that were available at the time. Succeeding this, several studies have analysed detrital zircon from various formations from throughout the Neoproterozoic of the Adelaide Superbasin. Rose et al. (2013), published an extensive dataset of detrital zircon U-Pb ages from the Elatina Formation and equivalents. Cox et al. (2018), published a new U-Pb tuff age of $663.03 \pm$ $0.11 \mathrm{Ma}$ from the Wilyerpa Formation (in the Umberatana Group), as well as providing detrital zircon $\mathrm{U}-\mathrm{Pb}$ age data from one sample of the Bolla Bollana Formation and one sample of the Tapley Hill Formation (mistakenly published as Bolla Bollana Formation) Most recently Keeman et al. (2020) published new data detrital zircon U-Pb geochronology and other isotopic data from a number of both Neoproterozoic and Cambrian formations of the Adelaide Superbasin. There have also been several research degree studies that have generated, but not formally published, detrital zircon U-Pb geochronology data (Drabsch 2016; Job 2011; Mackay 2011; Shahin 2016). All chronological ages from the Neoproterozoic of the Adelaide Superbasin discussed in this paper are summarised in Figure 6. 
This accepted manuscript is a post-print version made available as per Elsevier's sharing policy under a CC-BY-NC-ND license. The final peer reviewed publication in Precambrian Research can be found at https://doi.org/10.1016/i.precamres.2020.105849

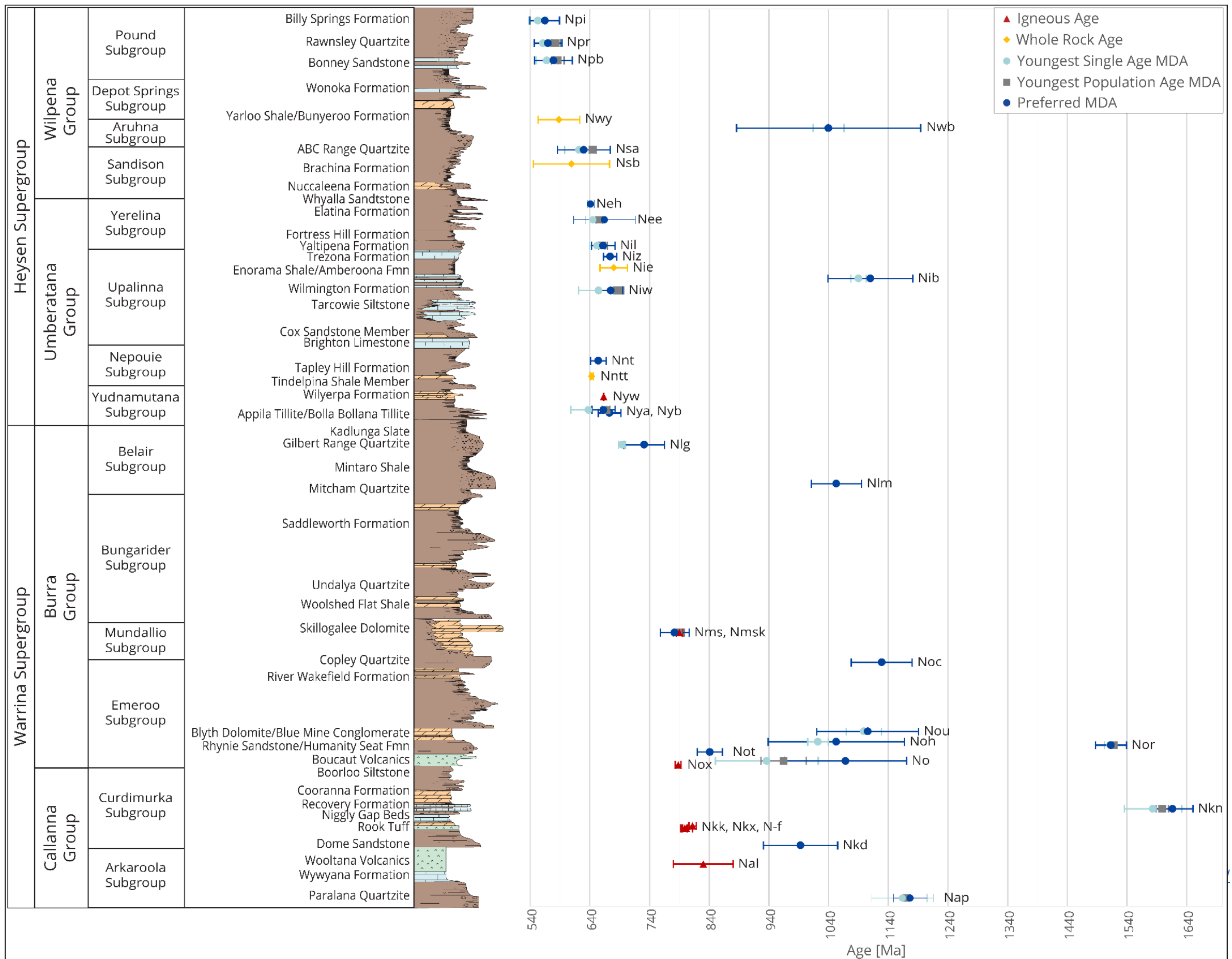


This accepted manuscript is a post-print version made available as per Elsevier's sharing policy under a CC-BY-NC-ND license. The final peer reviewed publication in Precambrian Research can be found at https://doi.org/10.1016/j.precamres.2020.105849

253 Figure 6 - [Right] Composite, generalised and representative lithological log of the Neoproterozoic of the Adelaide Superbasin (adapted from Preiss (2000)). [Left] Within-basin chronological constraints relative to stratigraphic position. This lithological log does not represent the true thickness of lithologies, spatial variation of formations across the basin nor the detail of each

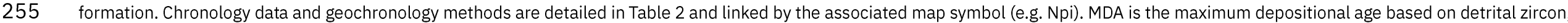
details of the method for choosing MDAs are detailed in 3.3. The spatial relationships of these data are shown in Figure 7. 
This accepted manuscript is a post-print version made available as per Elsevier's sharing policy under a CC-BY-NC-ND license. The final peer reviewed publication in Precambrian Research can be found at https://doi.org/10.1016/i.precamres.2020.105849

Using detrital muscovite ${ }^{40} \mathrm{Ar}-{ }^{39} \mathrm{Ar}$ data on formations with previously published detrital zircon $\mathrm{U}-\mathrm{Pb}$

geochronology (Ireland et al. 1998), Haines et al. (2004) suggested that at the initiation of the infill of the

basin, sediments were supplied from the younger parts of the Gawler Craton and Curnamona Province. The

whole-rock Sm-Nd isotope data from the Neoproterozoic sedimentary rocks of the Adelaide Superbasin are

also more radiogenic than most Gawler Craton basement, with the erosion of the Gairdner Dykes (and

possible volcanic equivalents) being a possible explanation for this (Barovich \& Foden 2000; Haines et al.

Ma aged input, suggesting inundation from the Musgrave Orogen, to the north and west of the Gawler Craton

[Figure 5] (Haines et al. 2004). Previous research has suggested that an abrupt change in detrital zircon ages

occurs at the base of the Cambrian Kanmantoo Group, where Ediacaran/Cambrian (600-500 Ma) and

Stenian 1200-1000 Ma dominate (Ireland et al. 1998). This may reflect a late influx of southerly-derived

detritus as subduction of the Pacific Ocean began forming topography as the Ross Orogen developed (Foden

et al. 2006).

\section{Methods}

271 Data were obtained from publications, theses, and analyses of new samples from relatively understudied

272 formations within the Neoproterozoic of the Adelaide Superbasin-Figure 4 shows the locations of samples

273 in used this study. All data was subject to the same statistical analysis as outlined in section 3.3. The link to

274 the U-Pb detrital zircon dataset for the Adelaide Rift Complex is found in Data Availability.

\section{3.1. Prior Data}

276 Detrital zircon data was collated from prior peer-reviewed publications and theses, constituting a total of 55 277 samples from 23 formations, and two samples from an undifferentiated Emeroo subgroup lithology [Figure

278 4]. The formations these data are from are-in reverse stratigraphic order (oldest first)-the Paralana

279 Quartzite, the Dome Sandstone, the Recovery Formation, the Niggly Gap Beds, the Humanity Seat Formation, 280 the Emeroo Subgroup (undifferentiated), the Rhynie Sandstone, the Blue Mine Conglomerate, the Copley 281 Quartzite, the Skillogalee Dolomite, the Mitcham Quartzite, the Gilbert Range Quartzite, the Bolla Bollana 
This accepted manuscript is a post-print version made available as per Elsevier's sharing policy under a CC-BY-NC-ND license. The final peer reviewed publication in Precambrian Research can be found at https://doi.org/10.1016/i.precamres.2020.105849

282 Tillite, the Appila Tillite, the Tapley Hill Formation, the Wilmington Formation (Marino Arkose Member), the

283 Yaltipena Formation, the Trezona Formation, the Elatina Formation, the Whyalla Sandstone, the ABC Range

284 Quartzite, the Bunyeroo Formation, the Bonney Sandstone, and the Rawnsley Quartzite.

285 Of these, 34 samples from 15 formations are published in peer reviewed journals (Compston et al. 1987; Cox

286 et al. 2018; Gehrels et al. 1996; Ireland et al. 1998; Keeman et al. 2020; Preiss et al. 2009; Rose et al.

287 2013). The remainder of these data are from research theses (Drabsch 2016; Job 2011; Shahin 2016;

288 Mackay 2011). Figure 7 shows the spatial, stratigraphic and time relationships of the formations these data

289 are from, highlighting the saturations and gaps in our current knowledge base, the importance of formally

290 publishing the theses data, and directing the ongoing and future research to fill the gaps in our current

291 knowledge base. 
This accepted manuscript is a post-print version made available as per Elsevier's sharing policy under a CC-BY-NC-ND license. The final peer reviewed publication in Precambrian Research can be found at https://doi.org/10.1016/i.precamres.2020.105849

\begin{tabular}{|c|c|c|c|c|c|c|c|c|}
\hline$\underline{y}$ & Subgroup & Stuart Shelf & $\begin{array}{l}\text { South Mount Lofty } \\
\text { Ranges }\end{array}$ & $\begin{array}{l}\text { North Mount Lofty } \\
\text { Ranges }\end{array}$ & Nackara Arc & South Flinders Ranges & North Flinders Ranges & $\begin{array}{l}\text { North Flinders Ranges } \\
\text { (Willouran Ranges) }\end{array}$ \\
\hline \multirow{7}{*}{$\begin{array}{ll}\frac{1}{\pi} \\
\frac{\pi}{0} \\
\frac{\pi}{0} \\
\frac{\pi}{0} \\
\end{array}$} & \multirow{3}{*}{ Pound } & & & & & & \multirow{2}{*}{$\begin{array}{c}\text { Billy Springs Formation } \\
(564 \pm 25 \mathrm{Ma}) \\
\text { Billy Springs Formation/ } \\
\text { Rawnsely Quarzite }\end{array}$} & \\
\hline & & & & & & $\begin{array}{c}\text { Rawnsley Quartzite } \\
(570 \pm 23 \mathrm{Ma})\end{array}$ & & \\
\hline & & & & & & $\begin{array}{c}\text { Bonney Sandstone } \\
(579 \pm 32 \mathrm{Ma}) \\
\end{array}$ & $\begin{array}{c}\text { Bonney Sandstone } \\
(579 \pm 32 \mathrm{Ma}) \\
\end{array}$ & \\
\hline & \begin{tabular}{|l} 
Depot Springs \\
\end{tabular} & & & & & & & \\
\hline & Aruhna & $\mid \begin{array}{c}\text { Yarloo Shale } \\
(588 \pm 35 \mathrm{Ma} \text { Rb-Sr) }\end{array}$ & & & & & & \\
\hline & \multirow[b]{2}{*}{ Sandision } & & & & & $\begin{array}{c}\text { ABC Range Quartzite } \\
(630 \pm 16 \mathrm{Ma})\end{array}$ & & \\
\hline & & \begin{tabular}{|c|}
$\begin{array}{c}\text { Tregolana Shale } \\
\text { Member } \\
(676 \pm 200 \mathrm{Ma} \mathrm{Rb}-\mathrm{Sr})\end{array}$ \\
\end{tabular} & & & & $\begin{array}{l}\text { Brachina Formation } \\
(609 \pm 64 \mathrm{Ma} \text { Rb-Sr) }\end{array}$ & & \\
\hline \multirow{9}{*}{ 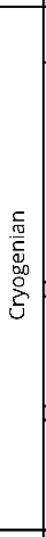 } & Yerelina & \begin{tabular}{|c|}
$\begin{array}{c}\text { Whyalla Sandstone } \\
(641 \pm 5 \mathrm{Ma})\end{array}$ \\
\end{tabular} & $\begin{array}{c}\text { Elatina Formation } \\
(671 \pm 52 \mathrm{Ma})\end{array}$ & & & \multicolumn{2}{|c|}{$\begin{array}{c}\text { Elatina Formation } \\
(671 \pm 52 \mathrm{Ma})\end{array}$} & \\
\hline & \multirow{4}{*}{ Upalinna } & & & & & $\begin{array}{c}\text { Yaltipena Formation } \\
(662 \pm 20 \mathrm{Ma})\end{array}$ & & \\
\hline & & & & & & & $\begin{array}{c}\text { Trezona Formation } \\
(674 \pm 11 \mathrm{Ma})\end{array}$ & \\
\hline & & & \begin{tabular}{|c|}
$\begin{array}{c}\text { Wilmington Formation } \\
(688 \pm 8 \mathrm{Ma})\end{array}$ \\
\end{tabular} & & & & $\begin{array}{c}\text { Enorama Shale } \\
(680 \pm 23 \mathrm{Ma})\end{array}$ & \\
\hline & & & Marino Arkose member & & & & & $\begin{array}{c}\text { Amberoona Formation } \\
(1110 \pm 71 \mathrm{Ma})\end{array}$ \\
\hline & \multirow{2}{*}{ Nepouie } & & & & & & $\begin{array}{c}\text { Tapley Hill Formation } \\
(654 \pm 13 \mathrm{Ma})\end{array}$ & \\
\hline & & & & & & & \begin{tabular}{|c|} 
Tindelpina Shale Member \\
$(643 \pm 2.4 \mathrm{Ma}$ Re-Os) \\
\end{tabular} & \\
\hline & \multirow{2}{*}{ Yudnamutana } & & & & & & $\begin{array}{l}\text { Tuff in Wilyerpa } \\
(663 \pm 0.11 \mathrm{Ma}) \\
\end{array}$ & \\
\hline & & & & & & & & $\begin{array}{c}\text { Bolla Bollana Tillite } \\
(673 \pm 19 \mathrm{Ma}) \\
\end{array}$ \\
\hline \multirow{16}{*}{$\stackrel{\frac{1}{0}}{\frac{.0}{0}}$} & \multirow[t]{2}{*}{ Belair } & & & \begin{tabular}{|c|} 
Glibert Range Quartzite \\
$(731 \pm 34 \mathrm{Ma})$
\end{tabular} & & & & \\
\hline & & & $\begin{array}{c}\text { Mitcham Quartzite } \\
(1053 \pm 53 \mathrm{Ma})\end{array}$ & & & & & \\
\hline & \begin{tabular}{|l} 
Bungarider \\
\end{tabular} & & & & & & & \\
\hline & \multirow[b]{2}{*}{ Mundallio } & & & \multicolumn{5}{|c|}{$\begin{array}{l}\text { Skillogalee Dolomite } \\
\text { (789 } 9 \mathrm{Ma})\end{array}$} \\
\hline & & & & \multicolumn{5}{|c|}{ Kooringa Member (ca. $790 \mathrm{Ma}$ ) } \\
\hline & \multirow{5}{*}{ Emeroo } & & & & & & & $\begin{array}{r}\text { Copley Quartzite } \\
(1129 \pm 51 \mathrm{Ma}) \\
\end{array}$ \\
\hline & & & & & & & \begin{tabular}{|c|}
$\begin{array}{c}\text { Blue Mine Conglomerate } \\
(1106 \pm 85 \mathrm{Ma})\end{array}$ \\
\end{tabular} & \\
\hline & & & $\begin{array}{c}\text { Rhynie Sandstone } \\
(1513 \pm 26 \mathrm{Ma})\end{array}$ & & & & & \\
\hline & & & & & & & \begin{tabular}{|c|}
$\begin{array}{c}\text { Humanity Seat Formation } \\
(1053 \pm 114 \mathrm{Ma})\end{array}$ \\
\end{tabular} & \begin{tabular}{|c}
$\begin{array}{c}\text { Top Mount Sandstone } \\
(841 \pm 21 \mathrm{Ma})\end{array}$ \\
\end{tabular} \\
\hline & & & & & $\begin{array}{l}\text { Boucaut Volcanics } \\
\text { (ca. } 788 \mathrm{Ma} \text { ) }\end{array}$ & & & \\
\hline & & & \begin{tabular}{|c|} 
Mount Crawford Granite \\
Gneiss \\
$(812 \pm 6 \mathrm{Ma})$ \\
\end{tabular} & & & & & \\
\hline & \multirow[t]{3}{*}{ Curdimurka } & & & $\begin{array}{c}\text { Niggly Gap } \\
(1571 \pm 12 \mathrm{Ma})\end{array}$ & & & & \\
\hline & & & & & \begin{tabular}{|c|} 
Oodla Wirra Volcanics \\
$(798 \pm 5 \mathrm{Ma}, 799 \pm 4 \mathrm{Ma})$
\end{tabular} & & & $\begin{array}{c}\text { Rook Tuff } \\
(802 \pm 10 \mathrm{Ma})\end{array}$ \\
\hline & & & & & & & & $\begin{array}{c}\text { Dome Sandstone } \\
(993 \pm 62 \mathrm{Ma})\end{array}$ \\
\hline & \multirow{2}{*}{ Arkaroola } & $\begin{array}{c}\text { Gairdner Dolerite } \\
(826 \pm 7 \mathrm{Ma})\end{array}$ & & & & & $\begin{array}{c}\text { Wooltana Volcanics } \\
(830 \pm 50 \mathrm{Ma})\end{array}$ & \\
\hline & & & & & & & $\begin{array}{c}\text { Paralana Quartzite } \\
(1177 \pm 28 \mathrm{Ma})\end{array}$ & \\
\hline
\end{tabular}


This accepted manuscript is a post-print version made available as per Elsevier's sharing policy under a CC-BY-NC-ND license. The final peer reviewed publication in Precambrian Research can be found at https://doi.org/10.1016/i.precamres.2020.105849

Figure 7 - Current chronological constraints within the Neoproterozoic of the Adelaide Superbasin with relation to spatial and stratigraphic position. Purple shading indicates non-detrital constraints (Compston et al. 1987; Cox et al. 2018; Fabris et al. 2005; Fanning et al. 1986; Kendall et al. 2006; Mahan et al. 2010; Preiss et al. 2009; Preiss et al. 2008; Webb 1980; Wingate et al. 1998), yellow shading represents new and theses data, and grey shaded areas represent unconformities as per previous literature. White bounded boxes are prior peer-reviewed detrital zircon data (Gehrels et al. 1996; Gostin et al. 1986; Ireland et al. 1998; Keeman et al. 2020; Rose et al. 2013). This is not a complete stratigraphic correlation of the Adelaide Superbasin, and gaps in chronological data are represented by the white shaded, non-bordered areas. Geographic regions are defined in Figure 1

\subsection{New Data}

Twenty-two new samples from nine formations were analysed for $\mathrm{U}-\mathrm{Pb}$ detrital zircon data. The formations these data are from are-in reverse stratigraphic order-the Top Mount Sandstone, the Skillogalee Dolomite, the Amberoona Formation, the Elatina Formation, the Wilmington Formation, the ABC Range Quartzite, the Bonney Sandstone, the Rawnsley Quartzite, and the Billy Springs Formation.

\subsection{1. $\quad U-P b$ Geochronology}

All new zircon samples were imaged via cathodoluminescence on an XL40 scanning electron microscope and analysed using Laser Ablation Inductively Coupled Plasma Mass Spectrometry (LA-ICP-MS). Two different instruments were used to obtain data from these new samples. Analysis was either conducted on a Resonetics M50-193 laser ablation system coupled with an Agilent 7700s ICP-MS or a New Wave UP-213 laser ablation system coupled with an Agilent 7500 cs ICP-MS, both instruments are housed at Adelaide Microscopy, University of Adelaide, Australia. Analytical methodology followed standard methods of Payne et al. (2006). A variety of primary and secondary standards were analysed every 10-20 unknowns. These were GEMOC GJ-1 (TIMS normalising ages ${ }^{207} \mathrm{~Pb} /{ }^{235} \mathrm{U} 602.0 \pm 1.0 \mathrm{Ma} ;{ }^{206} \mathrm{~Pb} /{ }^{238} \mathrm{U} 600.7 \pm 1.1 \mathrm{Ma} ;{ }^{207} \mathrm{~Pb} /{ }^{206} \mathrm{~Pb} 607.7$ \pm 4.3 Ma; Jackson et al. 2004), Plešovice (ID-TIMS ${ }^{206} \mathrm{~Pb} /{ }^{238} \mathrm{U}$ Age, $337.13 \pm 0.37 \mathrm{Ma}$; Sláma et al. 2008), $91500\left(\right.$ TIMS ${ }^{207} \mathrm{~Pb} /{ }^{206} \mathrm{~Pb} 1065.4 \pm 0.3 \mathrm{Ma}$; Wiedenbeck et al. 1995) and an in-house Sri Lankan zircon standard (BJWP-1; ca. 727 Ma). Data were processed either using GLITTER (Jackson et al. 2004) or Iolite (Paton et al. 2011) depending on the year collected. Standards data are presented in Table 1. 
This accepted manuscript is a post-print version made available as per Elsevier's sharing policy under a CC-BY-NC-ND license. The final peer reviewed publication in Precambrian Research can be found at https://doi.org/10.1016/i.precamres.2020.105849

Table 1 - Standards Data

\begin{tabular}{|c|c|c|c|c|c|c|c|}
\hline Samples & Equipment & $\begin{array}{l}\text { Processing } \\
\text { Software }\end{array}$ & Standard & & ${ }^{207} \mathrm{~Pb} /{ }^{235} \mathrm{U}$ & ${ }^{206} \mathrm{~Pb} /{ }^{238} \mathrm{U}$ & ${ }^{207} \mathrm{~Pb} /{ }^{206} \mathrm{~Pb}$ \\
\hline \multirow[t]{2}{*}{$\begin{array}{l}\text { PR1, PR2, PR3, } \\
\text { PR4, PR5, PR6 }\end{array}$} & $\begin{array}{l}\text { New Wave UP- } \\
213 \text { laser with }\end{array}$ & \multirow[t]{2}{*}{ GLITTER } & GEMOC GJ-1 & Primary & $601.5 \pm 0.86 \mathrm{Ma} ; \mathrm{MSWD}=1.50$ & $600.37 \pm 0.82 \mathrm{Ma} ; \mathrm{MSWD}=0.92$ & $605.5 \pm 4 \mathrm{Ma} ; \mathrm{MSWD}=0.86$ \\
\hline & $\begin{array}{l}\text { Agilent } 7500 \mathrm{cs} \\
\text { ICP-MS }\end{array}$ & & Plešovice & Secondary & $329.88 \pm 0.84 \mathrm{Ma} ; \mathrm{MSWD}=2.60$ & $331.62 \pm 0.76 \mathrm{Ma} ; \mathrm{MSWD}=2.80$ & $317.40 \pm 6.10 \mathrm{Ma} ; \mathrm{MSWD}=0.98$ \\
\hline \multirow{2}{*}{$\begin{array}{l}2116087 \\
2116090 \\
2116094\end{array}$} & $\begin{array}{l}\text { New Wave UP- } \\
213 \text { laser with }\end{array}$ & \multirow[t]{2}{*}{ GLITTER } & GEMOC GJ-1 & Primary & $600.24 \pm 0.77 \mathrm{Ma} ; \mathrm{MSWD}=0.96$ & $600 \pm 0.76 \mathrm{Ma} ; \mathrm{MSWD}=0.70$ & $602.29 \pm 3.22 \mathrm{Ma} ; \mathrm{MSWD}=0.65$ \\
\hline & $\begin{array}{l}\text { Agilent } 7500 \mathrm{cs} \\
\text { ICP-MS }\end{array}$ & & Plešovice & Secondary & $328.76 \pm 0.83 \mathrm{Ma} ; \mathrm{MSWD}=1.65$ & $332.19 \pm 0.72 \mathrm{Ma} ;$ MSWD = 3.00 & $316 \pm 5.71$ Ma; MSWD 0.96 \\
\hline \multirow[t]{2}{*}{$\begin{array}{l}058 \\
(03 / 07 / 2014)\end{array}$} & $\begin{array}{l}\text { New Wave UP- } \\
213 \text { laser with }\end{array}$ & \multirow[t]{2}{*}{ GLITTER } & GEMOC GJ-1 & Primary & $602.27 \pm 1.06 \mathrm{Ma} ; \mathrm{MSWD}=1.31$ & $600.89 \pm 0.91 \mathrm{Ma} ; \mathrm{MSWD}=0.96$ & $608.79 \pm 5.08 \mathrm{Ma} ; \mathrm{MSWD}=0.82$ \\
\hline & $\begin{array}{l}\text { Agilent } 7500 \mathrm{cs} \\
\text { ICP-MS }\end{array}$ & & Plešovice & Secondary & $340.32 \pm 1.23 \mathrm{Ma} ; \mathrm{MSWD}=28.8$ & $336.88 \pm 0.83 \mathrm{Ma} ; \mathrm{MSWD}=112$ & $334.62 \pm 9.86 \mathrm{Ma} ; \mathrm{MSWD}=0.54$ \\
\hline \multirow[t]{2}{*}{$\begin{array}{l}058 \\
(15 / 09 / 2014)\end{array}$} & $\begin{array}{l}\text { New Wave UP- } \\
213 \text { laser with }\end{array}$ & \multirow[t]{2}{*}{ GLITTER } & GEMOC GJ-1 & Primary & $602.34 \pm 1.84 \mathrm{Ma} ; \mathrm{MSWD}=0.61$ & $600.53 \pm 1 \mathrm{Ma} ; \mathrm{MSWD}=0.82$ & $611.50 \pm 9 \mathrm{Ma} ; \mathrm{MSWD}=0.64$ \\
\hline & $\begin{array}{l}\text { Agilent } 7500 \mathrm{cs} \\
\text { ICP-MS }\end{array}$ & & BJWP-1 & Secondary & $657.54 \pm 3.41$ Ma; MSWD = 7.51 & $646.42 \pm 1.68 \mathrm{Ma} ;$ MSWD = 19.3 & $723 \pm 15.4$ Ma; MSWD = 1.76 \\
\hline \multirow[t]{2}{*}{$\begin{array}{l}058 \\
(16 / 09 / 2014)\end{array}$} & $\begin{array}{l}\text { New Wave UP- } \\
213 \text { laser with }\end{array}$ & \multirow[t]{2}{*}{ GLITTER } & GEMOC GJ-1 & Primary & $602.45 \pm 1.90 \mathrm{Ma} ; \mathrm{MSWD}=0.26$ & $599.87 \pm 1.05 \mathrm{Ma} ; \mathrm{MSWD}=0.66$ & $612.65 \pm 9.39 \mathrm{Ma} ; \mathrm{MSWD}=0.33$ \\
\hline & $\begin{array}{l}\text { Agilent } 7500 \mathrm{cs} \\
\text { ICP-MS }\end{array}$ & & BJWP-1 & Secondary & $726.88 \pm 5.40 \mathrm{Ma} ; \mathrm{MSWD}=0.34$ & $702.79 \pm 2.68 \mathrm{Ma} ; \mathrm{MSWD}=0.97$ & $811.4 \pm 22.7 \mathrm{Ma} ; \mathrm{MSWD}=0.49$ \\
\hline \multirow[t]{2}{*}{319} & $\begin{array}{l}\text { New Wave UP- } \\
213 \text { laser with }\end{array}$ & \multirow[t]{2}{*}{ GLITTER } & GEMOC GJ-1 & Primary & $602.12 \pm 1.09 \mathrm{Ma} ; \mathrm{MSWD}=0.36$ & $600.37 \pm 0.64 \mathrm{Ma} ; \mathrm{MSWD}=0.60$ & $608.90 \pm 5.39 \mathrm{Ma} ; \mathrm{MSWD}=0.29$ \\
\hline & $\begin{array}{l}\text { Agilent } 7500 \mathrm{cs} \\
\text { ICP-MS }\end{array}$ & & BJWP-1 & Secondary & $707.58 \pm 2.96$ Ma; MSWD = 0.89 & $688.89 \pm 1.57 \mathrm{Ma} ;$ MSWD = 0.70 & 771.8 × 12.8 Ma; MSWD = 0.84 \\
\hline \multirow[t]{2}{*}{ BG375 } & $\begin{array}{l}\text { New Wave UP- } \\
213 \text { laser with }\end{array}$ & \multirow[t]{2}{*}{ GLITTER } & GEMOC GJ-1 & Primary & $602.26 \pm 1.77 \mathrm{Ma} ; \mathrm{MSWD}=0.51$ & $600.16 \pm 0.97 \mathrm{Ma} ; \mathrm{MSWD}=0.48$ & $608.17 \pm 8.69 \mathrm{Ma} ; \mathrm{MSWD}=0.44$ \\
\hline & $\begin{array}{l}\text { Agilent } 7500 \mathrm{cs} \\
\text { ICP-MS }\end{array}$ & & BJWP-1 & Secondary & $719.16 \pm 5.08 \mathrm{Ma} ; \mathrm{MSWD}=0.62$ & $715.60 \pm 2.56 \mathrm{Ma} ; \mathrm{MSWD}=0.45$ & $740.1 \pm 22.3 \mathrm{Ma} ; \mathrm{MSWD}=0.48$ \\
\hline \multirow[t]{2}{*}{ BG378 } & $\begin{array}{l}\text { New Wave UP- } \\
213 \text { laser with }\end{array}$ & \multirow[t]{2}{*}{ GLITTER } & GEMOC GJ-1 & Primary & $601.31 \pm 1.46 \mathrm{Ma} ; \mathrm{MSWD}=0.67$ & $599.65 \pm 0.82 \mathrm{Ma} ; \mathrm{MSWD}=1.52$ & $611.40 \pm 7.16 \mathrm{Ma} ; \mathrm{MSWD}=0.40$ \\
\hline & $\begin{array}{l}\text { Agilent } 7500 \mathrm{cs} \\
\text { ICP-MS }\end{array}$ & & BJWP-1 & Secondary & $724.23 \pm 3.51 \mathrm{Ma} ; \mathrm{MSWD}=0.75$ & $706.98 \pm 1.85 \mathrm{Ma} ;$ MSWD = 0.63 & $774.8 \pm 14.5$ Ma; MSWD = 0.57 \\
\hline
\end{tabular}


This accepted manuscript is a post-print version made available as per Elsevier's sharing policy under a CC-BY-NC-ND license. The final peer reviewed publication in Precambrian Research can be found at https://doi.org/10.1016/j.precamres.2020.105849

Table 1 - Standards Data

\begin{tabular}{|c|c|c|c|c|c|c|c|}
\hline Samples & Equipment & $\begin{array}{l}\text { Processing } \\
\text { Software }\end{array}$ & Standard & & ${ }^{207} \mathrm{~Pb} /{ }^{235} \mathrm{U}$ & ${ }^{206} \mathrm{~Pb} /{ }^{238} \mathrm{U}$ & ${ }^{207} \mathrm{~Pb} /{ }^{206} \mathrm{~Pb}$ \\
\hline CRI & $\begin{array}{l}\text { New Wave UP- } \\
213 \text { laser with } \\
\text { Agilent } 7500 \mathrm{cs} \\
\text { ICP-MS }\end{array}$ & GLITTER & $\begin{array}{l}\text { GEMOC GJ-1 } \\
\text { BJWP-1 }\end{array}$ & $\begin{array}{l}\text { Primary } \\
\text { Secondary }\end{array}$ & $\begin{array}{l}601.74 \pm 1.67 \mathrm{Ma} ; M S W D=0.56 \\
728.02 \pm 4.33 \mathrm{Ma} ; M S W D=0.56\end{array}$ & $\begin{array}{l}601.08 \pm 0.98 \mathrm{Ma} ; \mathrm{MSWD}=0.83 \\
719.27 \pm 2.33 \mathrm{Ma} ; \mathrm{MSWD}=0.64\end{array}$ & $\begin{array}{l}609.63 \pm 8.17 \mathrm{Ma} ; M S W D=0.33 \\
752.8 \pm 18.2 \mathrm{Ma} ; M S W D=0.68\end{array}$ \\
\hline CRR & $\begin{array}{l}\text { New Wave UP- } \\
213 \text { laser with } \\
\text { Agilent } 7500 \mathrm{cs} \\
\text { ICP-MS }\end{array}$ & GLITTER & $\begin{array}{l}\text { GEMOC GJ-1 } \\
\text { BJWP-1 }\end{array}$ & $\begin{array}{l}\text { Primary } \\
\text { Secondary }\end{array}$ & $\begin{array}{l}602.41 \pm 1.44 \mathrm{Ma} ; M S W D=0.66 \\
712.61 \pm 3.50 \mathrm{Ma} ; M S W D=0.86\end{array}$ & $\begin{array}{l}601.24 \pm 0.82 \mathrm{Ma} ; \mathrm{MSWD}=0.84 \\
701.11 \pm 1.75 \mathrm{Ma} ; \mathrm{MSWD}=1.13\end{array}$ & $\begin{array}{l}609.19 \pm 7.06 \mathrm{Ma} ; \mathrm{MSWD}=0.38 \\
749.2 \pm 14.9 \mathrm{Ma} ; \mathrm{MSWD}=0.64\end{array}$ \\
\hline MWH & $\begin{array}{l}\text { New Wave UP- } \\
213 \text { laser with } \\
\text { Agilent } 7500 \mathrm{cs} \\
\text { ICP-MS }\end{array}$ & GLITTER & $\begin{array}{l}\text { GEMOC GJ-1 } \\
\text { BJWP-1 }\end{array}$ & $\begin{array}{l}\text { Primary } \\
\text { Secondary }\end{array}$ & $\begin{array}{l}602.25 \pm 1.53 \mathrm{Ma} ; M S W D=0.56 \\
640.66 \pm 2.79 \mathrm{Ma} ; M S W D=7.53\end{array}$ & $\begin{array}{l}600.01 \pm 0.83 \mathrm{Ma} ; \mathrm{MSWD}=1.35 \\
640.67 \pm 1.45 \mathrm{Ma} ; \mathrm{MSWD}=22.2\end{array}$ & $\begin{array}{l}610.33 \pm 7.53 \mathrm{Ma} ; M S W D=0.41 \\
689.6 \pm 13.2 \mathrm{Ma} ; M S W D=1.39\end{array}$ \\
\hline MWTT & $\begin{array}{l}\text { New Wave UP- } \\
213 \text { laser with } \\
\text { Agilent } 7500 \text { cs } \\
\text { ICP-MS }\end{array}$ & GLITTER & $\begin{array}{l}\text { GEMOC GJ-1 } \\
\text { BJWP-1 }\end{array}$ & $\begin{array}{l}\text { Primary } \\
\text { Secondary }\end{array}$ & $\begin{array}{l}602.10 \pm 0.87 \mathrm{Ma} ; M S W D=0.42 \\
684.29 \pm 2.0 \mathrm{Ma} ; M S W D=0.64\end{array}$ & $\begin{array}{l}600.40 \pm 0.67 \mathrm{Ma} ; M S W D=0.33 \\
665.95 \pm 1.37 \mathrm{Ma} ; M S W D=0.77\end{array}$ & $\begin{array}{l}608.34 \pm 4.11 \mathrm{Ma} ; M S W D=0.39 \\
741.41 \pm 8.47 \mathrm{Ma} ; M S W D=0.49\end{array}$ \\
\hline $\begin{array}{l}\text { WR17, WR25, } \\
\text { WR26, WR29, } \\
\text { WR37 }\end{array}$ & \begin{tabular}{|l|} 
Resonetics \\
M50-193 laser \\
with Agilent \\
7700s ICP-MS \\
\end{tabular} & IOLITE & $\begin{array}{l}\text { GEMOC GJ-1 } \\
\text { Plešovice } \\
91500\end{array}$ & $\begin{array}{l}\text { Secondary } \\
\text { Primary }\end{array}$ & $\begin{array}{l}605.27 \pm 1.15 \mathrm{Ma} ; M S W D=0.30 \\
338.40 \pm 1.41 \mathrm{Ma} ; M S W D=0.51 \\
1059.38 \pm 3.1 \mathrm{Ma} ; M S W D=0.35\end{array}$ & $\begin{array}{l}601.81 \pm 0.60 \mathrm{Ma} ; \mathrm{MSWD}=0.45 \\
338.51 \pm 0.34 \mathrm{Ma} ; \mathrm{MSWD}=0.71 \\
1053.42 \pm 2.51 \mathrm{Ma} ; \mathrm{MSWD}=0.36\end{array}$ & $\begin{array}{l}618.22 \pm 5.68 \mathrm{Ma} ; M S W D=0.31 \\
343.41 \pm 5.77 \mathrm{Ma} ; M S W D=0.34 \\
1080.2 \pm 12.6 \mathrm{Ma} ; M S W D=0.28\end{array}$ \\
\hline
\end{tabular}


This accepted manuscript is a post-print version made available as per Elsevier's sharing policy under a CC-BY-NC-ND license. The final peer reviewed publication in Precambrian Research can be found at https://doi.org/10.1016/i.precamres.2020.105849

\section{3. $\quad$ Statistics}

320 The entire dataset was analysed with the following statistical methodology to ensure consistency, reproducibility, and comparability. To determine a preferred age (aka best age) for an individual analysis we utilise the precision method (model-1) of Puetz (2018), whereby the best age is the most precise of the ${ }^{206} \mathrm{~Pb} /{ }^{238} \mathrm{U},{ }^{207} \mathrm{~Pb} /{ }^{235} \mathrm{U}$ and ${ }^{206} \mathrm{~Pb} /{ }^{207} \mathrm{~Pb}$ ages. The preferred age must also pass a test for 'reasonable ages' where $0 \mathrm{Ma}<\mathrm{X} \leq 4300 \mathrm{Ma}$. Preferred ages are then subsequently filtered into filtered ages by a formula that checks if the concordance for that grain is between 90 and 110, and that the relative uncertainty of the preferred age is less than $10 \%$. Where the ${ }^{207} \mathrm{~Pb} /{ }^{235} \mathrm{U}$ age is available concordance is calculated by using $\left(\left[{ }^{206} \mathrm{~Pb} /{ }^{238} \mathrm{U}\right] /\left[{ }^{207} \mathrm{~Pb} /{ }^{235} \mathrm{U}\right]{ }^{\star} 100\right)$ for preferred ages of less than $1000 \mathrm{Ma}$ and $\left(\left[{ }^{207} \mathrm{~Pb} /{ }^{235} \mathrm{U}\right] /\left[{ }^{207} \mathrm{~Pb} /{ }^{206} \mathrm{~Pb}\right]^{\star} 100\right)$ for preferred ages of $1000 \mathrm{Ma}$ or older. If the ${ }^{207} \mathrm{~Pb} /{ }^{235} \mathrm{U}$ age is not available concordance is calculated by using $\left(\left[{ }^{206} \mathrm{~Pb} /{ }^{238} \mathrm{U}\right] /\left[{ }^{207} \mathrm{~Pb} /{ }^{206} \mathrm{~Pb}\right]^{\star} 100\right)$. Concordance values are rounded to the nearest whole integer. This method for calculating concordance is identical, with respect to the decay systems, to that of Puetz et al. (2018).

These parameters were defined in order to retain a large dataset, prevent human bias, and discard datapoints with significantly large uncertainties on near concordant data whilst also taking into account the relative changes in precision and accuracy of the decay systems through time (Puetz et al. 2018; Spencer et function to visualise the distribution of the data. No real benefit was gained using a concordance cut off between $5 \%$ and $9 \%$ and setting it at $5 \%$ would have meant discarding approximately 1000 data points, equating to approximately $19 \%$ of the filtered data set. All preferred ages, and subsequently filtered ages, used in construction of statistical plots were chosen from original data in an unbiased manner using a formula in Microsoft ${ }^{\oplus}$ Excel $^{\mathrm{TM}}$ based on the previously described parameters. Formulas and detailed explanations of their operation are found in the workbook linked in Data Availability.

341 Grouping data by formation, these data were statistically explored using kernel density estimates (KDE) and 342 multidimensional scaling (MDS). KDE and MDS plots were generated using IsoplotR (Vermeesch 2018b) with 343 KDEs using a common bandwidth to aid visual comparison. The common bandwidth is the median bandwidth 344 of the automatically generated variable bandwidths of all samples (Vermeesch 2018b). MDS plots generated 
This accepted manuscript is a post-print version made available as per Elsevier's sharing policy under a CC-BY-NC-ND license. The final peer reviewed publication in Precambrian Research can be found at https://doi.org/10.1016/i.precamres.2020.105849

using IsoplotR use the Kolmogorov-Smirnov (KS) statistic (Vermeesch 2013; 2018b). Synthetic peaks for the

MDS plots were generated using the random number generator function of Excel ${ }^{\mathrm{TM}}$ to create 1000 points with

a standard deviation based on the estimated two sigma uncertainty equation from Puetz et al. (2018). These

synthetic peaks are an estimate of most prominent peaks (local maxima) within a KDE that combines all

filtered data from the ARC and are meant to act as anchors in the MDS to help guide the viewer to visualise

the components that contribute to the similarities of points within the MDS. The MDS plot allows us to

visualise relationships more easily between the formations, although these must be used with larger

amounts of data for more robust statistics, as such any formation with less than 40 filtered ages was

omitted. Care must be taken to only use geographically probable sources for comparative data as sources

that are not geographically probable may have similar age spectra as the terrane under investigation. Whilst

Nordsvan et al. (2020) highlight limitations of this method of MDS analysis, we use it only to look at relative

differences and there is no real need to explicitly account for analytical uncertainty (Vermeesch 2012;

2018a).

The multiple sample, 'view from above' probability density plot (PDP) was generated using FitPDF (Eglington

2018). Although both KDE and PDP have advantages and disadvantages with relation to each other, the

authors of this paper prefer the use of KDE for statistical analysis for reasons highlighted by Vermeesch

the relative changes in peak density for many samples over time. With our large dataset and use of a precision method to determine preferred ages for each analysis, the PDP and KDE plots should effectively

364 look the same.

365 In this paper, we generally quote youngest single grain (YSG) ages as maximum depositional ages (MDA)

366 rather than quoting the means of age clusters. One reasoning is that there is no a priori reason that any two

367 detrital zircon grains should have the same age within any particular sample (Dickinson \& Gehrels 2009;

368 Spencer et al. 2016; Yang et al. 2018). The data for use as YSG for MDA is determined using the same 369 methodology as filtered ages, described earlier in this section, but with a much stricter concordance level of 370 within $2 \%$ of concordance (calculated as described earlier in this section). From this we generally use the 
This accepted manuscript is a post-print version made available as per Elsevier's sharing policy under a CC-BY-NC-ND license. The final peer reviewed publication in Precambrian Research can be found at https://doi.org/10.1016/j.precamres.2020.105849

371 older of the ${ }^{207} \mathrm{~Pb} /{ }^{206} \mathrm{~Pb},{ }^{207} \mathrm{~Pb} /{ }^{235} \mathrm{U}$ and ${ }^{206} \mathrm{~Pb} /{ }^{238} \mathrm{U}$ ages as a conservative estimate for the maximum

372 depositional age, this is termed the preferred MDA [Table 2]. For completeness, the weighted mean age of

373 clusters (youngest population age, YPA) and MSWD is provided and is calculated using a formula that

374 averages grains that overlap within uncertainty of the youngest grain plus its uncertainty-this only applies

when $\mathrm{n}$ grains of the youngest overlapping population is greater than two. We utilise the equations of Wendt

and Carl (1991) and Spencer et al. (2016) for the calculation of the weighted mean and reduced chi-squared

statistic (MSWD). If there is genuine concern about the reliability of the YSG we use the YPA. The Wetherill

concordia plots for our new data were generated using IsoplotR (Vermeesch 2018b) and can be found in

379 Appendix One.

\section{Results}

381 Analysis of the twenty-two new samples yielded 3,506 new U-Pb detrital zircon datum of which 2,596 are within filtering parameters. Concordia diagrams and individual kernel density estimates for these new samples can be found in Appendix One. The remainder of the data set is from the 57 samples from prior data that is outlined earlier. These remaining samples constitute 4,090 data; 3,192 of these are within filtering parameters. The original data from these sources was reanalysed with the same statistical methodology as the unpublished data set. The results in this paper may vary from the original publications due to variations in the statistical methods used by those authors compared with the methodology described in section 3.3.

The entire dataset covers the above mentioned 27 formations with a total of 7,596 data; 5,788 of these are within filtering parameters described in section 3.3. Sample locations are shown on Figure 4 and coordinates can be found in the database linked in Data Availability. Kernel density estimates, grouped by formation are shown in Figure 8. In the following subsections [4.1, 4.2, 4.3, \& 4.4] we describe the results of the entire compiled dataset, referring to filtered zircons, which simply means zircon that fit our filtering parameters for concordance, relative uncertainty and are a "reasonable age" (i.e. greater than $0 \mathrm{Ma}$ and less or equal to

395 The combined dataset is grouped by formation and plotted as kernel density estimates [Figure 8], and a 396 "view from above" probability density plot [Figure 9] used to highlight changes in population probabilities 
This accepted manuscript is a post-print version made available as per Elsevier's sharing policy under a CC-BY-NC-ND license. The final peer reviewed publication in Precambrian Research can be found at https://doi.org/10.1016/i.precamres.2020.105849

397 through time with similarities/dissimilarities visualised in multidimensional scaling plots [Figure 10]. Figure 5 398 shows potential Australian source regions, coeval sedimentary basins and reconstruction of Neoproterozoic 399 Australia ca. 700 Ma, a key time just after the start of the Sturtian Glaciation (Hoffman et al. 2017) and 400 inferred separation of Laurentia and Australia-East Antarctica (Merdith et al. 2017a). 
This accepted manuscript is a post-print version made available as per Elsevier's sharing policy under a CC-BY-NC-ND license. The final peer reviewed publication in Precambrian Research can be found at https://doi.org/10.1016/i.precamres.2020.105849

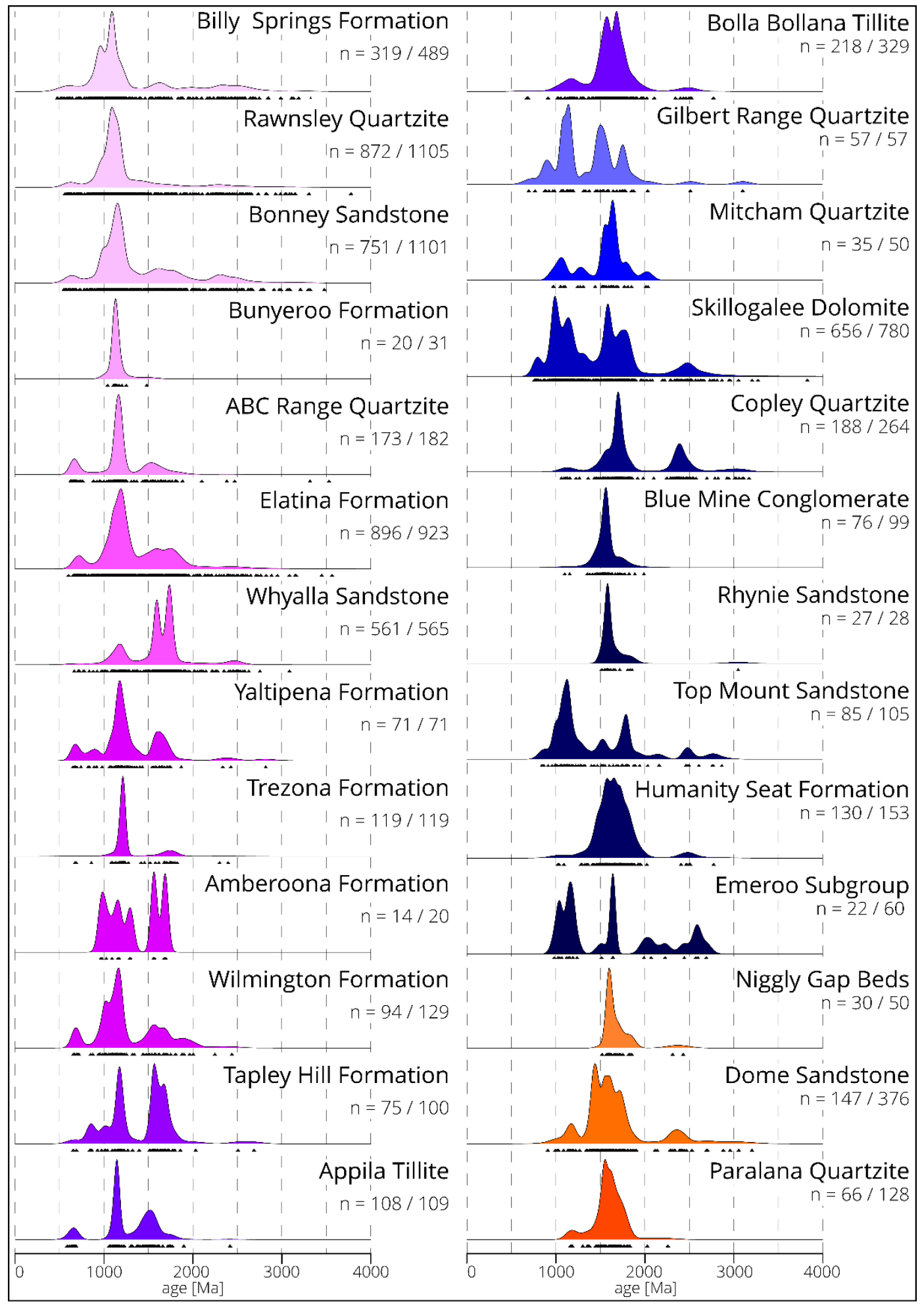

Figure 8 - Kernel density estimates (KDEs) for all data presented in this publication, grouped by formation. These KDEs contain filtered data (based on concordance and relative error) only with the Recovery Formation being omitted due to only having two analyses within the filtering parameters. The markers below each KDE represent the individual data points. For details on the filtering parameters see section 3.3. The KDEs are arranged in stratigraphic order with the Paralana Quartzite being the oldest and the Billy Springs Formation 
This accepted manuscript is a post-print version made available as per Elsevier's sharing policy under a CC-BY-NC-ND license. The final peer reviewed publication in Precambrian Research can be found at https://doi.org/10.1016/i.precamres.2020.105849

407

408

409

410

411

412

413

414

\subsection{Callanna Group}

\subsubsection{Paralana Quartzite}

Samples for the Paralana Quartzite come from Job (2011) (ARK002) and Mackay (2011) (PQ1) [Figure 4]. The $66 / 128$ filtered zircons range from $2259 \pm 25$ Ma to $1164 \pm 52$ Ma with a bimodal major population peak ca. 1600-1560 Ma tailing toward $1800 \mathrm{Ma}$, a minor peak at ca. $1170 \mathrm{Ma}$, scattered ages between 1500$1300 \mathrm{Ma}$, and two analyses over ca. $1830 \mathrm{Ma}$ at $2259 \pm 25 \mathrm{Ma}$ and $2027 \pm 54 \mathrm{Ma}$.

\subsubsection{Dome Sandstone}

The five samples (DS1-DS5) [Figure 4] for the Dome Sandstone come from Mackay (2011). The 147/376 filtered zircons range between $3204 \pm 33 \mathrm{Ma}$ and $908 \pm 72$ Ma with major population peaks at ca. $1720 \mathrm{Ma}$, 1600-1560 Ma, and $1440 \mathrm{Ma}$. There are two minor peaks at ca. $2370 \mathrm{Ma}$ and ca. $1170 \mathrm{Ma}$, the latter tailing toward ca. $1000 \mathrm{Ma}$. There are scattered zircon ages between these populations and above ca. 2500 Ma with three zircons ca. 3000 Ma.

\subsubsection{Recovery Formation}

While Mackay (2011) report only 14 rejected analyses from the total 72 for sample REC1, our filtering parameters yield only two filtered analyses with ages of $924 \pm 52 \mathrm{Ma}$ and $770 \pm 22 \mathrm{Ma}$.

\subsubsection{Niggly Gap Beds}

Data for the Niggly Gap Beds come from one sample published by Ireland et al. (1998) (Ireland98_A) [Figure 4]. The $30 / 50$ filtered zircon analyses range in age between $2431 \pm 22 \mathrm{Ma}$ and $1520 \pm 24 \mathrm{Ma}$, with one major population peak at ca. 1600 Ma tailing toward a minor peak at ca. 1800 Ma. There are two zircons above ca. $1850 \mathrm{Ma}$ at $2431 \pm 22 \mathrm{Ma}$ and $2312 \pm 26 \mathrm{Ma}$.

\section{2. $\quad$ Burra Group}

\subsubsection{Emeroo Subgroup (undifferentiated)}

Sample B2 [Figure 4] of Mackay (2011) is described as coming from the base of the Emeroo Subgroup in the Willouran Ranges. The 22/60 filtered zircon ages range between $2691 \pm 22$ Ma and $982 \pm 8$ Ma with peaks ca. 2480 Ma, ca. $1570 \mathrm{Ma}$, ca. $1110 \mathrm{Ma}$, and ca. $1000 \mathrm{Ma}$. 
This accepted manuscript is a post-print version made available as per Elsevier's sharing policy under a CC-BY-NC-ND license. The final peer reviewed publication in Precambrian Research can be found at https://doi.org/10.1016/i.precamres.2020.105849

\subsubsection{Humanity Seat Formation}

Samples from the Humanity Seat Formation come from Job (2011) (ARK004) and Mackay (2011) (HSF3)

[Figure 4]. There are 130/153 filtered ages for the Humanity Seat Formation ranging between $2775 \pm 25 \mathrm{Ma}$ and $1022 \pm 17 \mathrm{Ma}$. There is a major bimodal population between ca. $1580 \mathrm{Ma}$ and ca. 1500 Ma with a slight tail toward ca. 1800 Ma. Minor populations are present ca. 2400 Ma and ca. 1050 Ma.

\subsubsection{Top Mount Sandstone}

Sample WR37 is a new sample published in this study and comes from the Top Mount Sandstone of the Willouran Ranges [Figure 1, Figure 4]. The 85/105 filtered zircon ages range between $2867 \pm 27 \mathrm{Ma}$ and 841 $\pm 21 \mathrm{Ma}$, with major population peaks at ca. $1800 \mathrm{Ma}$ and ca. $1080 \mathrm{Ma}$. Minor peaks are present at ca. 2480 Ma, and ca. 1530 Ma with scattered zircon ages between these populations and above ca. 2500 Ma.

\subsubsection{Rhynie Sandstone}

The Rhynie Sandstone data come from a single sample published by Gehrels et al. (1996)

(Gehrels96_Rhynie) [Figure 4]. The 27/28 filtered ages range from $3050 \pm 4$ Ma to $1512 \pm 10$ Ma and form an almost exclusive peak ca. 1600 Ma tailing toward ca. 1800 Ma with just one zircon older than ca. 1850 Ma.

\subsection{5. $\quad$ Blue Mine Conglomerate}

Sample ARK005 (Job 2011) [Figure 4] is the only sample from the Blue Mine Conglomerate. The 76/99 filtered zircon ages range between $1990 \pm 27 \mathrm{Ma}$ and $1099 \pm 30 \mathrm{Ma}$ forming one major peak ca. $1580 \mathrm{Ma}$ and a minor peak ca. 1730 Ma.

\subsubsection{Copley Quartzite}

Drabsch (2016) collected four samples of the Copley Quartzite, W16-02, W16-04, W16-05, and W16-11, from the Willouran Ranges [Figure 1, Figure 4]. The 188/264 filtered zircon ages range between $3172 \pm 26$ Ma and $1062 \pm 22$ Ma forming major population peaks at ca. $2400 \mathrm{Ma}$ and ca. $1700 \mathrm{Ma}$, with minor populations at ca. $3000 \mathrm{Ma}$, ca. $1580 \mathrm{Ma}$ tailing toward $1500 \mathrm{Ma}$, and ca. $1100 \mathrm{Ma}$. 
This accepted manuscript is a post-print version made available as per Elsevier's sharing policy under a CC-BY-NC-ND license. The final peer reviewed publication in Precambrian Research can be found at https://doi.org/10.1016/i.precamres.2020.105849

456

457

458

459

460

461

462

463

464

\subsubsection{Skillogalee Dolomite}

Data for four samples, W16-01 (Drabsch 2016), B4 (Mackay 2011), R1675131 and R1675132 (Preiss et al. 2009) are available in existing literature [Figure 4]. In total we publish another six samples, from the Arkaroola area (2116087, 2116090, and 2116094) and Willouran Ranges (WR25, WR26, and WR29) [Figure 4]. The $656 / 780$ filtered zircon ages range between $3825 \pm 20 \mathrm{Ma}$ and $754 \pm 22 \mathrm{Ma}$ forming two major bimodal populations at ca. $1760 \mathrm{Ma} / 1580 \mathrm{Ma}$ and ca. $1140 \mathrm{Ma} / 1000 \mathrm{Ma}$ and minor population peaks at ca. $795 \mathrm{Ma}$ and ca. $2480 \mathrm{Ma}$. It is worthwhile noting the spatial variation of these samples as the oldest grains mostly come from the northern regions of the ARC and the majority of the zircons with ages $<800 \mathrm{Ma}$ come from the central part of the ARC. The oldest zircon in this study, $3825 \pm 20 \mathrm{Ma}$ is found in sample W16-01.

\subsubsection{Mitcham Quartzite}

The Mitcham Quartzite data comes from one sample published by Ireland et al. (1998) (Ireland98_B) [Figure 4]. The 35/50 filtered zircon ages range between $2035 \pm 38$ Ma and $967 \pm 26$ Ma with a bimodal major population peak at ca. 1630 Ma/1560 Ma. Minor zircon populations are present at ca. 2000 Ma, ca. 1280 Ma, and ca. $1080 \mathrm{Ma}$.

\subsubsection{Gilbert Range Quartzite}

Data for the Gilbert Range Quartzite was recently published by Keeman et al. (2020) (Keemana2020_GRQ)

[Figure 4]. We obtain 57/57 filtered zircon ages of the same age range between ca. $3100 \mathrm{Ma}$ and ca. $700 \mathrm{Ma}$ as those authors. Major zircon age populations are present at ca. $1740 \mathrm{Ma}$, ca. $1500 \mathrm{Ma}$, ca. $1140 \mathrm{Ma}$, and ca. 1080 Ma. A minor population is present ca. 890 Ma.

\subsection{Umberatana Group}

\subsubsection{Bolla Bollana Tillite}

Four samples (W16-6, W16-7, W16-8, and W16-9) of Bolla Bollana Tillite were acquired from the Willouran Ranges and analysed by (Shahin 2016) [Figure 1, Figure 4]. The 218/329 filtered zircon ages range between $2771 \pm 63 \mathrm{Ma}$ and $673 \pm 19 \mathrm{Ma}$, with major population peaks at ca. $1680 \mathrm{Ma}$ and ca. $1580 \mathrm{Ma}$. Minor populations are present ca. $2500 \mathrm{Ma}$ and ca. $1180 \mathrm{Ma}$. 
This accepted manuscript is a post-print version made available as per Elsevier's sharing policy under a CC-BY-NC-ND license. The final peer reviewed publication in Precambrian Research can be found at https://doi.org/10.1016/i.precamres.2020.105849

481

482

483

\subsubsection{Appila Tillite}

Data for the Appila Tillite, sampled in the South Flinders Ranges, were recently published by Keeman et al. (2020) [Figure 4]. We corroborate their results with the same 108/109 filtered zircon ages with ages ranging between $2418 \pm 26 \mathrm{Ma}$ and $587 \pm 16 \mathrm{Ma}$. Ages younger than $\sim 660 \mathrm{Ma}$ are unexpected and likely have suffered from some alteration to the geochronometric systems, with all ages younger than this showing moderate levels of discordance when taking the ${ }^{207} \mathrm{~Pb} /{ }^{206} \mathrm{~Pb}$ age into account. There are major age populations ca. $1520 \mathrm{Ma}$ and ca. $1140 \mathrm{Ma}$, with a minor population ca. $660 \mathrm{Ma}$. There is a large break in the population spectra between ca. $1060 \mathrm{Ma}$ and ca. $680 \mathrm{Ma}$. Only one zircon has an age greater than ca. 1900 Ma.

\subsubsection{Tapley Hill Formation}

Sample W16-10 [Figure 4] of Shahin (2016) was erroneously published as part of the Bolla Bollana Tillite in Cox et al. (2018). The 75/100 filtered zircon ages range between $2687 \pm 50 \mathrm{Ma}$ and $654 \pm 13 \mathrm{Ma}$ forming major population peaks at ca. $1680 \mathrm{Ma}$, ca. $1560 \mathrm{Ma}$, and ca. $1180 \mathrm{Ma}$ and two minor peaks at ca. $1020 \mathrm{Ma}$ and ca. $850 \mathrm{Ma}$. Only three zircons have ages greater ca. $1860 \mathrm{Ma}$ and only two have ages less than ca. 840 Ma.

\subsubsection{Amberoona Formation}

WR17 [Figure 4] is a new sample published in this study collected within the Willouran Ranges from the Amberoona Formation. It had a low zircon yield resulting in only 14/20 filtered zircon ages ranging between $1695 \pm 19 \mathrm{Ma}$ and $964 \pm 9 \mathrm{Ma}$. Five populations are present within this limited data at ca. $1690 \mathrm{Ma}$, ca. 1560 Ma, ca. 1300 Ma, ca. 1160 Ma, and ca. 970 Ma.

\subsubsection{Wilmington Formation}

Data for the Wilmington Formation come from two samples. One sample was published by Ireland et al. (1998) (Ireland98_C) from the Marino Arkose member of the Wilmington Formation sampled near Hallett Cove in Adelaide, and the second is a new sample (PR5) sampled from Pichi Richi Pass [Figure 1, Figure 4]. The 94/129 filtered zircon ages range between $2438 \pm 23$ Ma and $655 \pm 34$ Ma, with major population peaks at ca. $1160 \mathrm{Ma}$ and ca. $1030 \mathrm{Ma}$. Minor population peaks of zircon ages occur at ca. $1880 \mathrm{Ma}$, ca. $1680 \mathrm{Ma}$, 
This accepted manuscript is a post-print version made available as per Elsevier's sharing policy under a CC-BY-NC-ND license. The final peer reviewed publication in Precambrian Research can be found at https://doi.org/10.1016/j.precamres.2020.105849

ca. $1570 \mathrm{Ma}$, and ca. $670 \mathrm{Ma}$. Only two zircon ages are greater than ca. $2000 \mathrm{Ma}$.

\subsubsection{Trezona Formation}

Rose et al. (2013) published one sample from the Trezona Formation (CR-09) in the North Flinders Ranges

510 [Figure 1, Figure 4]. The 119/119 filtered zircon ages range from $2396 \pm 10 \mathrm{Ma}$ to $674 \pm 11 \mathrm{Ma}$, with a major peak at ca. $1200 \mathrm{Ma}$ and minor population at ca. $1740 \mathrm{Ma}$.

\subsubsection{Yaltipena Formation}

513 Rose et al. (2013) published one sample from the Yaltipena Formation (CR-04) in the South Flinders Ranges

514 [Figure 1, Figure 4]. The 71/71 filtered zircon ages range between $2818 \pm 10 \mathrm{Ma}$ and $652 \pm 13 \mathrm{Ma}$ with major 515 population peaks at ca. $1620 \mathrm{Ma}$ and ca. $1180 \mathrm{Ma}$, and minor population peaks at ca. $885 \mathrm{Ma}$ and ca. 680

516 Ma. There are only three zircon ages greater than 2000 Ma. Only two zircons have ages greater than ca. 1820 517 Ma and only three are younger than ca. 1080 Ma.

\section{4.3.8. Whyalla Sandstone}

519 Five samples from three locations (CR-12, CR-13 and CR-14) were published by Rose et al. (2013) from the 520 Whyalla Sandstone of the Stuart Shelf [Figure 3, Figure 4]. The 561/565 filtered zircon ages range from 3061 $521 \pm 46 \mathrm{Ma}$ to $641 \pm 6 \mathrm{Ma}$, with major population peaks at ca. $1740 \mathrm{Ma}$ and ca. $1590 \mathrm{Ma}$, and a minor 522 population peak at 1180 Ma. There is also a small population of zircon ages at ca. 2480 Ma.

\section{4.3.9. Elatina Formation}

524 There are twelve published samples from across the ARC for the Elatina Formation. Gehrels et al. (1996) 525 published data for one sample (Gehrels96_Rhynie) from the South Flinders Ranges. Rose et al. (2013) 526 published eleven samples from the South Mount Lofty Ranges (CR-HC), the South Flinders Ranges (CR527 01/Aus01, CR-01/C326-0.0, CR-02/Aus06, CR-03/Aus01, CR-03/Aus02, and CR-05/Aus10) and the North 528 Flinders Ranges (CR-06/Aus11, CR-07/Aus12, CR-08/Aus07, CR-09/C335-31.5, CR-09/C334-560.5, 529 CR10/Aus09, and CR11/Aus08) [Figure 4]. We add an additional two new samples from Pichi Richi Pass (PR1 530 and PR3) bringing the total to fourteen samples with a large spatial variation. The $869 / 923$ filtered zircon 531 ages range from $3564 \pm 24$ Ma to $601 \pm 14$ Ma with a primary population peak of ca. 1180 Ma. There are 532 secondary population peaks ca. $1780 \mathrm{Ma}$, ca. $1600 \mathrm{Ma}$, and ca. $770 \mathrm{Ma}$. The third oldest zircon in this study, 
This accepted manuscript is a post-print version made available as per Elsevier's sharing policy under a CC-BY-NC-ND license. The final peer reviewed publication in Precambrian Research can be found at https://doi.org/10.1016/i.precamres.2020.105849

\section{4.4. Wilpena Group}

\subsubsection{ABC Range Quartzite}

536 The detrital zircon data for the ABC Range Quartzite come from one recently published sample from Keeman et al. (2020) (Keeman2020_ABC) and one new sample, PR4. Both samples are from Pichi Richi Pass in the

538 South Flinders Ranges [Figure 1, Figure 4]. The 173/182 filtered zircon ages range from $3530 \pm 64$ Ma to 622

$539 \pm 24$ Ma with a major population peak at ca. $1170 \mathrm{Ma}$ and minor population peaks at ca. $1560 \mathrm{Ma}$ and ca.

$540680 \mathrm{Ma}$. Two zircons are older than $3300 \mathrm{Ma}$, with a total of five zircons having ages older than ca. $1880 \mathrm{Ma}$.

541 The fourth oldest zircon in this dataset, $3530 \pm 64 \mathrm{Ma}$ is found in sample Keeman2020_ABC.

\section{4.4.2. Bunyeroo Formation}

543 Data for the Bunyeroo Formation are from two samples (WH10, WH127) in the North Flinders Ranges 544 published by Gostin et al. (1986) [Figure 1, Figure 4]. The 20/31 filtered zircon ages range between $1481 \pm$ $54536 \mathrm{Ma}$ and $1041 \pm 26$ Ma with a single population peak ca. $1130 \mathrm{Ma}$.

\section{$546 \quad$ 4.4.3. Bonney Sandstone}

547 Ireland et al. (1998) published one sample (Ireland98_D) from the Bonney Sandstone sampled in the South 548 Flinders Ranges. We publish an additional five samples for the Bonney Sandstone from the South Flinders 549 Ranges (PR6) and North Flinders Ranges (MWH, MWTT, CRI, and BG375) [Figure 1, Figure 4]. The 751/1101 550 filtered zircon ages range from $3477 \pm 32$ Ma to $547 \pm 21$ Ma with major zircon age populations at ca. 1160 551 Ma and ca. 1000 Ma. Broad minor zircon age population peaks are present at ca. 2300 Ma, ca. 1780 Ma, ca. $5521620 \mathrm{Ma}$, and ca. $640 \mathrm{Ma}$.

\section{$553 \quad$ 4.4.4. Rawnsley Quartzite}

554 Data for the Rawnsley Quartzite come from one sample (Keeman_RQ) in the South Flinders Ranges (Keeman 555 et al. 2020 ) [Figure 1, Figure 4], and four new samples published in this study coming from the North 556 Flinders Ranges (CRR, BG378, and 319) and the South Flinders Ranges (PR2) [Figure 4]. The 872/1105 557 filtered zircon ages range from $3778 \pm 45$ Ma to $561 \pm 15$ Ma with a major population peak ca. 1080 Ma. This 
This accepted manuscript is a post-print version made available as per Elsevier's sharing policy under a CC-BY-NC-ND license. The final peer reviewed publication in Precambrian Research can be found at https://doi.org/10.1016/i.precamres.2020.105849

peak population is skewed toward ca. $1180 \mathrm{Ma}$, however, upon close observation there appear to be second concealed major peak ca. $1000 \mathrm{Ma}$. Broad minor population peaks are present at ca. $2300 \mathrm{Ma}$, ca $1400 \mathrm{Ma}$, and ca. $620 \mathrm{Ma}$. The second oldest zircon in this study, $3778 \pm 45 \mathrm{Ma}$, is found in sample CRR.

\subsubsection{Billy Springs Formation}

One new sample, 58 [Figure 4], was sampled in the North Flinders Ranges from the Billy Springs Formation, the stratigraphically youngest Neoproterozoic Formation of the ARC. The 319/489 filtered zircon ages range from $3324 \pm 25$ Ma to $474 \pm 11 \mathrm{Ma}$. Ages younger than ca. $540 \mathrm{Ma}$ are unexpected and are all relatively discordant when considering the ${ }^{207} \mathrm{~Pb} / 206 \mathrm{~Pb}$ age, while being on the limits of concordance $( \pm 10 \%)$ using the ${ }^{206} \mathrm{~Pb} /{ }^{235} \mathrm{U}$ and ${ }^{207} \mathrm{~Pb} / 238 \mathrm{U}$ ages. Thus, we consider these ages younger than ca. $540 \mathrm{Ma}$ to be unreliable, and that the older ${ }^{207} \mathrm{~Pb} /{ }^{206} \mathrm{~Pb}$ are more accurate ages for these zircons. Major zircon age population peaks are at ca. $1090 \mathrm{Ma}$ and ca. $980 \mathrm{Ma}$, with broad minor peaks present at ca. 2500-2400 Ma, ca. $2000 \mathrm{Ma}$, ca. 1620 Ma, and ca. $590 \mathrm{Ma}$.

\section{Discussion}

\subsection{Depositional Age Constraints}

This section first reviews the geochronological research, to date of publication, relevant to constraining the depositional age of Neoproterozoic formations within the Adelaide Superbasin. The appropriate raw data from published articles and theses are combined with new unpublished data and viewed as one dataset. From this large dataset we interpret maximum depositional ages for each formation using the methodology described in section 3.3.

\subsubsection{Igneous Geochronology}

To date there are only two published tuff ages that provide precise absolute age constraints on deposition within the Neoproterozoic of the Adelaide Superbasin. These sit within the Rook Tuff of the Willouran Ranges [Figure 1], $802 \pm 10 \mathrm{Ma}$ (Fanning et al. 1986) (zircon U-Pb SHRIMP), and the Wilyerpa Formation, $663.03 \pm$ $0.11 \mathrm{Ma}$ (Cox et al. 2018) (zircon U-Pb CA-ID-TIMS) of the North Flinders Ranges [Figure 1], which was initially identified and dated by Fanning and Link (2006) who produced an age of ca. $658 \mathrm{Ma}$. These two 
This accepted manuscript is a post-print version made available as per Elsevier's sharing policy under a CC-BY-NC-ND license. The final peer reviewed publication in Precambrian Research can be found at https://doi.org/10.1016/i.precamres.2020.105849

points ( $802 \pm 10 \mathrm{Ma} \& 663.03 \pm 0.11 \mathrm{Ma}$ ) constrain the basal formations of the Curdimurka Subgroup and the top formation of the Yudnamutana Subgroup, respectively.

In the Adelaide area of the South Mount Lofty Ranges [Figure 1], two granitic gneisses were sampled for geochronology by Preiss et al. (2008). Originally thought to be related to the Delamerian Orogeny, the Mount Crawford Granite Gneiss (Mills 1963), and the Oakbank Inlier Granitic Gneiss, yielded magmatic crystallisation ages of $812 \pm 6 \mathrm{Ma}$ and $856 \pm 20 \mathrm{Ma}$ for the precursor granites of each respectively. These present useful constraints on the maximum possible age of deposition for the rocks in the Adelaide area of the Adelaide Superbasin. The oldest known rock in the Adelaide Superbasin from this area, the Aldgate Sandstone, is interpreted to be at the base of the Burra Group and unconformably overlies the Mount Crawford Granite Gneiss.

The Kooringa Member of the Skillogalee Dolomite contains syn-depositional volcanism, and a penecontemporaneous felsic porphyry that has been described as cross-cutting the member. Preiss et al. (2009) performed U-Pb LA-ICP-MS analysis on zircon from both the volcaniclastic siltstone of the Kooringa Member and the cross-cutting felsic porphyry yielding ages of $787 \pm 6$ Ma and $794 \pm 4$ Ma respectively, those authors quoted a minimum depositional age of ca. 790 Ma due to the conflicting ages. The exact relationship of this cross-cutting porphyry to the volcaniclastic siltstone within the Kooringa Member is not well explained in Preiss et al. (2009), Drexel (2009) or Drexel and McCallum (1986) and revisiting the site to view the relationship is not possible as the samples are from the Burra copper mine, which is now flooded.

Other igneous ages that may constrain the timing of deposition exist; however, due to uncertainty in stratigraphic relationships, large analytical uncertainty, or their unpublished nature, these are considered less reliable than the previously described ages. These are described in the following paragraphs.

The Wooltana Volcanics of the Arkaroola area [Figure 1] have been dated using Rb-Sr whole rock, which yield an age of $830 \pm 50 \mathrm{Ma}$, recalculated in Preiss (2000) from Compston et al. (1966). This isochron age has a large uncertainty. Further, the Wooltana Volcanics are unconformably overlain by the Burra Group, with the entire Curdimurka Subgroup not deposited in the Arkaroola area, suggesting a depositional hiatus in the region (Preiss 1987). Other areas of the Adelaide Superbasin have volcanic rocks that are correlated with the 
This accepted manuscript is a post-print version made available as per Elsevier's sharing policy under a CC-BY-NC-ND license. The final peer reviewed publication in Precambrian Research can be found at https://doi.org/10.1016/i.precamres.2020.105849

609 Wooltana Volcanics as part of the Willouran Basic Province (Hillyard 1990). These include the Noranda 610 Volcanics, the Cadlareena Volcanics, the Beda Basalt (Wade, CE et al. 2014), the Willangee Basalt, volcanic clasts within diapiric breccia, and the 'Depot Creek Volcanics', all of which are suggested as coeval to the

Gairdner Dolerite, $826 \pm 7$ Ma (Wingate et al. 1998), and the "Little Broken Hill gabbro", $827 \pm 9$ Ma (Wingate et al. 1998), of the Gairdner Dyke Swarm (GDS). The correlative Gairdner Dolerite age of ca. 827 Ma has

614 recently been quoted as the age of the Wooltana Volcanics (Hore 2015; Keeman et al. 2020; Mackay 2011).

615 While there is little doubt that this association is reasonable, it does not provide a direct age of the Wooltana

616 Volcanics and associated formations of the Willouran Basic Province. Initial correlation of the Gairdner

617 Dolerite to the Willouran Basic Province was based on an unpublished age from the Boucaut Volcanics by the 618 upper intercept of its uncertainty (Drexel et al. 1993). This correlation with the Boucaut Volcanics has since 619 proven to be incorrect and is discussed later in this section. In our view, the Rb-Sr age of $830 \pm 50 \mathrm{Ma}$ 620 should be used for the Wooltana Volcanics, sensu stricto, until a more reliable age can be obtained.

621 The most dependable of the additional igneous ages is that of the Oodla Wirra Volcanics within the Nackara 622 Arc [Figure 1]. Two SHRIMP U-Pb concordia ages were obtained for the Oodla Wirra Volcanics, $798 \pm 5 \mathrm{Ma}$ 623 and $799 \pm 4 \mathrm{Ma}$ (Fabris et al. 2005), making it coeval the Rook Tuff at $802 \pm 10 \mathrm{Ma}$ (Fanning et al. 1986). 624 However, stratigraphic relationships are difficult to determine as no contact relationships with intact stratigraphy are observed in the field, with further field evidence suggesting that the volcanic units are blocks within a diapiric breccia (Fabris et al. 2005). Alongside petrological analysis revealing evaporite mineralogy, the two SHRIMP ages suggest that the Oodla Wirra Volcanics belong to the Curdimurka Subgroup and are equivalent to the Rook Tuff.

629 A third available dated igneous formation is the Boucaut Volcanics of the Nackara Arc [Figure 1]. Initially this 630 formation was thought to be a stratigraphic equivalent to the Wooltana Volcanics and led to its correlation 631 with the GDS (Wingate et al. 1998). Although the overall correlation of the GDS to the Wooltana Volcanics 632 seems to remain true, the specific correlation of the Boucaut Volcanics to the Gairdner Dolerite and 633 Wooltana Volcanics does not hold true. The stratigraphic relationship of the silicic Boucaut Volcanics still 634 remains difficult to determine but is currently considered to be within the basal Burra Group, within or below 
This accepted manuscript is a post-print version made available as per Elsevier's sharing policy under a CC-BY-NC-ND license. The final peer reviewed publication in Precambrian Research can be found at https://doi.org/10.1016/i.precamres.2020.105849

the Rhynie Sandstone (Preiss 2000). Two ages for the Boucaut Volcanics are mentioned in literature, $783 \pm$

$42 \mathrm{Ma}$ (Drexel et al. 1993) and $777 \pm 7$ Ma cited in Preiss (2000). However, both ages have never been

formally published with verifiable results. More recent analysis of the Boucaut Volcanics via U-Pb LA-ICP-MS on zircon is yet to be published but yields an age ca. $788 \mathrm{Ma}$ (Armistead et al. in prep, pers comms). This is an important age as it potentially constrains the base of the Burra Group thereby providing minimum age for the division of the syn-rift evaporitic clastic, carbonate sediments, and volcanic lithologies of the Callanna Group from the proximal marine to marine formations of the overlying Burra Group. Current geochronology suggests that the Boucaut Volcanics are equivalent to the volcanics within the Kooringa Member of the Skillogalee Dolomite and would therefore constrain the basal formations of the Mundallio Subgroup. An alternative explanation is that the Boucaut Volcanics are indeed at the base of or within the Rhynie Sandstone as is currently considered. However, this would require a compression of stratigraphy and revision of the Emeroo and Mundallio Subgroups. Detailed mapping of the type-section area is required to clarify the exact stratigraphic position of the Boucaut Volcanics. High precision CA-ID-TIMS geochronology of the Kooringa Member, Boucaut Volcanics, Rook Tuff and Oodla Wirra Volcanics would prove fruitful in identifying their true chronological relationships to each other.

A rhyolite in the Mount Arrowsmith Volcanics, which form a younger silicic igneous formation within the Koonenberry Belt [Figure 1] (New South Wales), has been dated by SHRIMP U-Pb zircon at $585.5 \pm 3.2 \mathrm{Ma}$ (Black 2007). This provides an excellent constraint within the Neoproterozoic-Cambrian Kara Formation of the Grey Range Group. The Grey Range Group is interpreted as the stratigraphic equivalent of the Farnell Group (Greenfield \& Mills 2010), the uppermost division of the New South Wales component of the Adelaide Supergroup (Cooper, PF et al. 1974). The correlation to the South Australian Adelaidean sequences was last updated in Sheibner and Basden (1998) based upon the prior literature, however, this literature includes now superseded stratigraphic grouping and nomenclature. The Mount Arrowsmith Volcanics are tentatively correlated to the position of the Aruhna Subgroup within the Wilpena Group in the South Australian portion of the Adelaide Superbasin. This correlation is based upon the age of the Yarloo Shale described later in section 5.1.2, and research of stratigraphic relationships based on previous literature (Cooper, PF et al. 
This accepted manuscript is a post-print version made available as per Elsevier's sharing policy under a CC-BY-NC-ND license. The final peer reviewed publication in Precambrian Research can be found at https://doi.org/10.1016/i.precamres.2020.105849

661 1974; Drexel et al. 1993; Powell et al. 1994; Preiss 1987; Preiss \& Cowley 1999; Preiss et al. 1998; and

662 references therein). The age of the Mount Arrowsmith Volcanics is not presented in Figure 6, Figure 7, or

663 Table 2 due to uncertainty in the correlation at this stage; however, a detailed, updated stratigraphic

664 correlation of the Adelaidean system for South Australia and New South Wales is linked in Data Availability.

665 There have been other attempts at dating the basic igneous formations of the Adelaide Superbasin, with little 666 success. The Beda Volcanics of the Stuart Shelf, now Beda Basalt (Wade, CE et al. 2014), has yielded Rb-Sr 667 whole rock isochron ages of $697 \pm 70$ Ma (Webb \& Hörr 1978) and later $1076 \pm 34$ Ma (Webb \& Coats 1980). 668 Webb and Coats (1980) discounted the younger age based on Rb-Sr whole rock isochron ages of the Tapley 669 Hill Formation and the now superseded 'Willochra Subgroup' (the Upalinna and Yerelina subgroups contain 670 what was the Willochra) that both overlie the Beda Basalt. However, the isochron ages for the Tapley Hill 671 Formation and 'Willochra Subgroup' themselves are now considered inaccurate as is discussed later in 672 section 5.1.2. Neither of the ages for the Beda Basalt have been substantiated. Significant doubts about 673 these ages exist because of the strong geochemical and petrological affinities to the other basic volcanics of 674 the Willouran Basic Province (Crawford \& Hillyard 1990; Gum 1987; Hillyard 1990; Wade, CE et al. 2014; 675 Woodget 1987) and thus the uncertainty regarding the accuracy of these ages forces us to consider them 676 unreliable.

677 The early Cambrian Heatherdale Shale of the Normanville Group within the South Mount Lofty Ranges [Figure 678 1] contains a tuff that was analysed via U-Pb SHRIMP yielding a zircon age of $526 \pm 4 \mathrm{Ma}$ (Cooper, JA et al. 679 1992), this was later revised to $522 \pm 2 \mathrm{Ma}$ (Jenkins et al. 2002), and then subsequently to $514.98 \pm 0.22$ 680 Ma (Betts et al. 2018), providing an absolute minimum age for deposition of the Heysen Supergroup in the 681 southern Adelaide Superbasin. The Heatherdale Shale lies at the top of the Normanville Group, and as such 682 the actual minimum age for deposition the Heysen Supergroup is likely much older than $514 \pm 0.22$ Ma and 683 is consistent with the palaeontological data (Betts et al. 2018; Jenkins et al. 2002). In addition, Betts et al. 684 (2018) determined zircon TIMS ages of $515.38 \pm 0.13 \mathrm{Ma}, 514.56 \pm 0.13 \mathrm{Ma}$, and $514.46 \pm 0.13 \mathrm{Ma}$, from 685 three tuffs in the stratigraphically equivalent Mernmerna Formation of the Arrowie Basin.

686 The advancement of modern geochronological techniques, an improved understanding of geochronological 
This accepted manuscript is a post-print version made available as per Elsevier's sharing policy under a CC-BY-NC-ND license. The final peer reviewed publication in Precambrian Research can be found at https://doi.org/10.1016/j.precamres.2020.105849

systems, and the discovery of small intermediate to felsic volcanic sequences may provide a significantly

greater understanding of the absolute geochronological constraints of the Adelaide Superbasin in the future.

\subsubsection{Other Geochronological Techniques}

690 There have been several attempts to date sedimentary rocks of the Adelaide Superbasin via whole rock methods with varying success. The oldest formation for which this has been attempted is the Tapley Hill

692 Formation of the Nepouie Subgroup, Umberatana Group. Webb and Coats (1980) analysed samples of Tapley 693 Hill Formation and Willochra Subgroup from the Stuart Shelf via Rb-Sr whole rock geochronology, yielding 694 isochron ages of $750 \pm 53 \mathrm{Ma}$ and $724 \pm 40 \mathrm{Ma}$, respectively. The $724 \pm 40 \mathrm{Ma}$ age was altered by Webb et 695 al. (1983) with the addition of a sixth Rb-Sr whole rock sample to $686 \pm 59$ Ma. However, Webb et al. (1983) 696 noted that the sixth sample was lithologically different from the original five and the legitimacy of its 697 inclusion was questioned. More recent work by Kendall et al. (2006) using Re-Os whole rock geochronology 698 on black shales of the Tindelpina Sale Member (basal Tapley Hill Formation) yielded a pooled age of $643 \pm$ 699 2.4 Ma from both the Stuart Shelf $(647 \pm 10 \mathrm{Ma}$ ) and the Adelaide Rift Complex (645.1 $\pm 4.8 \mathrm{Ma})$. Alongside 700 the Rook Tuff age of Fanning et al. (1986), this cast the original ages for the Tapley Hill Formation into doubt. The Re-Os age was suggested to reflect "basin-wide post-depositional homogenization of the Os isotopic composition of the Tindelpina Shale" by Mahan et al. (2010) who obtained an age via Th-U-total Pb age of authigenic monazite of $680 \pm 23$ Ma for the Enorama Shale. The recent age of $663.03 \pm 0.11$ Ma obtained by Cox et al. (2018) for a tuff in the Wilyerpa Formation, which is stratigraphically below the Tapley Hill Formation, confirms that the ca. $750 \mathrm{Ma}$ and ca. $724 \mathrm{Ma}$ ages are indeed inaccurate. It also suggests that the $643 \pm 2.4 \mathrm{Ma}$ (Kendall et al. 2006) Re-Os age is likely to be closer to the true depositional age. However, this Re-Os age would require a significant hiatus or condensation in deposition from the end of the Sturtian Glaciation, ca. $663 \mathrm{Ma}$ (Cox et al. 2018), conflicts with the 657.2 $\pm 5.4 \mathrm{Ma}$ (Kendall et al. 2006) Re-Os whole rock age obtained for the Aralka Formation, a purportedly coeval formation from the Amadeus Basin 710 (Edgoose 2013; Preiss 1987), and conflicts with some estimates for the onset of the Marinoan Glaciation 711 (Hoffman et al. 2017; Rooney et al. 2020). In light of this tuff age, the estimate of minimum depositional age for the Enorama Shale, $680 \pm 23 \mathrm{Ma}$ (Mahan et al. 2010), is also not considered accurate as the Enorama 
This accepted manuscript is a post-print version made available as per Elsevier's sharing policy under a CC-BY-NC-ND license. The final peer reviewed publication in Precambrian Research can be found at https://doi.org/10.1016/i.precamres.2020.105849

713 Shale is positioned stratigraphically above (approximately $3 \mathrm{~km}$ up sequence) the Tindelpina Shale Member 714 and Wilyerpa Formation.

715 Further attempts at other geochronology have had varying success, with Webb et al. (1983) reporting Rb-Sr 716 whole rock isochron ages for the Tregolana Shale Member (prev. Woomera Shale) of the Stuart Shelf, $676 \pm$ $717200 \mathrm{Ma}$, the stratigraphically equivalent Brachina Formation of the Adelaide Rift Complex, $601 \pm 68 \mathrm{Ma}$, and 718 the stratigraphically lower Angepena Formation $618 \pm 136 \mathrm{Ma}$. Compston et al. (1987), later pooled the ages 719 for the Tregolana Shale Member and Brachina Formation to yield an age of $609 \pm 64$ Ma for the Brachina 720 Formation that is broadly supported by more recent geochronological constraints. Compston et al. (1987), 721 also pooled the Angepena Formation age and earlier Tapley Hill Formation (Webb et al. 1983) age to yield an 722 age of $713 \pm 38$ Ma for the middle Umberatana Group. Based upon more recent work and the data presented 723 in this paper, the pooled and individual ages for the Brachina Formation are within uncertainty of the 724 expected depositional age. However, this pooled age is not considered to be useful, as the two formations 725 are not stratigraphic equivalents and the age for the Tapley Hill Formation has been confirmed inaccurate.

726 Haines et al. (2004), undertook a large case study using detrital muscovite in the Adelaide Superbasin for 727 provenance investigations discussed in section 5.2. Aside from two clearly reset samples, most of the 728 detrital muscovite in the samples yielded ages significantly older than inferred depositional ages for the 729 Neoproterozoic sedimentary rocks analysed. Their exception to this was the Bonney Sandstone that yielded 730 a detrital muscovite grain with an age of $601 \pm 17$ Ma, which (Haines et al. 2004) suggested may approach 731 the true age of deposition.

732 An equivalent of the Bunyeroo Formation in the Adelaide Rift Complex is the Yarloo Shale of the Stuart Shelf 733 that yielded a model-3 Rb-Sr isochron age of $588 \pm 35 \mathrm{Ma}$ (Webb 1980) with an MSWD of 8.7. This is a Rb734 Sr whole rock age and was noted by the author that its significance could only be verified by the dating of 735 other rocks from the same stratigraphic level on the Stuart Shelf and it has since been suggested that three 736 of the seven samples making the isochron are from the basal parts of the Wonoka Formation (Compston et 737 al. 1987), nonetheless it provides a guiding constraint where there otherwise would not be one. Modern in738 situ Rb-Sr LA-QQQ-MS and authigenic titanite methods are likely to provide much greater clarification and 
This accepted manuscript is a post-print version made available as per Elsevier's sharing policy under a CC-BY-NC-ND license. The final peer reviewed publication in Precambrian Research can be found at https://doi.org/10.1016/i.precamres.2020.105849

739 accuracy of depositional ages for suitable sedimentary rocks within the Adelaide Superbasin.

\section{5.1.3. Previous Detrital Zircon Geochronology}

741 To date, there have been seven studies that have published detrital zircon data from the Adelaide

742 Superbasin. The first, Compston et al. (1987), undertook a study to show that a particular tuff-like layer in

743 the Bunyeroo Formation was not formed from volcanic detritus contemporaneous with sedimentation, and is

744 actually an ejecta blanket associated with the Acraman impact (Gostin et al. 1986; Williams 1986). Of

745 relevance, this study provides two samples (WH10, WH127, Figure 4) from detrital layers of the Bunyeroo

746 Formation for which they quoted a depositional age of $593 \pm 32 \mathrm{Ma}$. The next study to produce detrital zircon

747 data was conducted almost ten years later by Gehrels et al. (1996) who were investigating the provenance of

748 the Alexander terrane in Alaska. This study published two samples from the Adelaide Superbasin in the

749 Elatina Formation and the Rhynie Sandstone [Figure 4]. Following this, Ireland et al. (1998), undertook a

750 study to investigate the development of the early Palaeozoic Pacific margin of Gondwana using detrital zircon

751 geochronology from samples across the Delamerian Orogen. Ireland et al. (1998) collected nine samples

752 from the Adelaide Superbasin [Figure 4], with four from Neoproterozoic formations; the Niggly Gap Beds, the

753 Mitcham Quartzite, the Marino Arkose Member, and the Bonney Sandstone. No maximum depositional ages

754 were quoted in Gehrels et al. (1996) or Ireland et al. (1998). A further eleven years later Preiss et al. (2009)

755 published their study on the Kooringa Member of the Skillogalee Dolomite in which they defined the member

756 and investigated the age of the host formation of the Burra copper orebody[Figure 1]. This study provided

757 two samples from a volcaniclastic siltstone within the Kooringa Member and a penecontemporaneous

758 porphyry. Rose et al. (2013), conducted a detailed study of the Marinoan glaciation in South Australia

759 producing a highly focussed dataset of 20 samples [Figure 4] from the Trezona Formation, the Yaltipena

760 Formation, the Elatina Formation, and the Whyalla Sandstone. No maximum depositional ages were quoted

761 by Rose et al. (2013). A study investigating the timing of the end of the Sturtian Glaciation by Cox et al.

762 (2018) published a tuff age from the Wilyerpa Formation, that is described earlier in this section, and two

763 detrital samples (W16-09 \& W16-10, Figure 4) from Shahin (2016). One of these samples-W16-10-is

764 erroneously published by Cox et al. (2018) as belonging to the Bolla Bollana Tillite rather than the Tapley Hill 
This accepted manuscript is a post-print version made available as per Elsevier's sharing policy under a CC-BY-NC-ND license. The final peer reviewed publication in Precambrian Research can be found at https://doi.org/10.1016/j.precamres.2020.105849

765 Formation from which it was sampled. The most recent publication on detrital geochronology in the Adelaide

766 Superbasin by Keeman et al. (2020) is a comprehensive study that reprocesses samples from Ireland et al.

767 (1998) and publishes new data from the Gilbert Range Quartzite, Sturt Tillite, Appila Tillite, Brachina

768 Formation, ABC Range Quartzite, Rawnsley Quartzite, and several Cambrian formations. While this study is

769 extensive and provides much needed hafnium isotope data, the supplementary dataset available with the

770 publication is incomplete. Additionally, several detrital zircon studies have been completed as research

771 projects (Drabsch 2016; Job 2011; Shahin 2016; Mackay 2011), adding a significant amount of detrital

772 zircon data that had not yet been formally published.

773 5.1.4. Detrital Zircon Maximum Depositional Ages

774 This section interprets and discusses detrital zircon maximum depositional ages (MDAs) quoted as the 775 preferred MDA from Table 2 for the each of the Neoproterozoic Formations in this study of the Adelaide

776 Superbasin, in stratigraphic order of oldest to youngest, using the combined dataset presented in this paper.

777 The dataset includes legacy and new data and is all subject to the statistical methods outlined in section 3.3.

778 Only the formations from Keeman et al. (2020) with their full data available in their supplementary data are

779 reinterpreted with our methods; these are the Gilbert Range Quartzite, the Appila Tillite, the Bonney

780 Sandstone, and the Rawnsley Quartzite. All other MDAs from Keeman et al. (2020) are taken as is reported

781 by those authors. However, we modify their uncertainty to two standard deviations and quote ages as whole

782 integers. All geochronological constraints, including the MDAs described in this section are summarised in

783 Table 2. Regions highlighted in parentheses after a formation name correspond to the areas outlined in

784 Figure 1.

785 5.1.4.1. Callanna Group

786 Of the 24 sedimentary formations in the Callanna Group only four have detrital zircon U-Pb data. The oldest 787 of these, the Paralana Quartzite, is restricted to the Arkaroola area [Figure 1] and has an MDA of $1177 \pm 28$

788 Ma. This age is significantly older than the expected depositional age of ca. $840 \mathrm{Ma}$ (Powell et al. 1994;

789 Preiss 1987; 2000). The minimum age of deposition for the Arkaroola Subgroup is constrained by the

790 Wooltana Volcanics, $830 \pm 50 \mathrm{Ma}$ (Preiss 2000). There are currently no detrital zircon data from any other 
This accepted manuscript is a post-print version made available as per Elsevier's sharing policy under a CC-BY-NC-ND license. The final peer reviewed publication in Precambrian Research can be found at https://doi.org/10.1016/i.precamres.2020.105849

791 Arkaroola Subgroup or equivalent Pintapah Subgroup (NSW), and Wendalpa Subgroup (NSW) rock. Following 792 this, the Dome Sandstone (Willouran Ranges), the oldest rock of the Curdimurka Subgroup, has an MDA of $793993 \pm 62 \mathrm{Ma}$. This is older than the true depositional age of the Dome Sandstone as the Wooltana Volcanics 794 (corr. Noranda Volcanics, Willouran Ranges) and Rook Tuff provide maximum and minimum limits of 795 deposition at $830 \pm 50 \mathrm{Ma}$ (Preiss 2000) and $802 \pm 10 \mathrm{Ma}$ (Fanning et al. 1986) respectively. The remaining 796 two formations of the Callanna Group with detrital zircon data are the Niggly Gap Beds (North Mount Lofty 797 Ranges) and Recovery Sandstone (Willouran Ranges). The Rook Tuff provides a maximum age constraint of $798802 \pm 10 \mathrm{Ma}$ (Fanning et al. 1986) and the Kooringa Member and Boucaut Volcanics provide a minimum age 799 constraint of ca. 790 Ma (Preiss et al. (2009); Armistead et al. in prep, pers comms) for the Niggly Gap Beds 800 and Recovery Sandstone. The Niggly Gap Beds have an MDA of $1616 \pm 34 \mathrm{Ma}$, well beyond the range for true 801 depositional age. The Recovery Sandstone has no zircon within $2 \%$ of concordance and thus we do not quote 802 an MDA for the formation. There are limited data available for both the Niggly Gap Beds ( $n=30 / 50)$, and 803 Recovery Sandstone ( $n=2 / 71)$. There are currently no detrital zircon data from any other Curdimurka 804 Subgroup rock.

\subsubsection{Burra Group}

Of the 36 named formations within the Burra Group, eight have detrital zircon U-Pb geochronology data. In the South Mount Lofty Ranges [Figure 1] the Burra Group is constrained to a being deposited after $812 \pm 6$ Ma [Figure 6] by the Mount Crawford Granite Gneiss (Preiss et al. 2008) that directly, but unconformably underlies the oldest Burra Group formation in the region. The Emeroo Subgroup is further constrained to a minimum age of ca. 790 Ma by penecontemporaneous volcanism within the Kooringa Member of the 811 Skillogalee Dolomite (Preiss et al. 2009). Within the Emeroo Subgroup there are five named formations with detrital zircon geochronology data. The oldest of the named formations, the Top Mount Sandstone (Willouran 813 Ranges) and correlative Humanity Seat Formation (Arkaroola Area), and Rhynie Sandstone (North Mount 814 Lofty Ranges) have MDAs of $841 \pm 21 \mathrm{Ma}, 1053 \pm 114 \mathrm{Ma}$, and $1513 \pm 26 \mathrm{Ma}$, respectively. The Blue Mine 815 Conglomerate (Arkaroola Area) has an MDA of $1106 \pm 85 \mathrm{Ma}$ and the Copley Quartzite (North Flinders 
This accepted manuscript is a post-print version made available as per Elsevier's sharing policy under a CC-BY-NC-ND license. The final peer reviewed publication in Precambrian Research can be found at https://doi.org/10.1016/i.precamres.2020.105849

depositional age. The three formations with detrital zircon geochronology data in the Burra Group are the

Skillogalee Dolomite, (MDA: $789 \pm 9$ Ma), the Mitcham Quartzite (MDA $1053 \pm 42$ Ma, South Mount Lofty

819 Ranges), and the Gilbert Range Quartzite (MDA $731 \pm 34$ Ma, North Mount Lofty Ranges). The Skillogalee

820 Dolomite MDA is within uncertainty of true depositional age as shown by the age for penecontemporaneous

821 volcanism within the Kooringa Member of the Skillogalee Dolomite, ca. 790 Ma (Preiss et al. 2009). The

822 Mitcham Quartzite MDA is an overestimate of true depositional age and the Gilbert Range Quartzite MDA is

823 likely close to true depositional age (pre-Sturtian Glaciation), with estimates for the onset of the Sturtian

824 Glaciation ca. $715 \mathrm{Ma}$ (Hoffman et al. 2017).

\section{5.1.4.3. Umberatana Group}

826 There are eight formations of the total 38 named formations within the Umberatana Group that have detrital 827 zircon U-Pb geochronology data. The Yudnamutana Subgroup glacial sedimentary rocks are constrained to a 828 minimum age of ca. 663 Ma by a tuff layer within the overlying Wilyerpa Formation (Cox et al. 2018). Detrital 829 zircon data are available from the Bolla Bollana, Sturt and Appila Tillites. The MDA for the Bolla Bollana Tillite 830 (North Flinders Ranges) is $673 \pm 19 \mathrm{Ma}$, this differs from that in Cox et al. (2018) as it excludes sample W1683110 which has been reassessed as being from the lowermost Tapley Hill Formation (Shahin 2016). For the 832 Appila Tillite (South Flinders Ranges), we use the youngest population age of $667 \pm 6 \mathrm{Ma}$, as the youngest 833 single grain is below the minimum constraint provided by the Wilyerpa Tuff and has potentially suffered from 834 modern lead loss, a point also made by Keeman et al. (2020). For the Sturt Tillite we use the MDA quoted by 835 Keeman et al. (2020) of $714 \pm 28 \mathrm{Ma}$ (YSG) as their supplementary data for the Sturt Tillite is incomplete. 836 The MDAs for the Yudanamutana Subgroup glacial rocks are consistent with estimates for the duration of the 837 Sturtian Glaciation ca. 715-660 Ma (Cox et al. 2018; Hoffman et al. 2017; Rooney et al. 2020). The Tapley 838 Hill Formation has an MDA of $654 \pm 13 \mathrm{Ma}$, this is from sample W16-10 of (Shahin 2016) and is consistent 839 with the timing of Sturtian deglaciation. Within the Upalinna Subgroup there are detrital zircon data for the 840 Wilmington Formation, Amberoona Formation, Trezona Formation, and Yaltipena Formation. Respectively, 841 the MDAs of these formations are $688 \pm 8 \mathrm{Ma}, 1110 \pm 71 \mathrm{Ma}, 674 \pm 11 \mathrm{Ma}$, and $662 \pm 20 \mathrm{Ma}$. Keeman et al. 842 (2020) quote a youngest mean weighted age for $654 \pm 13$ Ma for the Marino Arkose Member of the 
This accepted manuscript is a post-print version made available as per Elsevier's sharing policy under a CC-BY-NC-ND license. The final peer reviewed publication in Precambrian Research can be found at https://doi.org/10.1016/j.precamres.2020.105849

843 Wilmington Formation with reprocessed data from Ireland et al. (1998). However, we cannot verify this from

844 their supplementary dataset. With the exception of the Amberoona Formation, MDAs of these Upalinna

845 Subgroup rocks are approaching the estimated true depositional ages as constrained by the Sturtian

846 deglaciation ca. $663 \mathrm{Ma}$ (Cox et al. 2018) and estimated onset of the Marinoan Glaciation ca. 650-640 Ma

847 (Hoffman et al. 2017). The Amberoona Formation only has extremely limited data available $(n=14)$. The

848 remaining two formations of the Umberatana Group with detrital zircon geochronology data are the Elatina

849 Formation (MDA $671 \pm 52 \mathrm{Ma}$ ) and the coeval Whyalla Sandstone (MDA $641 \pm 6 \mathrm{Ma}$ ) of the Stuart Shelf, both

850 are within uncertainty of their expected true depositional ages during the Marinoan glaciation ca. 650-635

851 Ma (Hoffman et al. 2017).

852 5.1.4.4. Wilpena Group

853 Six of the fifteen formations of the Wilpena Group have detrital zircon U-Pb geochronology data. Keeman et

854 al. (2020) quote results from the Brachina Formation, however, these data are missing from their

855 supplementary dataset and no MDA is quoted. The other only other Sandison Subgroup formation with

856 detrital zircon $\mathrm{U}-\mathrm{Pb}$ age data are in the ABC Range Quartzite and has an MDA of $630 \pm 16 \mathrm{Ma}$. The MDA of

857 the ABC Range Quartzite is likely within uncertainty of the true depositional age for this formation and is

858 compatible with estimates for the end of the Marinoan Glaciation at ca. $635 \mathrm{Ma}$ (Hoffman et al. 2017). The

859 Bunyeroo Formation of the Aruhna Subgroup has an MDA of $1041 \pm 26$, significantly older than true

860 depositional age. Limited data $(n=20 / 31)$ available for this formation. In this publication we add a substantial

861 amount (>1000 for each formation) of new data for the Bonney Sandstone and the Rawnsley Quartzite of the

862 Pound Subgroup. The Rawnsley Quartzite is most famously known for the fossils of Ediacara fauna that it

863 preserves (Droser \& Gehling 2015; Gehling \& Droser 2012; Glaessner 1959; Sprigg 1948). Here we quote

864 conservative ages of $579 \pm 32$ Ma and $570 \pm 23$ Ma for the Bonney Sandstone and Rawnsley Quartzite,

865 respectively. The MDA of the Rawnsley Quartzite is within uncertainty, and therefore compatible with

866 estimates for the ages of various Ediacara fauna ca. 575-541 Ma (Grazhdankin 2004). The youngest

867 Neoproterozoic formation of the central Adelaide Rift Complex is the Billy Springs Formation, for which we

868 add a substantial amount of data $(n>300)$ and quote an MDA of $564 \pm 25$ Ma. This is again, likely to be within 
This accepted manuscript is a post-print version made available as per Elsevier's sharing policy under a CC-BY-NC-ND license. The final peer reviewed publication in Precambrian Research can be found at https://doi.org/10.1016/i.precamres.2020.105849

uncertainty of the true depositional age of the formation. 
This accepted manuscript is a post-print version made available as per Elsevier's sharing policy under a CC-BY-NC-ND license. The final peer reviewed publication in Precambrian Research can be found at https://doi.org/10.1016/i.precamres.2020.105849

Table 2 - Summary of Adelaide Superbasin (Neoproterozoic) Geochronology with Maximum Depositional Ages (MDA)

\begin{tabular}{|c|c|c|c|c|c|c|c|c|c|c|c|}
\hline Formation & Region & $\begin{array}{l}\text { n zircon } \\
\text { (filtered) }\end{array}$ & $\begin{array}{l}\text { Auto MDA } \\
\text { (Ma) } \mathrm{YSG}^{\wedge}\end{array}$ & $\begin{array}{l}{ }^{206} \mathrm{~Pb} /{ }^{238} \mathrm{U} \\
\text { Age of YSG } \\
(\mathrm{Ma})\end{array}$ & $\begin{array}{l}{ }^{207} \mathrm{~Pb} /{ }^{235} \mathrm{U} \\
\text { Age of } \\
\text { YSG (Ma) }\end{array}$ & $\begin{array}{l}{ }^{207} \mathrm{~Pb} /{ }^{206} \mathrm{~Pb} \\
\text { Age of YSG } \\
\text { (Ma) }\end{array}$ & $\begin{array}{l}\text { MDA (Ma) } \\
\text { YPA* } \\
\text { (n; MSWD) }\end{array}$ & $\begin{array}{l}\text { Depositional } \\
\text { Age (Ma) (Syn- } \\
\text {, Min.) }\end{array}$ & $\begin{array}{l}\text { Preferred } \\
\text {-MDA }{ }^{\&}(\mathrm{Ma})\end{array}$ & $\begin{array}{l}\text { Geochronology } \\
\text { Method }\end{array}$ & $\begin{array}{l}\text { Original Data } \\
\text { Source }\end{array}$ \\
\hline $\begin{array}{l}\text { Billy Springs } \\
\text { Formation (Npi) }\end{array}$ & $\begin{array}{l}\text { North Flinders } \\
\text { Ranges }\end{array}$ & 319 & $553 \pm 15$ & $553 \pm 15$ & $564 \pm 25$ & $612 \pm 123$ & & & $564 \pm 25$ & $\begin{array}{l}\text { LA-ICP-MS } \\
\text { Detrital Zircon }\end{array}$ & This study \\
\hline $\begin{array}{l}\text { Rawnsley Quartzite } \\
\text { (Npr) }\end{array}$ & Flinders Ranges & 872 & $562 \pm 15$ & $562 \pm 15$ & $570 \pm 23$ & $603 \pm 115$ & $\begin{array}{l}583 \pm 8 \\
(5 ; 0.68)\end{array}$ & & $570 \pm 23$ & $\begin{array}{l}\text { LA-ICP-MS } \\
\text { Detrital Zircon }\end{array}$ & $\begin{array}{l}\text { This study; Keeman et } \\
\text { al. (2020) }\end{array}$ \\
\hline $\begin{array}{l}\text { Bonney Sandstone } \\
(\mathrm{Npb})\end{array}$ & Flinders Ranges & 751 & $568 \pm 18$ & $568 \pm 18$ & $579 \pm 32$ & $623 \pm 155$ & $\begin{array}{l}587 \pm 10 \\
(3 ; 0.75)\end{array}$ & & $579 \pm 32$ & $\begin{array}{l}\text { LA-ICP-MS } \\
\text { Detrital Zircon }\end{array}$ & $\begin{array}{l}\text { Ireland et al. (1998); } \\
\text { this study }\end{array}$ \\
\hline Yarloo Shale (Nwy) & Stuart Shelf & & & & & & & $588 \pm 35$ & & Rb-Sr Whole Rock & Webb (1980) \\
\hline $\begin{array}{l}\text { Bunyeroo } \\
\text { Formation (Nwb) }\end{array}$ & $\begin{array}{l}\text { North Flinders } \\
\text { Ranges }\end{array}$ & 20 & $1041 \pm 26$ & & & $1041 \pm 154$ & & & $1041 \pm 26$ & $\begin{array}{l}\text { SHRIMP Detrital } \\
\text { Zircon }\end{array}$ & $\begin{array}{l}\text { Compston et al. } \\
\text { (1987) }\end{array}$ \\
\hline $\begin{array}{l}\text { ABC Range } \\
\text { Quartzite (Nsa) }\end{array}$ & $\begin{array}{l}\text { South Flinders } \\
\text { Ranges }\end{array}$ & 173 & $\begin{array}{l}622 \pm 24 \\
630 \pm 16\end{array}$ & $\begin{array}{l}622 \pm 24 \\
630 \pm 16\end{array}$ & $\begin{array}{l}630 \pm 44 \\
629 \pm 28\end{array}$ & $\begin{array}{l}662 \pm 208 \\
626 \pm 140\end{array}$ & $\begin{array}{l}645 \pm 6 \\
(8,0.77)\end{array}$ & & $630 \pm 16$ & $\begin{array}{l}\text { LA-ICP-MS } \\
\text { Detrital Zircon }\end{array}$ & $\begin{array}{l}\text { This study; Keeman et } \\
\text { al. (2020) }\end{array}$ \\
\hline $\begin{array}{l}\text { Brachina Formation } \\
(\mathrm{Nsb})\end{array}$ & & & & & & & & $609 \pm 64$ & & $\begin{array}{l}\text { LA-ICP-MS } \\
\text { Detrital Zircon }\end{array}$ & $\begin{array}{l}\text { Compston et al. } \\
\text { (1987) }\end{array}$ \\
\hline $\begin{array}{l}\text { Whyalla Sandstone } \\
\text { (Neh) }\end{array}$ & Stuart Shelf & 561 & $641 \pm 6$ & $617 \pm 11$ & $624 \pm 17$ & $641 \pm 6$ & & & $641 \pm 6$ & $\begin{array}{l}\text { LA-ICP-MS } \\
\text { Detrital Zircon }\end{array}$ & Rose et al. (2013) \\
\hline $\begin{array}{l}\text { Elatina Formation } \\
\text { (Nee) }\end{array}$ & $\begin{array}{l}\text { Flinders Ranges } \\
\text { South Mount Lofty } \\
\text { Ranges }\end{array}$ & 896 & $652 \pm 13$ & $652 \pm 13$ & $656 \pm 15$ & $671 \pm 52$ & $\begin{array}{l}662 \pm 5 \\
(8 ; 0.12)\end{array}$ & & $671 \pm 52$ & $\begin{array}{l}\text { LA-ICP-MS } \\
\text { Detrital Zircon }\end{array}$ & $\begin{array}{l}\text { Gehrels et al. (1996); } \\
\text { Rose et al. (2013); } \\
\text { this study }\end{array}$ \\
\hline $\begin{array}{l}\text { Yaltipena } \\
\text { Formation (Nil) }\end{array}$ & $\begin{array}{l}\text { South Flinders } \\
\text { Ranges }\end{array}$ & 71 & $652 \pm 13$ & $662 \pm 20$ & $659 \pm 30$ & $652 \pm 13$ & $\begin{array}{l}662 \pm 8 \\
(3 ; 0.71)\end{array}$ & & $662 \pm 20$ & $\begin{array}{l}\text { LA-ICP-MS } \\
\text { Detrital Zircon }\end{array}$ & Rose et al. (2013) \\
\hline $\begin{array}{l}\text { Trezona Formation } \\
\text { (Niz) }\end{array}$ & $\begin{array}{l}\text { North Flinders } \\
\text { Ranges }\end{array}$ & 119 & $674 \pm 11$ & $674 \pm 11$ & $670 \pm 25$ & $650 \pm 16$ & & & $674 \pm 11$ & $\begin{array}{l}\text { LA-ICP-MS } \\
\text { Detrital Zircon }\end{array}$ & Rose et al. (2013) \\
\hline $\begin{array}{l}\text { Wilmington } \\
\text { Formation (Niw) }\end{array}$ & $\begin{array}{l}\text { South Mount Lofty } \\
\text { Ranges }\end{array}$ & 94 & $655 \pm 34$ & $655 \pm 34$ & & $666 \pm 614$ & $\begin{array}{l}688 \pm 8 \\
(4 ; 0.99)\end{array}$ & & $688 \pm 8$ & $\begin{array}{l}\text { LA-ICP-MS } \\
\text { Detrital Zircon }\end{array}$ & $\begin{array}{l}\text { Ireland et al. (1998); } \\
\text { this study }\end{array}$ \\
\hline $\begin{array}{l}\text { Enorama Shale } \\
\text { (Nie) }\end{array}$ & $\begin{array}{l}\text { North Flinders } \\
\text { Ranges }\end{array}$ & & & & & & & $680 \pm 23$ & & $\begin{array}{l}\text { Electron } \\
\text { Microprobe } \\
\text { Authigenic } \\
\text { Monazite }\end{array}$ & Mahan et al. (2010) \\
\hline $\begin{array}{l}\text { Amberoona } \\
\text { Formation (Nib) }\end{array}$ & $\begin{array}{l}\text { North Flinders } \\
\text { Ranges (Willouran } \\
\text { Ranges) }\end{array}$ & 14 & $1090 \pm 36$ & $1090 \pm 36$ & & $1110 \pm 71$ & & & $1110 \pm 71$ & $\begin{array}{l}\text { LA-ICP-MS } \\
\text { Detrital Zircon }\end{array}$ & This study \\
\hline
\end{tabular}


This accepted manuscript is a post-print version made available as per Elsevier's sharing policy under a CC-BY-NC-ND license. The final peer reviewed publication in Precambrian Research can be found at https://doi.org/10.1016/i.precamres.2020.105849

Table 2 - Summary of Adelaide Superbasin (Neoproterozoic) Geochronology with Maximum Depositional Ages (MDA)

\begin{tabular}{|c|c|c|c|c|c|c|c|c|c|c|c|}
\hline Formation & Region & $\begin{array}{l}\text { n zircon } \\
\text { (filtered) }\end{array}$ & $\begin{array}{l}\text { Auto MDA } \\
\text { (Ma) } \mathrm{YSG}^{\wedge}\end{array}$ & $\begin{array}{l}{ }^{206} \mathrm{~Pb} /{ }^{238} \mathrm{U} \\
\text { Age of YSG } \\
(\mathrm{Ma})\end{array}$ & $\begin{array}{l}{ }^{207} \mathrm{~Pb} /{ }^{235} \mathrm{U} \\
\text { Age of } \\
\text { YSG (Ma) }\end{array}$ & $\begin{array}{l}{ }^{207} \mathrm{~Pb} /{ }^{206} \mathrm{~Pb} \\
\text { Age of YSG } \\
\text { (Ma) }\end{array}$ & $\begin{array}{l}\text { MDA (Ma) } \\
\text { YPA* } \\
\text { (n; MSWD) }\end{array}$ & $\begin{array}{l}\text { Depositional } \\
\text { Age (Ma) (Syn } \\
\text {, Min.) }\end{array}$ & $\begin{array}{l}\text { Preferred } \\
\text {-MDA }{ }^{\&}(\mathrm{Ma})\end{array}$ & $\begin{array}{l}\text { Geochronology } \\
\text { Method }\end{array}$ & $\begin{array}{l}\text { Original Data } \\
\text { Source }\end{array}$ \\
\hline Tapley Hill & North Flinders & 75 & $654 \pm 13$ & $654 \pm 13$ & & $640 \pm 87$ & & & $654 \pm 13$ & LA-ICP-MS & Shahin (2016) \\
\hline Formation (Nnt) & Ranges & & & & & & & & & Detrital Zircon & \\
\hline Tindelpina Shale & North Flinders & & & & & & & $643 \pm 2.4$ & & Re-Os Whole Rock & k Kendall et al. (2006) \\
\hline Member (Nntt) & Ranges & & & & & & & & & & \\
\hline $\begin{array}{l}\text { Tuff in Wilyerpa } \\
\text { (Nyw) }\end{array}$ & $\begin{array}{l}\text { North Flinders } \\
\text { Ranges }\end{array}$ & & & & & & & $663 \pm 0.11$ & & $\begin{array}{l}\text { CA-ID-TIMS } \\
\text { Igneous Zircon }\end{array}$ & Cox et al. (2018) \\
\hline Appila Tillite (Nya) & $\begin{array}{l}\text { South Flinders } \\
\text { Ranges }\end{array}$ & 108 & $638 \pm 30$ & $638 \pm 30$ & $640 \pm 64$ & $647 \pm 147$ & $\begin{array}{l}667 \pm 6 \\
(7 ; 0.45)\end{array}$ & & $667 \pm 6$ & $\begin{array}{l}\text { LA-ICP-MS } \\
\text { Detrital Zircon }\end{array}$ & Keeman et al. (2020) \\
\hline $\begin{array}{l}\text { Bolla Bollana Tillite } \\
(\mathrm{Nyb})\end{array}$ & $\begin{array}{l}\text { North Flinders } \\
\text { Ranges (Willouran } \\
\text { Ranges) }\end{array}$ & 218 & $673 \pm 19$ & $673 \pm 19$ & & $667 \pm 160$ & & & $673 \pm 19$ & $\begin{array}{l}\text { LA-ICP-MS } \\
\text { Detrital Zircon }\end{array}$ & Shahin (2016) \\
\hline $\begin{array}{l}\text { Gilbert Range } \\
\text { Quartzite (Nlg) }\end{array}$ & $\begin{array}{l}\text { North Mount Lofty } \\
\text { Ranges }\end{array}$ & 57 & $694 \pm 6$ & $694 \pm 6$ & $703 \pm 16$ & $731 \pm 34$ & & & $731 \pm 34$ & $\begin{array}{l}\text { LA-ICP-MS } \\
\text { Detrital Zircon }\end{array}$ & Keeman et al. (2020) \\
\hline $\begin{array}{l}\text { Mitcham Quartzite } \\
(\mathrm{N} l \mathrm{~m})\end{array}$ & $\begin{array}{l}\text { South Mount Lofty } \\
\text { Ranges }\end{array}$ & 35 & $1053 \pm 42$ & $1053 \pm 42$ & & $1033 \pm 60$ & & & $1053 \pm 42$ & $\begin{array}{l}\text { LA-ICP-MS } \\
\text { Detrital Zircon }\end{array}$ & Ireland et al. (1998) \\
\hline $\begin{array}{l}\text { Skillogalee } \\
\text { Dolomite } \\
(\mathrm{Nms})(\mathrm{Nmsk})\end{array}$ & \begin{tabular}{|l} 
North Flinders \\
Ranges \\
North Mount Lofty \\
Ranges
\end{tabular} & 632 & $782 \pm 24$ & $782 \pm 24$ & & $777 \pm 36$ & $\begin{array}{l}789 \pm 9 \\
(7 ; 0.05)\end{array}$ & ca. 790 & $789 \pm 9$ & $\begin{array}{l}\text { LA-ICP-MS } \\
\text { Detrital Zircon } \\
\text { LA-ICP-MS } \\
\text { Volcaniclastic } \\
\text { Zircon }\end{array}$ & $\begin{array}{l}\text { Drabsch (2016); } \\
\text { Fabris et al. (2005); } \\
\text { Mackay (2011); this } \\
\text { study }\end{array}$ \\
\hline $\begin{array}{l}\text { Copley Quartzite } \\
\text { (Noc) }\end{array}$ & $\begin{array}{l}\text { North Flinders } \\
\text { Ranges }\end{array}$ & 188 & $1129 \pm 51$ & $1129 \pm 51$ & & $1110 \pm 190$ & & & $1129 \pm 51$ & $\begin{array}{l}\text { LA-ICP-MS } \\
\text { Detrital Zircon }\end{array}$ & Drabsch (2016) \\
\hline $\begin{array}{l}\text { Blue Mine } \\
\text { Conglomerate } \\
\text { (Nou) }\end{array}$ & $\begin{array}{l}\text { North Flinders } \\
\text { Ranges }\end{array}$ & 76 & $1106 \pm 85$ & $1106 \pm 85$ & $1099 \pm 30$ & $1083 \pm 85$ & & & $1106 \pm 85$ & $\begin{array}{l}\text { LA-ICP-MS } \\
\text { Detrital Zircon }\end{array}$ & Job (2011) \\
\hline $\begin{array}{l}\text { Rhynie Sandstone } \\
\text { (Nor) }\end{array}$ & $\begin{array}{l}\text { North Mount Lofty } \\
\text { Ranges }\end{array}$ & 27 & $1512 \pm 10$ & $1513 \pm 26$ & $1513 \pm 26$ & $1512 \pm 10$ & $\begin{array}{l}1518 \pm 5 \\
(3 ; 0.24)\end{array}$ & & $1513 \pm 26$ & $\begin{array}{l}\text { LA-ICP-MS } \\
\text { Detrital Zircon }\end{array}$ & Gehrels et al. (1996) \\
\hline $\begin{array}{l}\text { Humanity Seat } \\
\text { Formation (Noh) }\end{array}$ & $\begin{array}{l}\text { North Flinders } \\
\text { Ranges }\end{array}$ & 130 & $1022 \pm 17$ & $1022 \pm 17$ & $1033 \pm 40$ & $1053 \pm 114$ & & & $1053 \pm 114$ & $\begin{array}{l}\text { LA-ICP-MS } \\
\text { Detrital Zircon }\end{array}$ & $\begin{array}{l}\text { Job (2011); Mackay } \\
\text { (2011) }\end{array}$ \\
\hline $\begin{array}{l}\text { Top Mount } \\
\text { Sandstone (Not) }\end{array}$ & $\begin{array}{l}\text { North Flinders } \\
\text { Ranges (Willouran } \\
\text { Ranges) }\end{array}$ & 85 & $841 \pm 21$ & $841 \pm 21$ & $840 \pm 34$ & $790 \pm 130$ & & & $841 \pm 21$ & $\begin{array}{l}\text { LA-ICP-MS } \\
\text { Detrital Zircon }\end{array}$ & This study \\
\hline
\end{tabular}


This accepted manuscript is a post-print version made available as per Elsevier's sharing policy under a CC-BY-NC-ND license. The final peer reviewed publication in Precambrian Research can be found at https://doi.org/10.1016/i.precamres.2020.105849

Table 2 - Summary of Adelaide Superbasin (Neoproterozoic) Geochronology with Maximum Depositional Ages (MDA)

\begin{tabular}{|c|c|c|c|c|c|c|c|c|c|c|c|}
\hline Formation & Region & $\begin{array}{l}\text { n zircon } \\
\text { (filtered) }\end{array}$ & $\begin{array}{l}\text { Auto MDA } \\
\text { (Ma) } \mathrm{YSG}^{\wedge}\end{array}$ & $\begin{array}{l}{ }^{206} \mathrm{~Pb} /{ }^{238} \mathrm{U} \\
\text { Age of YSG } \\
\text { (Ma) }\end{array}$ & $\begin{array}{l}{ }^{207} \mathrm{~Pb} /{ }^{235} \mathrm{U} \\
\text { Age of } \\
\text { YSG (Ma) }\end{array}$ & $\begin{array}{l}{ }^{207} \mathrm{~Pb} /{ }^{206} \mathrm{~Pb} \\
\text { Age of YSG } \\
\text { (Ma) }\end{array}$ & $\begin{array}{l}\text { MDA (Ma) } \\
\text { YPA* } \\
\text { (n; MSWD) }\end{array}$ & $\begin{array}{l}\text { Depositional } \\
\text { Age (Ma) (Syn } \\
\text {, Min.) }\end{array}$ & $\begin{array}{c}\text { Preferred } \\
\text { n-MDA }(M a)\end{array}$ & $\begin{array}{l}\text { Geochronology } \\
\text { Method }\end{array}$ & $\begin{array}{l}\text { Original Data } \\
\text { Source }\end{array}$ \\
\hline $\begin{array}{l}\text { Emeroo Subgroup } \\
\text { (undifferentiated) } \\
\text { (No) }\end{array}$ & $\begin{array}{l}\text { North Flinders } \\
\text { Ranges (Willouran } \\
\text { Ranges) }\end{array}$ & 22 & No data is wi & ithin $2 \%$ of cor & ncordance & & & & & $\begin{array}{l}\text { LA-ICP-MS } \\
\text { Detrital Zircon }\end{array}$ & Mackay (2011) \\
\hline $\begin{array}{l}\text { Boucaut Volcanics } \\
\text { (Nox) }\end{array}$ & Nackara Arc & & & & & & & ca. 788 & & $\begin{array}{l}\text { LA-ICP-MS } \\
\text { Igneous Zircon }\end{array}$ & $\begin{array}{l}\text { Armistead et al. in } \\
\text { prep, pers. comm. }\end{array}$ \\
\hline $\begin{array}{l}\text { Mount Crawford } \\
\text { Granite Gneiss ( } N \text { - } \\
\text { f) }\end{array}$ & $\begin{array}{l}\text { South Mount Lofty } \\
\text { Ranges }\end{array}$ & & & & & & & $\begin{array}{l}812 \pm 6 \mathrm{Ma} \\
856 \pm 20 \mathrm{Ma}\end{array}$ & & $\begin{array}{l}\text { SHRIMP Igneous } \\
\text { Zircon }\end{array}$ & Preiss et al. (2008) \\
\hline $\begin{array}{l}\text { Recovery } \\
\text { Formation }(N k r)\end{array}$ & $\begin{array}{l}\text { North Flinders } \\
\text { Ranges (Willouran } \\
\text { Ranges) }\end{array}$ & 2 & No data is wi & ithin $2 \%$ of cor & ncordance & & & & & $\begin{array}{l}\text { LA-ICP-MS } \\
\text { Detrital Zircon }\end{array}$ & Mackay (2011) \\
\hline $\begin{array}{l}\text { Niggly Gap Beds } \\
(N k n)\end{array}$ & $\begin{array}{l}\text { North Mount Lofty } \\
\text { Ranges }\end{array}$ & 30 & $1583 \pm 48$ & $1583 \pm 48$ & & $1616 \pm 34$ & $\begin{array}{l}1599 \pm 10 \\
(8,0.11)\end{array}$ & & $1616 \pm 34$ & $\begin{array}{l}\text { LA-ICP-MS } \\
\text { Detrital Zircon }\end{array}$ & Ireland et al. (1998) \\
\hline $\begin{array}{l}\text { Oodla Wirra } \\
\text { Volcanics (Nkx) }\end{array}$ & Nackara Arc & & & & & & & $\begin{array}{l}798 \pm 5 \\
799 \pm 4\end{array}$ & & $\begin{array}{l}\text { SHRIMP Igneous } \\
\text { Zircon }\end{array}$ & Fabris et al. (2005) \\
\hline Rook Tuff (Nkk) & $\begin{array}{l}\text { North Flinders } \\
\text { Ranges (Willouran } \\
\text { Ranges) }\end{array}$ & & & & & & & $802 \pm 10$ & & $\begin{array}{l}\text { SHRIMP Igneous } \\
\text { Zircon }\end{array}$ & Fanning et al. (1986) \\
\hline $\begin{array}{l}\text { Dome Sandstone } \\
(N k d)\end{array}$ & $\begin{array}{l}\text { North Flinders } \\
\text { Ranges (Willouran } \\
\text { Ranges) }\end{array}$ & 147 & $993 \pm 62$ & $993 \pm 62$ & $988 \pm 102$ & $771 \pm 330$ & & & $993 \pm 62$ & $\begin{array}{l}\text { LA-ICP-MS } \\
\text { Detrital Zircon }\end{array}$ & Mackay (2011) \\
\hline $\begin{array}{l}\text { Wooltana Volcanics } \\
\text { (Nal) }\end{array}$ & $\begin{array}{l}\text { sorth Flinders } \\
\text { Ranges }\end{array}$ & & & & & & & $830 \pm 50$ & & Rb-Sr Whole Rock & k Preiss (2000) \\
\hline $\begin{array}{l}\text { Paralana Quartzite } \\
\text { (Nap) }\end{array}$ & $\begin{array}{l}\text { North Flinders } \\
\text { Ranges }\end{array}$ & 66 & $\begin{array}{l}1164 \pm 52 \\
1169 \pm 22\end{array}$ & $\begin{array}{l}1164 \pm 52 \\
1177 \pm 28\end{array}$ & $\begin{array}{l}1279 \pm 158 \\
1169 \pm 22\end{array}$ & $\begin{array}{l}81266 \pm 146 \\
1154 \pm 55\end{array}$ & $\begin{array}{l}1171 \pm 16 \\
(3,0.03)\end{array}$ & & $1177 \pm 28$ & $\begin{array}{l}\text { LA-ICP-MS } \\
\text { Detrital Zircon }\end{array}$ & $\begin{array}{l}\text { Job (2011); Mackay } \\
\text { (2011) }\end{array}$ \\
\hline
\end{tabular}


This accepted manuscript is a post-print version made available as per Elsevier's sharing policy under a CC-BY-NC-ND license. The final peer reviewed publication in Precambrian Research can be found at

https://doi.org/10.1016/i.precamres.2020.105849

871

872

873

874

875

876

877

878

879

880

881

882

883

884

885

886

887

888

889

890

891

892

893

894

895

896

\subsection{Provenance}

Previous studies that dealt with detrital zircon provenance of the sedimentary rocks in the Adelaide Superbasin (Gehrels et al. 1996; Haines et al. 2004; Ireland et al. 1998; Keeman et al. 2020; Rose et al. 2013) noted that many of the zircons yielded Mesoproterozoic ages that were broadly consistent with being sourced from the Musgrave Orogen of central Australia. Previous studies have also reached a consensus that the early Mesoproterozoic and older zircon populations found in the preSturtian formations are derived from the Gawler Craton and Curnamona Province [Figure 5, Figure 11]. It was also apparent that few zircons came from sources close to the age of deposition as would be expected from a non-volcanic region (Cawood et al. 2012). In addition, it was noted that time equivalent formations, such as the Whyalla Sandstone and Elatina Formation, preserved different age spectra, indicative of differing detrital source, and significant provinciality in sediment supply-at least at specific times (Rose et al. 2013). Limited Samarium-Neodymium (Sm-Nd), and Strontium (Sr) isotopic studies (Barovich \& Foden 2000; Haines et al. 2009; Turner et al. 1993b) of samples within the Adelaide Superbasin and basement rocks (Gawler Craton, Curnamona Province) have noted that a heterogeneity of detritus sources is required to explain the observed Sm-Nd signatures of the formations within the Adelaide Superbasin. Turner et al. (1993b), also noted that the Sturtian glaciogenic formations yielded $\varepsilon N d$ and $T_{D M}$ values more similar to that of the Callanna Group and suggested this represented a transitory restriction of source region to the local basementpotentially representing the development of uplifted rift shoulders at this time. The heterogeneity of detritus sources for the Adelaide Superbasin contrasts the findings for the coeval Amadeus Basin where Barovich and Foden (2000) note a mature and homogeneous source region for clay-mica fractions of the rocks. Although not the focus of this study, the Kanmantoo Group (Kanmantoo Province, Figure 3) of the Moralana Supergroup has been suggested to access more locally derived ancient basement detritus (Gawler Craton, Figure 5), with an influx of late Neoproterozoic-early Cambrian aged zircons (Haines et al. 2009; Keeman et al. 2020; Turner et al. 1993a). Our results broadly agree with previous studies but provide a finer level of detail for the Neoproterozoic, 
This accepted manuscript is a post-print version made available as per Elsevier's sharing policy under a CC-BY-NC-ND license. The final peer reviewed publication in Precambrian Research can be found at https://doi.org/10.1016/i.precamres.2020.105849

897

898

899

900

901

902

903

904

905

906

907

908

909

910

911

912

913

914

915

916

917

verifying the findings of most previous studies. Our latest Ediacaran samples from the Bonney

Sandstone, Rawnsley Quartzite and Billy Springs Formation provide conflicting findings to those of (Keeman et al. 2020) where we observe a shift toward younger late Mesoproterozoic zircon populations away from $1180 \mathrm{Ma}$ [Figure 8, Figure 9] rather than an shift toward an older $1180 \mathrm{Ma}$ peak. With the corresponding increase in ca. $600 \mathrm{Ma}$ and younger zircon populations [Figure 8, Figure 9] we suggest that this as the influx of a younger, southerly-derived, detritus.

Compiling all legacy data and adding new detrital data allows us to analyse the most comprehensive dataset to date and identify the general trends of provenance variation within a chronostratigraphic framework. The most significant trends are identified are below.

- Younger populations become significantly more prevalent as the formations young [Figure 9]. This is opposite to what might be expected if a layered sequence was progressively unroofed during deposition.

- Early Mesoproterozoic populations are less abundant in younger formations [Figure 8, Figure 9]. This is coupled with a rise in dominance of late Mesoproterozoic zircons.

- There is a subtle, but notable, shift in late Mesoproterozoic zircons to younger ages away from ca. 1180 Ma [Figure 8, Figure 9].

- Coeval Sturtian glacial formations show differing age spectra [Figure 8, Figure 9, Figure 10] that we relate to heterogenous sources.

- Rare Eoarchaean to Palaeoarchaean zircons are more abundant in the youngest formations but coincide with more prevalent Neoproterozoic and late Mesoproterozoic populations [Figure 9]. 
This accepted manuscript is a post-print version made available as per Elsevier's sharing policy under a CC-BY-NC-ND license. The final peer reviewed publication in Precambrian Research can be found at https://doi.org/10.1016/i.precamres.2020.105849

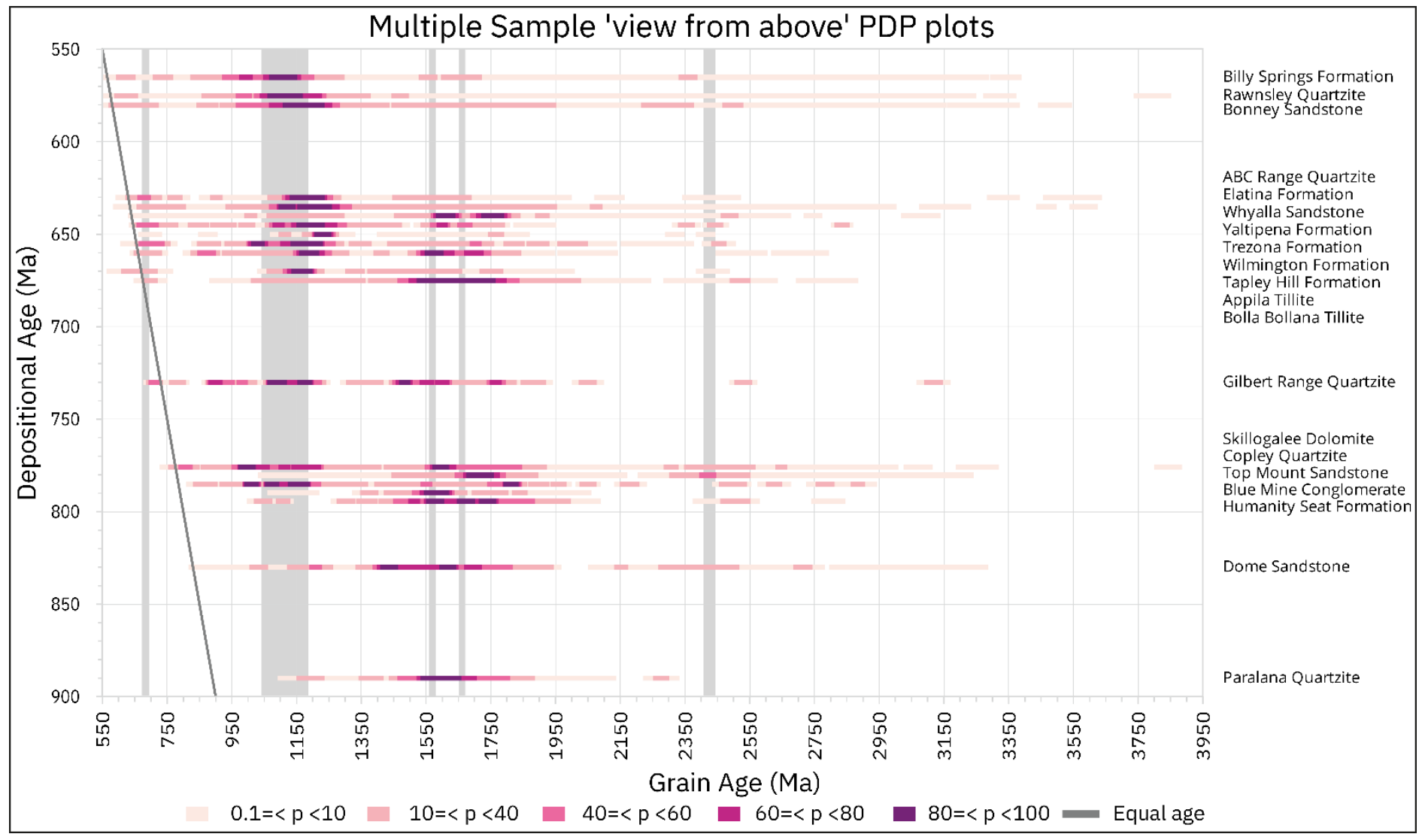

Figure 9 - Multiple sample, 'view from above' probability density plots (PDP) of formations ( $n>40)$ in this study, highlighting the change in relative dominance of Proterozoic populations. Each variably coloured 'bar' represents a PDP of one formation; however, it is viewed from a top-down perspective. The darker colours represent higher probabilities, or peaks, of a traditional PDP. The general trend shows a decrease in probability of late Mesoproterozoic ages and a corresponding increase in Neoproterozoic ages with decreasing depositional age. It can also be seen that the late Mesoproterozoic ages show a shift in age from ca. $1700 \mathrm{Ma}$ to ca. $1100 \mathrm{Ma}$, likely related to a change in provenance. The grey vertical bars highlight the centralised population peaks as established by the KDE graphs [Figure 8]; they correspond to the synthetic peaks used in the MDS plot [Figure 10]. Depositional ages are a "best guess" estimate based on the previously described age constraints and the established stratigraphic relationships. It is more important to assign depositional ages that represent the stratigraphic relationships of the formations, rather than precise true depositional ages. The order of 
This accepted manuscript is a post-print version made available as per Elsevier's sharing policy under a CC-BY-NC-ND license. The final peer reviewed publication in Precambrian Research can be found at https://doi.org/10.1016/i.precamres.2020.105849

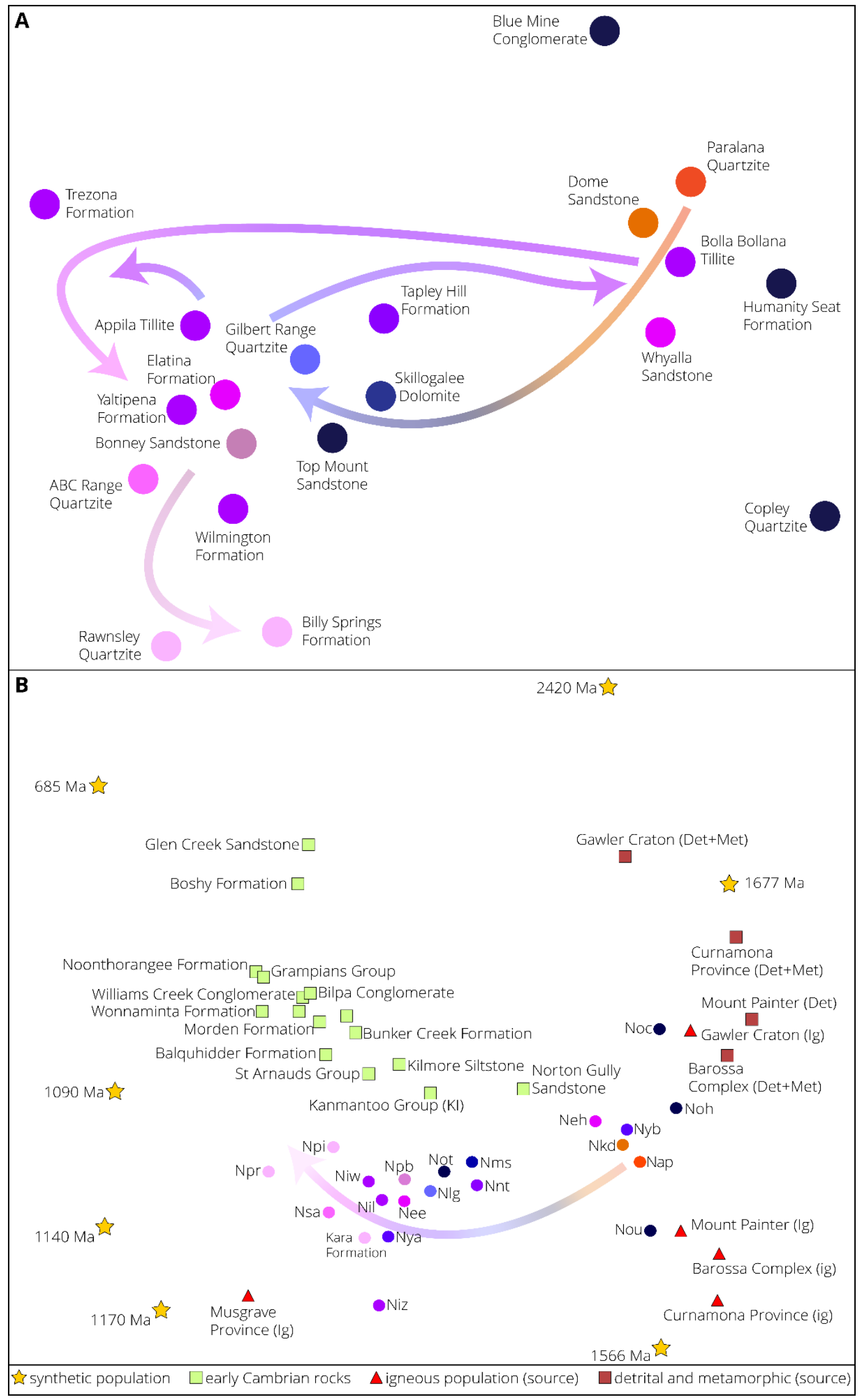


This accepted manuscript is a post-print version made available as per Elsevier's sharing policy under a CC-BY-NC-ND license. The final peer reviewed publication in Precambrian Research can be found at https://doi.org/10.1016/j.precamres.2020.105849

930 Figure 10 - Non-metric multidimensional scaling plots of detrital zircon ( $\mathrm{n}>40)$ data within the Adelaide Superbasin ( $A$ ) and with synthetic peaks, some probable provenance sources and some examples from early Cambrian rocks of the Delamerian and Lachlan Orogenic belts.(B). These plots show the relative similarities of all data to each other and are intended as a visual guide. In (A) stratigraphic groups are represented by colour where orange = Callanna Group (oldest), blue = Burra Group, purple = Umberatana Group, and pink = Wilpena Group (youngest). The lightness of these colours represents time where darker shades are older formations and lighter shades are younger formations. The coloured arrows in (a) show the nuanced changes and point in the direction of stratigraphic up, i.e. arrowhead points younger, whilst the coloured arrow in (b) shows the overall trend in provenance change. Plotted using IsoplotR (Vermeesch 2018b). Axes are omitted as the algorithm used produces normalised values with no physical meaning and can be safely removed.

\subsubsection{Reliability of dataset for provenance interpretations}

940 Although a reasonable number of individual detrital ages exist for Adelaide Superbasin samples, data are 941 concentrated within a few specific formations. Approximately $70 \%$ of the entire detrital dataset comes from 942 just six of the 143 formation ranked units (117 named; 26 unnamed) within the Neoproterozoic of the 943 Adelaide Superbasin. These are the Skillogalee Dolomite ( 10.9\%), the Elatina Formation ( $15.5 \%)$, the 944 Whyalla Sandstone ( 9.7\%), the Bonney Sandstone ( 13\%), the Rawnsley Quartzite ( 15.1\%), and the Billy 945 Springs Formation ( $5.5 \%)$. This limits this ability to accurately assess changes in provenance through time 946 for the Adelaide Superbasin. More importantly, only 14 of the 26 formations with data have the statistically 947 optimal 117 concordant analyses (Vermeesch 2004) in which it can be confidently stated that no fraction of 948 the true population that equates to $\geq 5 \%$ of the population is missed. Further, 13 formations have less than 949 the recommended minimum of 95 concordant analyses in which it can be stated that no fraction of the true 950 population that equates to $\geq 5 \%$ of the population is missed. As the number of grains $(n)$ decreases, the 951 dissimilarity to the true population increases and they become further statistically unreliable. As such, it is 952 likely where $n$ (grains) $\leq 95$ that the observed populations are likely missing representative components of 953 the true population and require further data. In addition, most of the data comes from the North Flinders 954 Ranges ( $63.5 \%$ ), with only $\sim 4.5 \%$ of the data coming from the Mount Lofty Ranges covering four 955 formations, and no data from the Olary region [Figure 1, Figure 4]. This lack of spatial diversity in the dataset 956 limits the assessment of spatial variation on provenance, a concept important in such a large basin that 957 covers over $800 \mathrm{~km}$ north-south and $\sim 400 \mathrm{~km}$ east-west.

\section{5.2.2. Archaean}

959 Archaean zircon make up only a small percentage of the dataset with no sizeable population peaks showing 960 on Figure 9. The oldest eleven grains range between ca. 3825 and 3297 Ma. Except for one grain in the 
This accepted manuscript is a post-print version made available as per Elsevier's sharing policy under a CC-BY-NC-ND license. The final peer reviewed publication in Precambrian Research can be found at https://doi.org/10.1016/i.precamres.2020.105849

961 Skillogalee Dolomite, these Eo- to Palaeoarchaean grains are found in the Elatina Formation of the Marinoan 962 glaciation, or in younger formations.

963 Locally, the Gawler Craton records magmatic events at ca. 3250 Ma, 3150 Ma, 2820 Ma, and 2560-2470

$964 \mathrm{Ma}$, and inherited/detrital zircon up to 3400 Ma (Fanning et al. 2007; Fraser et al. 2010; Fraser \& Neumann

965 2010; Jagodzinski \& McAvaney 2017; McAvaney 2012; Reid \& Jagodzinski 2011). Zircons of these ages may

966 also be derived by recycling from the Willyama Supergroup in the Curnamona Province that contains detrital

967 populations ca. 3000-2980 Ma, and ca. 2680-2650 Ma (Page et al. 2005). These may originally be sourced

968 from the North Australian Craton (Barovich \& Hand 2008). It is likely that zircon between ca. 3400 and ca.

9693290 Ma represent recycling of inherited zircon from the Gawler Craton. This still leaves six grains above ca.

$9703400 \mathrm{Ma}$, with two being ca. $3800 \mathrm{Ma}$, which have no known local source.

971 The two ca. 3800 Ma grains are near concordant and have limited regions from which they can be sourced.

972 Possible location that are relatively close $(<5000 \mathrm{~km})$ in contemporaneous reconstructions include recycling 973 detrital zircon (up to ca. $4400 \mathrm{Ma}$ ) of the Narryer and Youanmi Terranes of the Yilgarn Craton, Western 974 Australia (Wilde \& Spaggiari 2007; Wyche 2007), the Anshan Region of the North China Craton, ca. 3811 to 9753800 Ma, (Liu et al. 2007), and the Mount Sones and Gage Ridge area of the Napier Complex, Antarctica, ca. 9763927 and $3850 \mathrm{Ma}$, (Black et al. 1986; Blewett et al. 2012; Harley \& Kelly 2007) The concentration of 977 zircons of this antiquity in the Ediacaran rocks may suggest a southern, Antarctic source, in keeping with the 978 discussion below.

\section{5.2.3. Palaeoproterozoic}

980 The first population peak that is consistently recorded through the formations of the Adelaide Superbasin 981 occurs at ca. 2480-2420 Ma [Figure 9]. This correlates well with the Sleaford Orogeny of the Gawler Craton 982 (Reid et al. 2014). The most significant peak in the detrital spectra within the Palaeoproterozoic occurs ca. $9831700 \mathrm{Ma}$. This age maximum is part of a continuum from ca. $2000 \mathrm{Ma}$ to the Mesoproterozoic. These 984 Palaeoproterozoic grains are likely sourced from the surrounding Gawler Craton [Figure 5], which records 985 numerous Palaeoproterozoic magmatic and metamorphic events (Belousova et al. 2009; Fanning et al. 986 2007; Fraser \& Neumann 2010; Jagodzinski \& Fricke 2010; Jagodzinski \& McAvaney 2017; McAvaney 2012; 
This accepted manuscript is a post-print version made available as per Elsevier's sharing policy under a CC-BY-NC-ND license. The final peer reviewed publication in Precambrian Research can be found at https://doi.org/10.1016/i.precamres.2020.105849

Meaney 2012; 2017; Morrissey et al. 2019; Reid \& Hand 2012; Reid \& Jagodzinski 2011; Reid \& Payne 2017; Swain et al. 2005), and recycling from the Curnamona Province, where likely Arunta Orogen [Figure 5] derived detritus (ca. 1790-1770 Ma) is found in the sedimentary sequences (Barovich \& Hand 2008). The Yavapai-Mazatzal Province of Laurentia [Figure 5] is a further possible source due to similarities in ages and proximity to the Adelaide Superbasin within some Rodinia reconstructions [Figure 2] (Brookfield 1993;

Dalziel 1991; Goodge et al. 2008; Hoffman 1991; Karlstrom \& Bowring 1988; Karlstrom et al. 1999; Moores 1991; Wingate et al. 2002). The predominance of Palaeoproterozoic detrital zircon reduces significantly up stratigraphy, becoming negligible in the Ediacaran sedimentary rocks of the Adelaide Superbasin [Figure 9], indicating a shift in predominant detritus source.

\subsubsection{Mesoproterozoic}

There is a major age peak ca. 1590-1550 Ma [Figure 9] that is present in Tonian formations of the Adelaide Superbasin that is not seen in the Ediacaran formations. The two most probable sources of these detrital zircon grains are the Ninnerie Supersuite and Radium Creek Group of the Curnamona Province (Armit et al. 2014; Wade, CE 2011), rocks of the Olarian Orogeny, the Isan Orogeny, and the Gawler Range Volcanics and Hiltaba Suite of the Gawler Craton (Fanning et al. 2007). The near absence of this peak within the Ediacaran formations of the Adelaide Superbasin [Figure 9] further suggests a change in predominant detrital sources up stratigraphy.

The second major peak in the Mesoproterozoic occurs ca. 1180-1050 Ma [Figure 9]. This late Mesoproterozoic peak becomes predominant in the latest Tonian, then declines in prevalence in early Cryogenian rocks, returning to significance in the middle Cryogenian and Ediacaran formations [Figure 9]. This return to prominence occurs between the two "Snowball Earth" events in the middle Cryogenian (Hoffman et al. 2017; Hoffman et al. 1998; Hoffman \& Li 2009), at the same time as the early Mesoproterozoic peak decreases in significance [Figure 9]. Interestingly, this late Mesoproterozoic peak shifts from ca. 1180-1150 Ma to ca. $1090 \mathrm{Ma}$ at about this time, with the peak younging correlating with the increased youth of the sequences [Figure 9]. These detrital zircons are likely sourced from the Pitjantjatjara and Warakurna Supersuites of the Musgrave Province [Figure 5] (Smithies et al. 2008; Smithies et al. 2011; 
This accepted manuscript is a post-print version made available as per Elsevier's sharing policy under a CC-BY-NC-ND license. The final peer reviewed publication in Precambrian Research can be found at https://doi.org/10.1016/j.precamres.2020.105849

1013 Smits et al. 2014; Wade, BP et al. 2008).

1014 Other potential sources of Mesoproterozoic zircon include the Albany-Fraser Orogeny of Western Australia

1015 (Spaggiari et al. 2015), which would require transport across the Gawler Craton [Figure 5]. Antarctic sources

1016 are also possible, which is where the late Mesoproterozoic/early Tonian zircon in the Palaeozoic Lachlan

1017 Orogen it thought to be derived (Squire et al. 2006). However, a distinguishing feature of these Lachlan

1018 Orogen zircons is the significant amount of <1050 Ma zircon, these are more characteristic of parts of East

1019 Antarctica such as the Tonian Oceanic Arc Super Terrane (TOAST, Jacobs et al. (2015)) and the Rayner

1020 Complex (Fitzsimons 2000).

$1021 \quad 5.2 .5 . \quad$ Neoproterozoic

1022 Neoproterozoic zircon populations are mostly absent in the older formations, which suggests limited to no 1023 sourcing of syndepositional magmatic zircons. This agrees with primarily mafic magmatism at the initial 1024 stages of the rift basin's development (Hillyard 1990; Preiss 1987). Cryogenian and younger formations 1025 commonly preserve limited Neoproterozoic detrital zircons, with a few samples containing moderate 1026 concentrations of 740-600 Ma detritus [Figure 8, Figure 9]. The first local sources of felsic magmatism occur 1027 at ca. $800 \mathrm{Ma}$ (Fanning et al. 1986) after which syndepositional age zircon begins to show in the age spectra.

1028 The sources of these late Tonian to early Ediacaran zircons (ca. 800-590 Ma) are difficult to determine as 1029 there are no known local sources for these late Tonian-early Ediacaran zircon. There is minor evidence for 1030 volcanism at ca. 790-780 Ma (Preiss et al. 2009), ca. $663 \mathrm{Ma}$ (Cox et al. 2018; Fanning \& Link 2006) and 1031 then ca. $580 \mathrm{Ma}$ (Black 2007), but little evidence for voluminous local sources of the observed detrital 1032 zircon. It has previously been posited that these detrital zircon may come from a source within Antarctica 1033 [Figure 5] (Veevers et al. 2006) or in part the East African Orogen (Squire et al. 2006). More recent models 1034 for formation of the East African Orogen preclude sources from this distance for pre-550 Ma formations as 1035 the Mozambique Ocean did not close until this time (Merdith et al. 2017a; Merdith et al. (submitted); Schmitt 1036 et al. 2018). More proximal Antarctic sources [Figure 5] from the Ross Orogen, or beneath the ice cover, 1037 cannot be discounted. 
This accepted manuscript is a post-print version made available as per Elsevier's sharing policy under a CC-BY-NC-ND license. The final peer reviewed publication in Precambrian Research can be found at https://doi.org/10.1016/i.precamres.2020.105849

1038

1039

1040

1041

1042

1043

1044

1045

1046

1047

1048

1049

1050

1051

1052

1053

1054

1055

1056

1057

1058

1059

1060

1061

1062

1063

\subsection{Tectonic and Palaeogeographic Evolution}

The Adelaide Superbasin formed via continental rifting with coincident fluvial, glacial, and marine sedimentation. It formed in a series of restricted basins that evolved into marine conditions as Laurentia moved away from Australia and the Pacific Ocean basin developed. The lithostratigraphic evolution of the basin is described in detail in Preiss (1987) and Preiss (2000); however, there are still unknowns, such as what was on the eastern margin of the Adelaide Superbasin [Figure 2]. Much of the detrital zircon research, a key component of tectonic reconstruction, postdates these publications. Here we integrate detrital zircon and other more recently published chronological constraints to set up a chronostratigraphic and sediment pathway framework for the Adelaide Superbasin.

Initial rifting appears to have developed over an extended period with detritus input initially supplied by local sources from the rift shoulders [Figure 8, Figure 9 \& Figure 10]. During the late Tonian there is a prominent shift toward younger, late Mesoproterozoic zircon detritus [Figure 9]. This new source is inferred to be from the Musgrave Province, with sediment distributed along the axis of the NW-SE Willouran rift [Figure 3], which fed sediment south into the Adelaide Superbasin. The Sturtian Glaciation punctuates this detrital progression with the earliest Cryogenian formations being dominated with early Mesoproterozoic zircon that is interpreted to reflect a return to erosion from local rift-shoulders and more distributed sediment sourcing [Figure 8, Figure 9].

The middle Cryogenian sees a return to predominantly younger Mesoproterozoic populations, with the addition of near depositional-age zircon populations and decreasing populations of early Mesoproterozoic zircon [Figure 9]. Stratigraphically, this change occurs at the Tapley Hill Formation [Figure 9, Figure 10], representing a transgression after the Sturtian glaciation (Preiss 2000). The subsequent Marinoan glacial deposits demonstrate the importance of looking at contemporaneous formations deposited in different regions to understand sediment distributary patterns. The Whyalla Sandstone is a broad time equivalent of the Elatina Formation, both being deposits from the Marinoan glaciation. Yet, the two formations show quite different zircon age spectra [Figure 8, Figure 9], indicating different source regions, or at least, different sediment distribution pathways [Figure 11]. Rose et al. (2013), suggested that the ca. 1700 Ma peak in the 
This accepted manuscript is a post-print version made available as per Elsevier's sharing policy under a CC-BY-NC-ND license. The final peer reviewed publication in Precambrian Research can be found at https://doi.org/10.1016/i.precamres.2020.105849

1064 Whyalla Sandstone spectra may have been ultimately derived from the Yavapai-Mazatzal Province of

1065 Laurentia but was recycled from the underlying Mesoproterozoic Pandurra Formation. The focus of

1066 Musgrave-derived detritus within the Elatina Formation; however, suggests that the detritus that filled up the

1067 ARC depocentres were focussed along a well-developed and deepened rift by this late Cryogenian time, with

1068 glacial and river systems flowing from the north-west through the Willouran Trough [Figure 3, Figure 11]

1069 (Counts 2016; Wade, BP et al. 2005). 
This accepted manuscript is a post-print version made available as per Elsevier's sharing policy under a CC-BY-NC-ND license. The final peer reviewed publication in Precambrian Research can be found at https://doi.org/10.1016/i.precamres.2020.105849

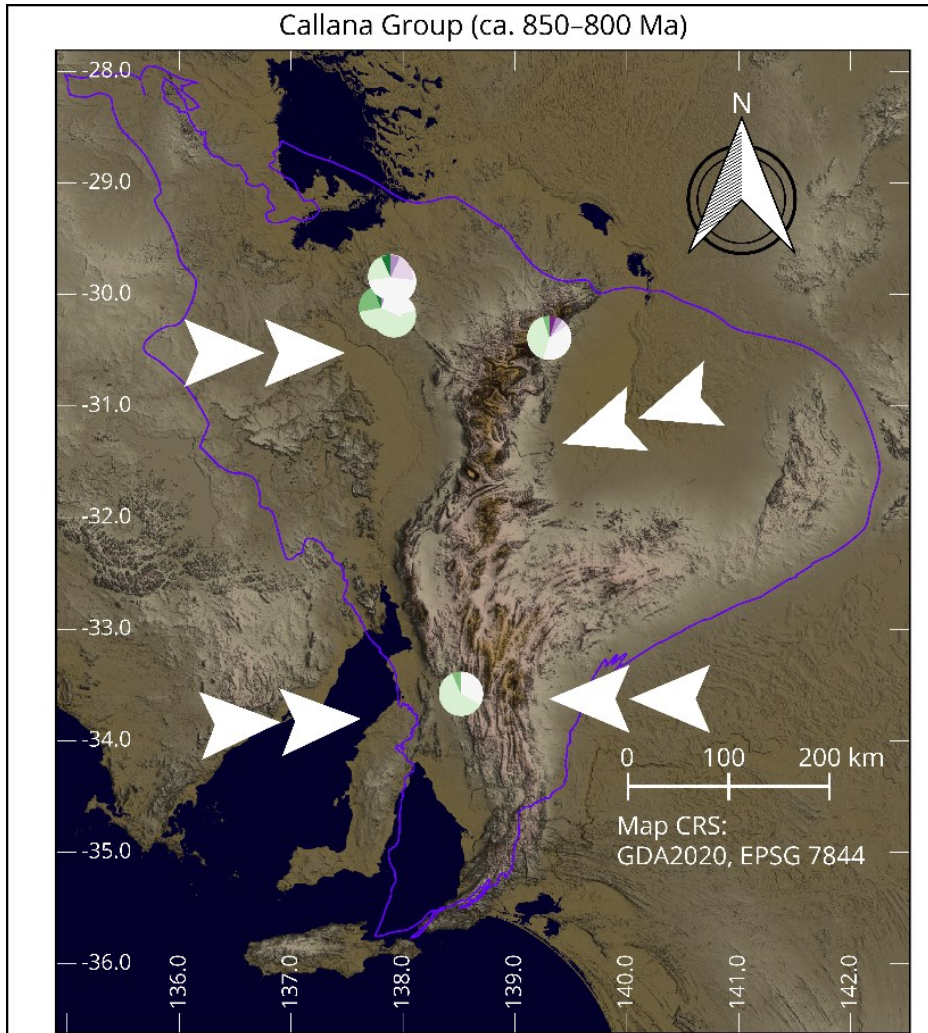

Umberatana Group (ca. 720-630 Ma)

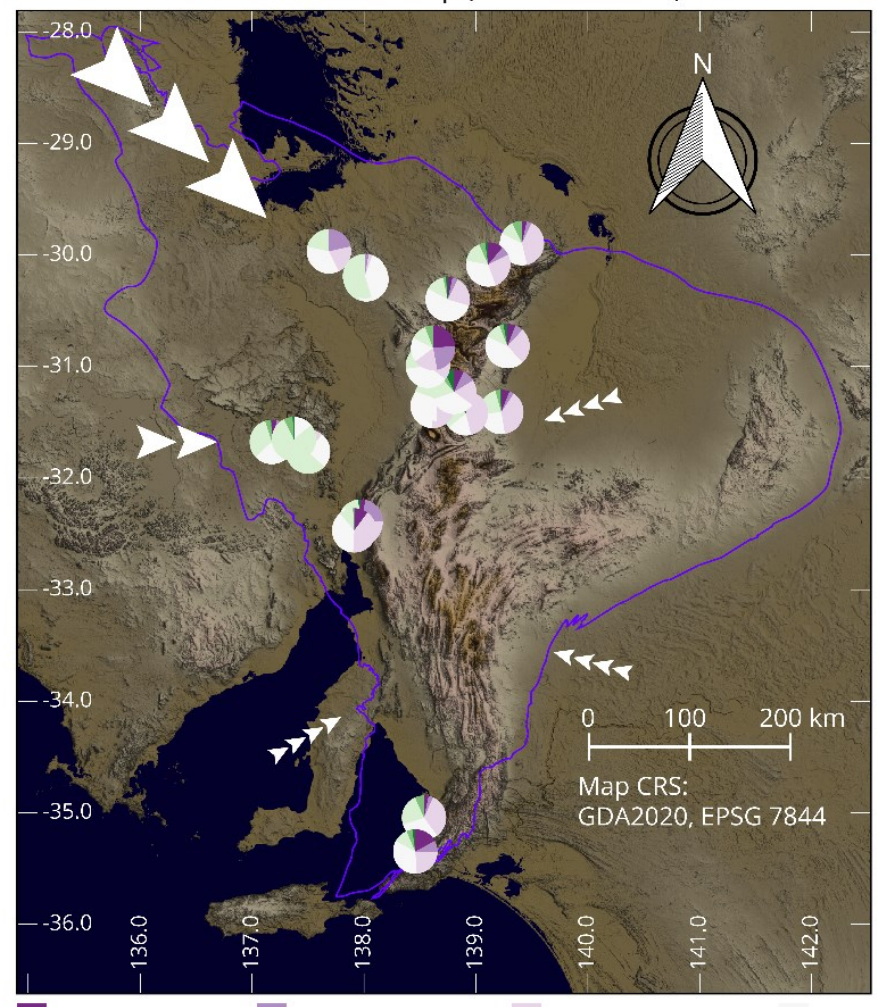

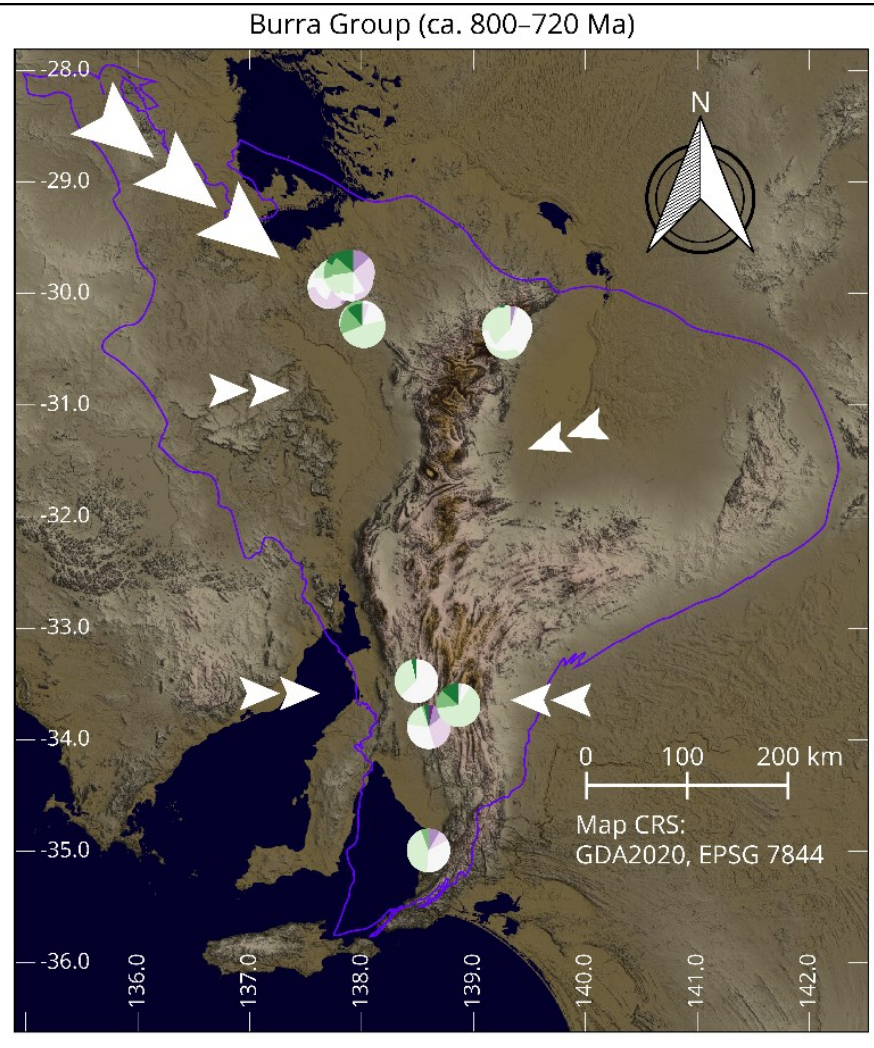

Wilpena Group (ca. 630-541 Ma)

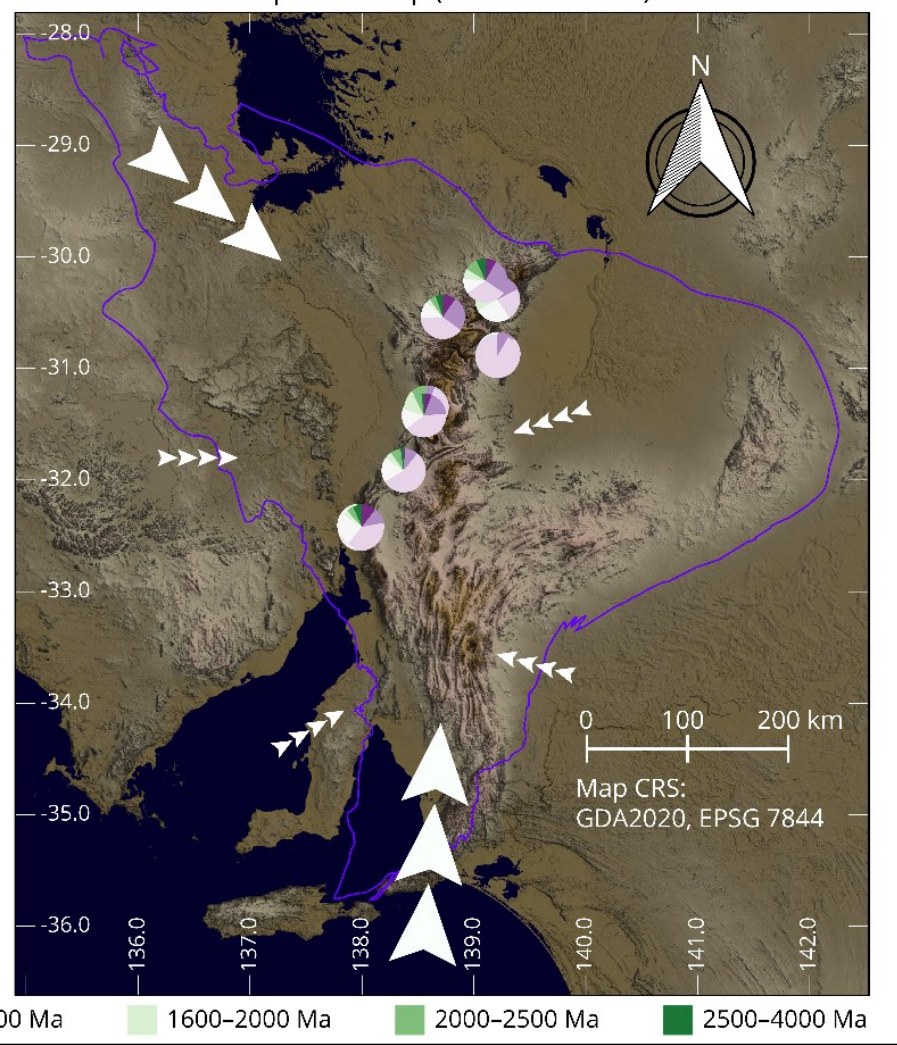


This accepted manuscript is a post-print version made available as per Elsevier's sharing policy under a CC-BY-NC-ND license. The final peer reviewed publication in Precambrian Research can be found at https://doi.org/10.1016/i.precamres.2020.105849

1071 Figure 11 -Generalised overview of provenance change through the Neoproterozoic for the Adelaide Rift Superbasin based on the reconstruction in Figure 5. Sediment was mainly sourced locally (Gawler Craton, Curnamona Province, and possibly Laurentian equivalents) from the rift shoulders during the early development of the basin in the middle Tonian ca. 850 Ma. Just prior to the Sturtian Glaciation (ca. 720) there is a subtle change toward a younger Mesoproterozoic population [see Figure 9]. The Sturtian glacial deposits represent a return to more locally derived sources; but, are followed by a rapid change toward the younger Mesoproterozoic population, attributed to being derived from the Musgrave Province. Up stratigraphy in the Ediacaran there is a subtle shift in the young Mesoproterozoic population that coincides with and increasing population of young zircon (<ca. $740 \mathrm{Ma}$ ) that we suggest may come from southern (Antarctic) sources. Pie charts show counts of age groups within a sample. Arrows show generalised sediment pathways, with their size indicating relative predominance.

The early Mesoproterozoic zircons diminish to minor amounts in the Ediacaran formations of the Adelaide

Superbasin, whereas the late Mesoproterozoic population becomes dominant [Figure 9]. Early

Neoproterozoic and near syndepositional aged zircons also increase in prevalence both suggesting differing detrital sources from the older formations of the Adelaide Superbasin, a detail reflected well in the MDS plots [Figure 10].

The source of the latest Tonian to Ediacaran zircon remains enigmatic. Interestingly, rare Eo- to zircon of these ages has been found in local source terranes. There is also a slight shift in the peak of the late Mesoproterozoic populations from ca. 1180 Ma to ca. 1090 Ma in the youngest Ediacaran Formations [Figure and younger ca. 1050-1000 Ma zircons remains undetermined. More U-Pb detrital zircon data, in combination with $\mathrm{Lu}-\mathrm{Hf}$ and other rare earth and trace element data should help to identify this source. A likely possibility is that this Ediacaran shift in source relates to the introduction of southerly-derived [Figure

1094 (Cottle \& Cooper 2006; Encarnación \& Grunow 1996) which continues into the Palaeozoic and becomes the 1095 dominant source for many of the sediments that make up the Terra Australis Orogen through eastern 1096 Australia (Cawood 2005; Shaanan et al. 2018; Squire \& Wilson 2005).

1097 Our findings largely support the big picture conclusions of previous provenance studies (Haines et al. 2004; 1098 Keeman et al. 2020; Mackay 2011; Rose et al. 2013; Turner et al. 1993b) and palaeogeographic evolution 1099 models (Powell et al. 1994; Preiss 1987; 2000; Turner et al. 1993b), including the development of rift 1100 shoulders during the Cryogenian glaciations. However, the detail now presented illuminates the source-to1101 sink evolution of the Adelaide Superbasin and provides a high-resolution temporal and tectono-geographic 
This accepted manuscript is a post-print version made available as per Elsevier's sharing policy under a CC-BY-NC-ND license. The final peer reviewed publication in Precambrian Research can be found at https://doi.org/10.1016/i.precamres.2020.105849

1102 framework of the region in hitherto unprecedented detail. In particular, the integration of basin evolution and 1103 focussing of northern-derived sediment distribution through the Tonian, followed by the effect of the Sturtian 1104 glaciation on sediment sourcing directly followed by the beginning of southern sources is demonstrated here 1105 in considerably more detail than previous studies have managed.

\section{6. Conclusions}

1107 This paper presents the most comprehensive and only centralised database of both previously unpublished 1108 and published detrital zircon geochronology for the Neoproterozoic of the Adelaide Superbasin, a key

1109 Neoproterozoic basin. Although this data set is large it covers only 27 formations of the 143 formations in the 1110 Neoproterozoic of the Adelaide Superbasin, many of which would be suitable for detrital zircon or whole rock 1111 geochronology. Within the entire filtered dataset presented here, approximately $70 \%$ comes from six 1112 formations and many of the formations have fewer than 100 filtered analyses. Because of this, provenance 1113 tracing and source-to-sink analysis is necessarily rudimentary, but we see this developing rapidly from this 1114 framework in future years with additional data and data from other provenance techniques, such as zircon $1115 \mathrm{Lu}-\mathrm{Hf}$, zircon rare earth element data and other mineral chemical data. Maximum depositional ages are 1116 summarised and broad provenance constraints for the formations have been made whilst acknowledging the 1117 limits of the current data.

1118 This research provides a comprehensive provenance study for the entire basin, with data used to interpret a 1119 broad evolution of the rift system over time. Initial sediment was sourced locally from the rift shoulders (the 1120 Gawler Craton and Curnamona Province). Later, development of the rift basin led to sediment being axially 1121 sourced from far field sources that are inferred to be the Musgrave Province. The Sturtian glaciation saw a 1122 short-lived increase in local derivation, presumably as topography was eroded by the widespread ice cover. 1123 The Ediacaran shift in late Mesoproterozoic population zircon ages, introduction of Neoproterozoic zircons 1124 and rare Eoarchaean/Palaeoarchaean populations are used to suggest a switch to Antarctic sources that 1125 became dominant in the Palaeozoic.

1126 This study presents a framework for future work into the understanding of the age, provenance, and 1127 sedimentary pathways for this vast basin. It identifies data gaps in the geochronological and provenance 
This accepted manuscript is a post-print version made available as per Elsevier's sharing policy under a CC-BY-NC-ND license. The final peer reviewed publication in Precambrian Research can be found at https://doi.org/10.1016/j.precamres.2020.105849

1128 framework for the Neoproterozoic of the Adelaide Superbasin and forms the basis for continuing research

1129 into the palaeo-tectonic geography of the Adelaide Superbasin. Further, this framework will provide

1130 invaluable information for the continuing research of this key Neoproterozoic basin regarding the globally

1131 momentous events it records, their timing and global correlations.

\section{CRediT author statement}

1133 Jarred C. Lloyd: Conceptualisation, investigation, writing - original draft, writing - review \& editing, 1134 methodology, formal analysis, data curation, visualisation. Morgan L. Blades: Writing - original draft, writing 1135 - review \& editing, investigation, visualisation. John W. Counts: Writing - review \& editing, conceptualisation, 1136 investigation. Alan S. Collins: Conceptualisation, funding acquisition, supervision, writing - review \& editing, 1137 Kathryn J. Amos: Conceptualisation, supervision, writing - review \& editing. Benjamin P. Wade:

1138 Investigation, writing - review \& editing. James W. Hall: Investigation Stephen Hore: Investigation.

1139 Ashleigh L. Ball: Investigation. Sameh Shahin: Investigation. Matthew Drabsch: Investigation. Alexander 1140 Prohoroff: Investigation.

\section{Acknowledgements}

1142 We acknowledge that this research is conducted on the ancestral lands for the Adnyamathanha, Arabana, 1143 Banggarla, Kaurna, Kothaka, Kuyani, Ngadjuri and Nukunu Peoples. We acknowledge and respect their deep 1144 feelings of attachment and spiritual relationship to Country, and that their cultural and heritage beliefs are 1145 still as important to the living people today. All efforts are made to obtain permissions from and generate a 1146 dialogue with the traditional custodians of the areas in which we work. This work is conducted with the 1147 relevant permissions and scientific permits from the relevant stakeholders.

1148 We are extremely grateful to Erin Martin and a second anonymous reviewer, as well as associate editor Tony 1149 Kemp for their thoughtful, detailed, and constructive criticisms on the original manuscript. This publication 1150 has been greatly strengthened as a result. 
This accepted manuscript is a post-print version made available as per Elsevier's sharing policy under a CC-BY-NC-ND license. The final peer reviewed publication in Precambrian Research can be found at https://doi.org/10.1016/j.precamres.2020.105849

1151 The authors acknowledge the instruments and scientific and technical assistance of Microscopy Australia at

1152 Adelaide Microscopy, The University of Adelaide, a facility that is funded by the University, and State and

1153 Federal Governments.

1154 We also thank Dr Wolfgang Preiss for his expertise on the Adelaide Superbasin, and the Geological Survey of 1155 South Australia and the MinEx Cooperative Research Centre for funding the continuing work. This is MinEx

1156 CRC publication \#2020/19.

1157

1158

1159

1160

1161

1162

1163

1164

\section{Funding}

This work was supported by the Geological Survey of South Australia and the MinEx CRC.

\section{Data Availability}

Data for this publication is hosted on Figshare, Lloyd et al. (2020),

https://doi.org/10.6084/m9.figshare.11806179.v4. This dataset contains all the U-Pb geochronology data and basic sample details, including geographic coordinates, used in this study.

Updated, detailed stratigraphic correlations for the Neoproterozoic sequences of the Adelaide Superbasin can be found at https://doi.org/10.6084/m9.figshare.11812047 (Lloyd 2020)

Whilst these datasets will be maintained and updated with new data version all previous versions will remain available.

\section{References}

Armit, RJ, Betts, PG, Schaefer, BF, Pankhurst, MJ \& Giles, D 2014, 'Provenance of the Early Mesoproterozoic Radium Creek Group in the northern Mount Painter Inlier: Correlating isotopic signatures to inform tectonic reconstructions', Precambrian Research, vol. 243, 2014/04/01/, pp. 63-87, DOI: 10.1016/j.precamres.2013.12.022.

Bao, H, Lyons, JR \& Zhou, C 2008, 'Triple oxygen isotope evidence for elevated CO2 levels after a Neoproterozoic glaciation', Nature, vol. 453, no. 7194, 2008/05/01, pp. 504-506, DOI: 10.1038/nature06959.

Barovich, KM \& Foden, J 2000, 'A Neoproterozoic flood basalt province in southern-central Australia: geochemical and $\mathrm{Nd}$ isotope evidence from basin fill', Precambrian Research, vol. 100, no. 1, 2000/03/01/, pp. 213-234, DOI: 10.1016/S0301-9268(99)00075-3.

Barovich, KM \& Hand, M 2008, 'Tectonic setting and provenance of the Paleoproterozoic Willyama Supergroup, Curnamona Province, Australia: Geochemical and Nd isotopic constraints on contrasting source terrain components', Precambrian Research, vol. 166, no. 1, 2008/10/30/, pp. 318-337, DOI: 10.1016/j.precamres.2007.06.024. 
This accepted manuscript is a post-print version made available as per Elsevier's sharing policy under a CC-BY-NC-ND license. The final peer reviewed publication in Precambrian Research can be found at https://doi.org/10.1016/i.precamres.2020.105849

Belousova, EA, Reid, AJ, Griffin, WL \& O'Reilly, SY 2009, 'Rejuvenation vs. recycling of Archean crust in the Gawler Craton, South Australia: Evidence from U-Pb and $\mathrm{Hf}$ isotopes in detrital zircon', Lithos, vol. 113, no. 3-4, pp. 570-582, DOI: 10.1016/j.lithos.2009.06.028.

Betts, MJ, Paterson, JR, Jacquet, SM, Andrew, AS, Hall, PA, Jago, JB, Jagodzinski, EA, Preiss, WV, Crowley, JL, Brougham, T, Mathewson, CP, García-Bellido, DC, Topper, TP, Skovsted, CB \& Brock, GA 2018, 'Early Cambrian chronostratigraphy and geochronology of South Australia', Earth-Science Reviews, vol. 185, Oct, pp. 498-543, DOI: 10.1016/j.earscirev.2018.06.005.

Black, LP 2007, SHRIMP U-Pb zircon ages obtained during 2006/07 for NSW Geological Survey Projects, no. GS2007/298.

Black, LP, Williams, IS \& Compston, W 1986, 'Four zircon ages from one rock: the history of a 3930 Ma-old granulite from Mount Sones, Enderby Land, Antarctica', Contributions to Mineralogy and Petrology, vol. 94, no. 4, 1986/12/01, pp. 427-437, DOI: 10.1007/BF00376336.

Blewett, RS, Kennett, BL \& Huston, DL 2012, 'Australia in time and space', in RS Blewett (ed.), Shaping a Nation: A Geology of Australia, Geoscience Australia and ANU E Press, Canberra, Australia, pp. 47117.

Boger, SD 2011, 'Antarctica - Before and after Gondwana', Gondwana Research, vol. 19, no. 2, 2011/03/01/, pp. 335-371, DOI: 10.1016/j.gr.2010.09.003.

Brasier, M \& Lindsay, J 2001, 'Did Supercontinental Amalgamation Trigger the "Cambrian Explosion"?', in AY Zhuralev \& R Riding (eds), The Ecology of the Cambrian Radiation, Columbia University Press, New York, pp. 66-89.

Brocks, JJ 2018, 'The transition from a cyanobacterial to algal world and the emergence of animals', Emerging Topics in Life Sciences, vol. 2, no. 2, pp. 181-190, DOI: 10.1042/etls20180039.

Brocks, JJ, Jarrett, AJM, Sirantoine, E, Hallmann, C, Hoshino, Y \& Liyanage, T 2017, 'The rise of algae in Cryogenian oceans and the emergence of animals', Nature, vol. 548, no. 7669, Aug 31, pp. 578-581, DOI: $10.1038 /$ nature23457.

Brookfield, ME 1993, 'Neoproterozoic Laurentia-Australia fit', Geology, vol. 21, no. 8, pp. 683-686, DOI: 10.1130/0091-7613(1993)021<0683:NLAF>2.3.CO;2.

Callen, RA 1990, Curnamona, 1:250 000 Geological Series-Explanatory Notes, Department of Mines and Energy, Adelaide, South Australia.

Campbell, IH \& Squire, RJ 2010, 'The mountains that triggered the Late Neoproterozoic increase in oxygen: The Second Great Oxidation Event', Geochimica et Cosmochimica Acta, vol. 74, no. 15, Aug 1, pp. 4187-4206, DOI: 10.1016/j.gca.2010.04.064.

Cawood, PA 2005, 'Terra Australis Orogen: Rodinia breakup and development of the Pacific and Iapetus margins of Gondwana during the Neoproterozoic and Paleozoic', Earth-Science Reviews, vol. 69, no. 3, 2005/03/01/, pp. 249-279, DOI: 10.1016/j.earscirev.2004.09.001.

Cawood, PA, Hawkesworth, CJ \& Dhuime, B 2012, 'Detrital zircon record and tectonic setting', Geology, vol. 40, no. 10, Oct, pp. 875-878, DOI: 10.1130/G32945.1.

Cawood, PA \& Korsch, RJ 2008, 'Assembling Australia: Proterozoic building of a continent', Precambrian Research, vol. 166, no. 1, 2008/10/30/, pp. 1-35, DOI: 10.1016/j.precamres.2008.08.006.

Cawood, PA, Wang, W, Zhao, T, Xu, Y, Mulder, JA, Pisarevsky, SA, Zhang, L, Gan, C, He, H, Liu, H, Qi, L, Wang, Y, Yao, J, Zhao, G, Zhou, M-F \& Zi, J-W 2020, 'Deconstructing South China and consequences for reconstructing Nuna and Rodinia', Earth-Science Reviews, vol. 204, 2020/05/01/, p. 103169, DOI: 10.1016/j.earscirev.2020.103169.

Coats, RP \& Blissett, AH 1971, Regional and Economic Geology of the Mount Painter Province, Bulletin, 43, Geological Survey of South Australia, Adelaide, South Australia.

Compston, W, Crawford, AR \& Bofinger, VM 1966, 'A radiometric estimate of the duration of sedimentation in the Adelaide geosyncline, south Australia', Journal of the Geological Society of Australia, vol. 13, no. 1, 1966/01/01, pp. 229-276, DOI: 10.1080/00167616608728611.

Compston, W, Williams, IS, Jenkins, RJF, Gostin, VA \& Haines, PW 1987, 'Zircon Age Evidence for the Late Precambrian Acraman Ejecta Blanket', Australian Journal of Earth Sciences, vol. 34, no. 4, Dec, pp. 435-445, DOI: 10.1080/08120098708729424. 
This accepted manuscript is a post-print version made available as per Elsevier's sharing policy under a CC-BY-NC-ND license. The final peer reviewed publication in Precambrian Research can be found at https://doi.org/10.1016/i.precamres.2020.105849

1233

1234

1235

1236

1237

1238

1239

1240

1241

1242

1243

1244

1245

1246

1247

1248

1249

1250

1251

1252

1253

1254

1255

1256

1257

1258

1259

1260

1261

1262

1263

1264

1265

1266

1267

1268

1269

1270

1271

1272

1273

1274

1275

1276

1277

1278

1279

1280

1281

1282

1283

1284
Condon, D, Zhu, M, Bowring, SA, Wang, W, Yang, A \& Jin, Y 2005, 'U-Pb ages from the neoproterozoic Doushantuo Formation, China', Science, vol. 308, no. 5718, Apr 1, pp. 95-98, DOI: 10.1126/science.1107765.

Cooper, JA, Jenkins, RJF, Compston, W \& Williams, IS 1992, 'Ion-Probe Zircon Dating of a Mid-Early Cambrian Tuff in South-Australia', Journal of the Geological Society, vol. 149, no. 2, Mar, pp. 185192, DOI: $10.1144 /$ gsjgs.149.2.0185.

Cooper, PF, Tuckwell, KD, Gilligan, LB \& Meares, RMD 1974, Geology of the Torrowangee and Fowlers Gap 1:100,000 Sheets, Geological Survey of New South Wales, Department of Mines, Sydney, New South Wales.

Cottle, JM \& Cooper, AF 2006, 'The Fontaine Pluton: An early Ross Orogeny calc - alkaline gabbro from southern Victoria Land, Antarctica', New Zealand Journal of Geology and Geophysics, vol. 49, no. 2, 2006/06/01, pp. 177-189, DOI: 10.1080/00288306.2006.9515158.

Counts, JW 2016, 'Sedimentology, provenance, and salt-sediment interaction in the Ediacaran Pound subgroup, Flinders Ranges, South Australia', Australian School of Petroleum, Doctor of Philosophy thesis, Doctor of Philosophy thesis, The University of Adelaide, Adelaide, South Australia, viewed 4/09/2018, <http://hdl.handle.net/2440/105869>.

Counts, JW 2017, The Adelaide Rift Complex in the Flinders Ranges: geologic history, past investigations and relevant analogues, Report Book, no. 2017/00016, Geological Survey of South Australia, Department of Premier and Cabinet, Adelaide, South Australia,

$<$ https://sarigbasis.pir.sa.gov.au/WebtopEw/ws/samref/sarig1/wcir/Record?r=0\&m=1\&w=catno=20 39731>.

Counts, JW \& Amos, KJ 2016, 'Sedimentology, depositional environments and significance of an Ediacaran salt-withdrawal minibasin, Billy Springs Formation, Flinders Ranges, South Australia', Sedimentology, vol. 63, no. 5, 2016/08/01, pp. 1084-1123, DOI: 10.1111/sed.12250.

Cox, GM, Halverson, GP, Stevenson, RK, Vokaty, M, Poirier, A, Kunzmann, M, Li, Z-X, Denyszyn, SW, Strauss, JV \& Macdonald, FA 2016, 'Continental flood basalt weathering as a trigger for Neoproterozoic Snowball Earth', Earth and Planetary Science Letters, vol. 446, Jul 15, pp. 89-99, DOI: 10.1016/j.epsl.2016.04.016.

Cox, GM, Isakson, V, Hoffman, PF, Gernon, TM, Schmitz, MD, Shahin, S, Collins, AS, Preiss, WV, Blades, ML, Mitchell, RN \& Nordsvan, A 2018, 'South Australian U-Pb zircon (CA-ID-TIMS) age supports globally synchronous Sturtian deglaciation', Precambrian Research, vol. 315, Sep, pp. 257-263, DOI: 10.1016/j.precamres.2018.07.007.

Crawford, AJ \& Hillyard, D 1990, 'Geochemistry of Late Proterozoic tholeiitic flood basalts, Adelaide Geosyncline, South Australia', in JB Jago \& PS Moore (eds), The Evolution of a Late Precambrian Early Palaeozoic Rift Complex: The Adelaide Geosyncline, Geological Society of Australia Inc., Sydney, New South Wales, pp. 49-67.

Dalgarno, CR 1964, 'Lower Cambrian Stratigraphy of the Flinders Ranges', Transactions of the Royal Society of South Australia, vol. 88, pp. 129-144, https://www.biodiversitylibrary.org/item/127587\#page/146/mode/1up.

Daly, SJ, Fanning, CM \& Fairclough, MC 1998, 'Tectonic evolution and exploration potential of the Gawler Craton, South Australia', AGSO Journal of Australian Geology and Geophysics, vol. 17, no. 3, pp. 145168, http://pid.geoscience.gov.au/dataset/ga/81513.

Dalziel, IWD 1991, 'Pacific margins of Laurentia and East Antarctica-Australia as a conjugate rift pair: Evidence and implications for an Eocambrian supercontinent', Geology, vol. 19, no. 6, pp. 598-601, DOI: 10.1130/0091-7613(1991)019<0598:PMOLAE>2.3.CO;2.

Dalziel, IWD 2013, 'Antarctica and supercontinental evolution: clues and puzzles', Earth and Environmental Science Transactions of the Royal Society of Edinburgh, vol. 104, no. 1, pp. 3-16, DOI: 10.1017/S1755691012000096.

Dempster, TJ, Rogers, G, Tanner, PWG, Bluck, BJ, Muir, RJ, Redwood, SD, Ireland, TR \& Paterson, BA 2002, 'Timing of deposition, orogenesis and glaciation within the Dalradian rocks of Scotland: constraints from U-Pb zircon ages', Journal of the Geological Society, vol. 159, no. 1, pp. 83-94, DOI: 10.1144/0016-764901061. 
This accepted manuscript is a post-print version made available as per Elsevier's sharing policy under a CC-BY-NC-ND license. The final peer reviewed publication in Precambrian Research can be found at https://doi.org/10.1016/j.precamres.2020.105849

1285

1286

1287

1288

1289

1290

1291

1292

1293

1294

1295

1296

1297

1298

1299

1300

1301

1302

1303

1304

1305

1306

1307

1308

1309

1310

1311

1312

1313

1314

1315

1316

1317

1318

1319

1320

1321

1322

1323

1324

1325

1326

1327

1328

1329

1330

1331

1332

1333

1334

1335

Dickinson, WR \& Gehrels, GE 2009, 'Use of U-Pb ages of detrital zircons to infer maximum depositional ages of strata: A test against a Colorado Plateau Mesozoic database', Earth and Planetary Science Letters, vol. 288, no. 1-2, 2009/10/30/, pp. 115-125, DOI: 10.1016/j.epsl.2009.09.013.

Direen, NG \& Crawford, AJ 2003, 'The Tasman Line: Where is it, what is it, and is it Australia's Rodinian breakup boundary?', Australian Journal of Earth Sciences, vol. 50, no. 4, 2003/08/01, pp. 491-502, DOI: 10.1046/j.1440-0952.2003.01005.x.

Drabsch, M 2016, 'Structure, Sedimentology and Detrital Zircon U-Pb Analysis of Burra Group Rocks in the Southern Willouran Ranges', School of Physical Sciences, Honours thesis, B.Sc.(Hons) thesis, University of Adelaide, Adelaide, South Australia, viewed 4/09/2018, <http://hdl.handle.net/2440/120896>.

Drexel, JF 2009, Review of the Burra Mine Project, 1980-2008 - a progress report, Report Book, no. RB 2008/00016, Department of Primary Industries and Resources South Australia, Adelaide, South Australia, <https://sarigbasis.pir.sa.gov.au/WebtopEw/ws/samref/sarig1/wci/Record?r=0\&m=1\&w=catno=20 26195>.

Drexel, JF \& McCallum, WS 1986, 'Origin and age of the Burra copper orebody', Quarterly Geological Notes, vol. 98, https://sarigbasis.pir.sa.gov.au/WebtopEw/ws/samref/sarig1/wci/Record?r=0\&m=1\&w=catno=204 1443.

Drexel, JF \& Preiss, WV (eds) 1995, The geology of South Australia, vol. 2, The Phanerozoic, Bulletin, 54, Geological Survey of South Australia, South Australia.

Drexel, JF, Preiss, WV \& Parker, AJ (eds) 1993, The geology of South Australia, vol. 1, The Precambrian, Bulletin, 54, Geological Survey of South Australia, South Australia.

Droser, ML \& Gehling, JG 2015, 'The advent of animals: The view from the Ediacaran', Proceedings of the National Academy of Sciences, vol. 112, no. 16, p. 4865, DOI: $10.1073 /$ pnas.1403669112.

Edgoose, CJ 2013, 'Chapter 23: Amadeus Basin', in M Ahmad \& TJ Munson (compilers), Geology and mineral resources of the Northern Territory, Special Publication 5, Northern Territory Geological Survey, Northern Territory.

Eglington, B 2018, FitPDF (Version 2.3.6808.29738), Software, EggSoft, Canada, viewed 22-August-2018, <http://sil.usask.ca/Eglington/bme_software.htm>.

Elburg, MA, Bons, PD, Dougherty-Page, J, Janka, CE, Neumann, N \& Schaefer, BF 2001, 'Age and metasomatic alteration of the Mt Neill Granite at Nooldoonooldoona Waterhole, Mt Painter Inlier, South Australia', Australian Journal of Earth Sciences, vol. 48, no. 5, 2001/10/01, pp. 721-730, DOI: 10.1046/j.1440-0952.2001.485890.x.

Encarnación, J \& Grunow, A 1996, 'Changing magmatic and tectonic styles along the paleo-Pacific margin of Gondwana and the onset of early Paleozoic magmatism in Antarctica', Tectonics, vol. 15, no. 6, 1996/12/01, pp. 1325-1341, DOI: 10.1029/96TC01484.

Fabris, AJ, Constable, SA, Conor, CHH, Woodhouse, A, Hore, SB \& Fanning, M 2005, 'Age, origin, emplacement and mineral potential of the Oodla Wirra Volcanics, Nackara Arc, central Flinders Ranges', MESA Journal, vol. 37, pp. 44-52,

https://sarigbasis.pir.sa.gov.au/WebtopEw/ws/samref/sarig1/wci/Record?r=0\&m=1\&w=catno=202 5119.

Fanning, CM \& Link, PK 2006, 'Constraints on the timing of the Sturtian Glaciation from Southern Australia; IE for the true Sturtian', in 2006 Philadelphia Annual Meeting, vol. 7, Geological Society of America, Pennsylvania, p. 115.

Fanning, CM, Ludwig, KR, Forbes, BG \& Preiss, WV 1986, 'Single and multiple grain U-Pb zircon analyses for the early Adelaidean Rook Tuff, Willouran Ranges, South Australia', in Eighth Australian Geological Convention: "Earth Resources in Space and Time", Geological Society of Australia, Sydney, New South Wales, pp. 71-72.

Fanning, CM, Reid, AJ \& Teale, GS 2007, A geochronological framework for the Gawler Craton, South Australia, Bulletin, 55, Geological Survey of South Australia, Adelaide, South Australia. 
This accepted manuscript is a post-print version made available as per Elsevier's sharing policy under a CC-BY-NC-ND license. The final peer reviewed publication in Precambrian Research can be found at https://doi.org/10.1016/i.precamres.2020.105849

Fitzsimons, ICW 2000, 'Grenville-age basement provinces in East Antarctica: Evidence for three separate collisional orogens', Geology, vol. 28, no. 10, pp. 879-882, DOI: 10.1130/00917613(2000) $28<879:$ GBPIEA>2.0.CO;2.

Foden, JD, Elburg, MA, Dougherty-Page, J \& Burtt, A 2006, 'The timing and duration of the Delamerian orogeny: Correlation with the Ross Orogen and implications for Gondwana assembly', Journal of Geology, vol. 114, no. 2, Mar, pp. 189-210, DOI: 10.1086/499570.

Foden, JD, Elburg, MA, Turner, S, Clark, C, Blades, ML, Cox, G, Collins, AS, Wolff, K \& George, C 2020, 'Cambro-Ordovician magmatism in the Delamerian orogeny: Implications for tectonic development of the southern Gondwanan margin', Gondwana Research, 2020/01/16/, DOI: 10.1016/j.gr.2019.12.006.

Foden, JD, Sandiford, M, Dougherty-Page, J \& Williams, IS 1999, 'Geochemistry and geochronology of the Rathjen Gneiss: Implications for the early tectonic evolution of the Delamerian Orogen', Australian Journal of Earth Sciences, vol. 46, no. 3, 1999/06/01, pp. 377-389, DOI: 10.1046/j.14400952.1999.00712.x.

Fraser, GL, McAvaney, S, Neumann, NL, Szpunar, M \& Reid, A 2010, 'Discovery of early Mesoarchean crust in the eastern Gawler Craton, South Australia', Precambrian Research, vol. 179, no. 1, 2010/05/01/, pp. 1-21, DOI: 10.1016/j.precamres.2010.02.008.

Fraser, GL \& Neumann, NL (compilers) 2010, New SHRIMP U-Pb Zircon Ages from the Gawler Craton and Curnamona Province, South Australia, 2008 - 2010, Record, Geoscience Australia, Canberra.

Gehling, JG \& Droser, ML 2012, 'Ediacaran stratigraphy and the biota of the Adelaide Geosyncline, South Australia', Episodes, vol. 35, no. 1, pp. 236-246, DOI: 10.18814/epiiugs/2012/v35i1/023.

Gehrels, GE, Butler, RR \& Bazard, DR 1996, 'Detrital zircon geochronology of the Alexander terrane, southeastern Alaska', Geological Society of America Bulletin, vol. 108, no. 6, Jun, pp. 722-734, DOI: 10.1130/0016-7606(1996)108<0722:Dzgota>2.3.Co;2.

Gernon, TM, Hincks, TK, Tyrrell, T, Rohling, EJ \& Palmer, MR 2016, 'Snowball Earth ocean chemistry driven by extensive ridge volcanism during Rodinia breakup', Nature Geoscience, vol. 9, no. 3, 2016/03/01, pp. 242-248, DOI: $10.1038 /$ ngeo2632.

Glaessner, MF 1959, 'The oldest fossil faunas of South Australia', Geologische Rundschau, vol. 47, no. 2, June 01, pp. 522-531, DOI: 10.1007/bf01800671.

Goodge, JW, Vervoort, JD, Fanning, CM, Brecke, DM, Farmer, GL, Williams, IS, Myrow, PM \& DePaolo, DJ 2008, 'A Positive Test of East Antarctica-Laurentia Juxtaposition Within the Rodinia Supercontinent', Science, vol. 321, no. 5886, p. 235, DOI: 10.1126/science.1159189.

Gostin, VA, Haines, PW, Jenkins, RJF, Compston, W \& Williams, IS 1986, 'Impact ejecta horizon within late Precambrian shales, Adelaide geosyncline, South Australia', Science, vol. 233, p. 198, https://science.sciencemag.org/content/233/4760/198.long.

Gradstein, FM, Ogg, JG \& Smith, AG (eds) 2005, A Geologic Time Scale 2004, Cambridge University Press, Cambridge.

Grazhdankin, D 2004, 'Patterns of distribution in the Ediacaran biotas: facies versus biogeography and evolution', Paleobiology, vol. 30, no. 2, pp. 203-221, DOI: 10.1666/00948373(2004)030<0203:Podite>2.0.Co;2.

Greenfield, JE \& Mills, KJ 2010, 'Neoproterozoic', in JE Greenfield, PJ Gilmore \& KJ Mills (eds), Explanatory notes for the Koonenberry geological maps, no. 35, Geological Survey of New South Wales, Sydney, New South Wales, Australia, pp. 13-30.

Gum, JC 1987, 'Geochemistry of the mafic igneous rocks found in Enorama Diapir, central Flinders Ranges, and their relationship to similar rocks found in nearby diapirs and volcanic bodies throughout the Flinders Ranges', School of Physical Sciences, Honours thesis, B.Sc(Hons) thesis, The University of Adelaide, Adelaide, South Australia, <http://hdl.handle.net/2440/112230>.

Haines, PW, Turner, SP, Foden, JD \& Jago, JB 2009, 'Isotopic and geochemical characterisation of the Cambrian Kanmantoo Group, South Australia: implications for stratigraphy and provenance', Australian Journal of Earth Sciences, vol. 56, no. 8, 2009/12/01, pp. 1095-1110, DOI: 10.1080/08120090903246212.

Haines, PW, Turner, SP, Kelley, SP, Wartho, J-A \& Sherlock, SC 2004, '40Ar-39Ar dating of detrital muscovite in provenance investigations: a case study from the Adelaide Rift Complex, South 
This accepted manuscript is a post-print version made available as per Elsevier's sharing policy under a CC-BY-NC-ND license. The final peer reviewed publication in Precambrian Research can be found at https://doi.org/10.1016/i.precamres.2020.105849

Australia', Earth and Planetary Science Letters, vol. 227, no. 3, 2004/11/15/, pp. 297-311, DOI: 10.1016/j.epsl.2004.08.020.

Halverson, GP, Hurtgen, MT, Porter, SM \& Collins, AS 2009, 'Chapter 10 Neoproterozoic-Cambrian Biogeochemical Evolution', in C Gaucher, AN Sial, HE Frimmel \& GP Halverson (eds), Developments in Precambrian Geology, vol. 16, Elsevier, pp. 351-365.

Halverson, GP, Porter, SM \& Gibson, TM 2018, 'Dating the late Proterozoic stratigraphic record', Emerging Topics in Life Sciences, vol. 2, no. 2, pp. 137-147, DOI: 10.1042/etls20170167.

Hand, M, Reid, A \& Jagodzinski, L 2007, 'Tectonic Framework and Evolution of the Gawler Craton, Southern Australia', Economic Geology, vol. 102, no. 8, pp. 1377-1395, DOI: 10.2113/gsecongeo.102.8.1377.

Harley, SL \& Kelly, NM 2007, 'Chapter 3.2 Ancient Antarctica: The Archaean of the East Antarctic Shield', in MJ van Kranendonk, RH Smithies \& VC Bennett (eds), Developments in Precambrian Geology, vol. 15, Elsevier, pp. 149-186.

Hillyard, D 1990, 'Willouran Basic Province: Stratigraphy of Late Proterozoic flood basalts, Adelaide Geosyncline, South Australia', in JB Jago \& PS Moore (eds), The Evolution of a Late Precambrian Early Palaeozoic Rift Complex: The Adelaide Geosyncline, Geological Society of Australia Inc., Sydney, New South Wales, pp. 34-48.

Hoffman, PF 1991, 'Did the Breakout of Laurentia Turn Gondwanaland Inside-Out?', Science, vol. 252, no. 5011, pp. 1409-1412, www.jstor.org/stable/2875916.

Hoffman, PF, Abbot, DS, Ashkenazy, Y, Benn, DI, Brocks, JJ, Cohen, PA, Cox, GM, Creveling, JR, Donnadieu, Y, Erwin, DH, Fairchild, IJ, Ferreira, D, Goodman, JC, Halverson, GP, Jansen, MF, Le Hir, G, Love, GD, Macdonald, FA, Maloof, AC, Partin, CA, Ramstein, G, Rose, BEJ, Rose, CV, Sadler, PM, Tziperman, E, Voigt, A \& Warren, SG 2017, 'Snowball Earth climate dynamics and Cryogenian geology-geobiology', Science Advances, vol. 3, no. 11, p. e1600983, DOI: 10.1126/sciadv.1600983.

Hoffman, PF, Kaufman, AJ, Halverson, GP \& Schrag, DP 1998, 'A Neoproterozoic Snowball Earth', Science, vol. 281, no. 5381, p. 1342, DOI: 10.1126/science.281.5381.1342.

Hoffman, PF \& Li, Z-X 2009, 'A palaeogeographic context for Neoproterozoic glaciation', Palaeogeography Palaeoclimatology Palaeoecology, vol. 277, no. 3-4, Jun 15, pp. 158-172, DOI: 10.1016/j.palaeo.2009.03.013.

Hore, SB 2015, Mount Painter Region geological map, Geological Survey of South Australia, Adelaide, South Australia.

Ireland, TR, Flöttmann, T, Fanning, CM, Gibson, GM \& Preiss, WV 1998, 'Development of the early Paleozoic Pacific margin of Gondwana from detrital-zircon ages across the Delamerian orogen', Geology, vol. 26, no. 3, Mar, pp. 243-246, DOI: 10.1130/0091-7613(1998)026<0243:Dotepp>2.3.Co;2.

Jackson, SE, Pearson, NJ, Griffin, WL \& Belousova, EA 2004, 'The application of laser ablation-inductively coupled plasma-mass spectrometry to in situ U-Pb zircon geochronology', Chemical Geology, vol. 211, no. 1-2, 2004/11/08/, pp. 47-69, DOI: 10.1016/j.chemgeo.2004.06.017.

Jacobs, J, Elburg, MA, Läufer, A, Kleinhanns, IC, Henjes-Kunst, F, Estrada, S, Ruppel, AS, Damaske, D, Montero, P \& Bea, F 2015, 'Two distinct Late Mesoproterozoic/Early Neoproterozoic basement provinces in central/eastern Dronning Maud Land, East Antarctica: The missing link, $15-21^{\circ} \mathrm{E}$ ', Precambrian Research, vol. 265, 2015/08/01/, pp. 249-272, DOI: 10.1016/j.precamres.2015.05.003.

Jagodzinski, EA \& Fricke, CE 2010, Compilation of new SHRIMP U-Pb geochronological data for the Southern Curnamona Province, South Australia, 2010, Report Book, no. 2010/00014, Geological Survey of South Australia, Department of Primary Industries and Resources, Adelaide, South Australia.

Jagodzinski, EA \& McAvaney, SO 2017, SHRIMP U-Pb geochronology data for northern Eyre Peninsula, 20142016, Report Book, no. 2016/00001, Geological Survey of South Australia, Adelaide, South Australia, $<$ https://sarigbasis.pir.sa.gov.au/WebtopEw/ws/samref/sarig1/wci/Record?r=0\&m=1\&w=catno=20 39475>.

Jenkins, RJF, Cooper, JA \& Compston, W 2002, 'Age and biostratigraphy of Early Cambrian tuffs from SE Australia and southern China', Journal of the Geological Society, vol. 159, no. 6, pp. 645-658, DOI: 10.1144/0016-764901-127. 
This accepted manuscript is a post-print version made available as per Elsevier's sharing policy under a CC-BY-NC-ND license. The final peer reviewed publication in Precambrian Research can be found at https://doi.org/10.1016/i.precamres.2020.105849

Job, AL 2011, 'Evolution of the basal Adelaidean in the northern Flinders Ranges: deposition, provenance and deformation of the Callanna and lower Burra Groups', Department of Geology and Geophysics, Honours thesis, B.Sc.(Hons) thesis, University of Adelaide, Adelaide, South Australia, viewed 4/09/2018, <http://hdl.handle.net/2440/96175>.

Karlstrom, KE \& Bowring, SA 1988, 'Early Proterozoic Assembly of Tectonostratigraphic Terranes in Southwestern North America', The Journal of Geology, vol. 96, no. 5, 1988/09/01, pp. 561-576, DOI: $10.1086 / 629252$.

Karlstrom, KE, Harlan, SS, Williams, ML, McLelland, J, Geissman, JW \& Ahäll, K-I 1999, 'Refining Rodinia: geologic evidence for the Australia-western US connection in the Proterozoic', GSA Today, vol. 9, no. 10, pp. 1-7.

Kasemann, SA, Hawkesworth, CJ, Prave, AR, Fallick, AE \& Pearson, PN 2005, 'Boron and calcium isotope composition in Neoproterozoic carbonate rocks from Namibia: evidence for extreme environmental change', Earth and Planetary Science Letters, vol. 231, no. 1, 2005/02/28/, pp. 73-86, DOI: 10.1016/j.epsl.2004.12.006.

Keeman, J, Turner, S, Haines, PW, Belousova, E, Ireland, T, Brouwer, P, Foden, J \& Wörner, G 2020, 'New $\mathrm{UPb}, \mathrm{Hf}$ and $\mathrm{O}$ isotope constraints on the provenance of sediments from the Adelaide Rift ComplexDocumenting the key Neoproterozoic to early Cambrian succession', Gondwana Research, vol. 83, 2020/07/01/, pp. 248-278, DOI: 10.1016/j.gr.2020.02.005.

Kendall, B, Creaser, RA \& Selby, D 2006, 'Re-Os geochronology of postglacial black shales in Australia: Constraints on the timing of "Sturtian" glaciation', Geology, vol. 34, no. 9, pp. 729-732, DOI: $10.1130 / \mathrm{g} 22775.1$.

Knoll, AH \& Carroll, SB 1999, 'Early Animal Evolution: Emerging Views from Comparative Biology and Geology', Science, vol. 284, no. 5423, p. 2129, DOI: 10.1126/science.284.5423.2129.

Knoll, AH \& Walter, MR 1992, 'Latest Proterozoic stratigraphy and Earth history', Nature, vol. 356, no. 6371, 1992/04/01, pp. 673-678, DOI: 10.1038/356673a0.

Knoll, AH, Walter, MR, Narbonne, GM \& Christie-Blick, N 2006, 'The Ediacaran Period: a new addition to the geologic time scale', Lethaia, vol. 39, no. 1, 2006/03/01, pp. 13-30, DOI: 10.1080/00241160500409223.

Lamothe, KG, Hoffman, PF, Greenman, JW \& Halverson, GP 2019, 'Stratigraphy and isotope geochemistry of the pre-Sturtian Ugab Subgroup, Otavi/Swakop Group, northwestern Namibia', Precambrian Research, vol. 332, 2019/09/15/, p. 105387, DOI: 10.1016/j.precamres.2019.105387.

Le Heron, DP, Cox, GM, Trundley, A \& Collins, AS 2011, 'Two Cryogenian glacial successions compared: Aspects of the Sturt and Elatina sediment records of South Australia', Precambrian Research, vol. 186, no. 1, 2011/04/01/, pp. 147-168, DOI: 10.1016/j.precamres.2011.01.014.

Leslie, CD 2009, 'Detrital zircon geochronology and rift-related magmatism: central Mackenzie Mountains, Northwest Territories', Department of Earth, Ocean and Atmospheric Sciences, MSc thesis, Master of Science thesis, University of British Columbia, <http://hdl.handle.net/2429/7109>.

Li, Z-X, Bogdanova, SV, Collins, AS, Davidson, A, De Waele, B, Ernst, RE, Fitzsimons, ICW, Fuck, RA, Gladkochub, DP, Jacobs, J, Karlstrom, KE, Lu, S, Natapov, LM, Pease, V, Pisarevsky, SA, Thrane, K \& Vernikovsky, V 2008, 'Assembly, configuration, and break-up history of Rodinia: A synthesis', Precambrian Research, vol. 160, no. 1-2, Jan 5, pp. 179-210, DOI: 10.1016/j.precamres.2007.04.021.

Li, Z-X \& Evans, DAD 2010, 'Late Neoproterozoic 40 intraplate rotation within Australia allows for a tighterfitting and longer-lasting Rodinia', Geology, vol. 39, no. 1, pp. 39-42, DOI: 10.1130/g31461.1.

Li, Z-X \& Powell, CM 2001, 'An outline of the palaeogeographic evolution of the Australasian region since the beginning of the Neoproterozoic', Earth-Science Reviews, vol. 53, no. 3, 2001/04/01/, pp. 237-277, DOI: $10.1016 /$ S0012-8252(00)00021-0.

Li, Z-X, Zhang, L \& Powell, CM 1995, 'South China in Rodinia: Part of the missing link between Australia-East Antarctica and Laurentia?', Geology, vol. 23, no. 5, pp. 407-410, DOI: 10.1130/00917613(1995)023<0407:SCIRPO>2.3.CO;2.

Liu, DY, Wan, YS, Wu, JS, Wilde, SA, Zhou, HY, Dong, CY \& Yin, XY 2007, 'Chapter 3.5 Eoarchean Rocks and Zircons in the North China Craton', in MJ van Kranendonk, RH Smithies \& VC Bennett (eds), Developments in Precambrian Geology, vol. 15, Elsevier, pp. 251-273. 
This accepted manuscript is a post-print version made available as per Elsevier's sharing policy under a CC-BY-NC-ND license. The final peer reviewed publication in Precambrian Research can be found at https://doi.org/10.1016/j.precamres.2020.105849

[Dataset] Lloyd, JC 2020, Lithostratigraphic Correlation Chart of the Adelaide Superbasin (Neoproterozoic), v. 3, Figshare, Adelaide, South Australia, DOI: 10.6084/m9.figshare.11812047.v3.

[Dataset] Lloyd, JC, Blades, ML, Counts, JW, Collins, AS, Amos, KJ, Wade, BP, Hall, JW, Hore, SB, Ball, AL, Shahin, S \& Drabsch, M 2020, Database of Neoproterozoic U-Pb geochronology and Hf isotopic data for the Adelaide Superbasin, v. 3, Figshare, Adelaide, South Australia, DOI: 10.6084/m9.figshare.11806179.v3.

Mackay, WG 2011, 'Structure and sedimentology of the Curdimurka Subgroup, northern Adelaide Fold Belt, South Australia', Doctor of Philosophy thesis, Doctor of Philosophy thesis, University of Tasmania, Hobart, Tasmania, viewed 4/09/2018, <https://eprints.utas.edu.au/12486/>.

MacLennan, S, Park, Y, Swanson-Hysell, N, Maloof, A, Schoene, B, Gebreslassie, M, Antilla, E, Tesema, T, Alene, M \& Haileab, B 2018, 'The arc of the Snowball: U-Pb dates constrain the Islay anomaly and the initiation of the Sturtian glaciation', Geology, vol. 46, no. 6, pp. 539-542, DOI: 10.1130/G40171.1.

Mahan, KH, Wernicke, BP \& Jercinovic, MJ 2010, 'Th-U-total Pb geochronology of authigenic monazite in the Adelaide rift complex, South Australia, and implications for the age of the type Sturtian and Marinoan glacial deposits', Earth and Planetary Science Letters, vol. 289, no. 1-2, 2010/01/15/, pp. 76-86, DOI: 10.1016/j.epsl.2009.10.031.

Martin, C 1986, Miandana 1 - well completion report, no. WCR 06491, Delhi Petroleum Pty Ltd, $<$ https://sarigbasis.pir.sa.gov.au/WebtopEw/ws/samref/sarig1/wci/Record?r=0\&m=1\&w=catno=20 28399>.

Maruyama, S \& Santosh, M 2008, 'Models on Snowball Earth and Cambrian explosion: A synopsis', Gondwana Research, vol. 14, no. 1, 2008/08/01/, pp. 22-32, DOI: 10.1016/j.gr.2008.01.004.

Mawson, D \& Sprigg, RC 1950, 'Subdivision of the Adelaide System', Australian Journal of Science, vol. 13, no. 3, pp. 69-72.

McAvaney, S 2012, 'The Cooyerdoo Granite: Paleo- and Mesoarchean basement of the Gawler Craton', MESA Journal, vol. 65, pp. 31-40, https://sarigbasis.pir.sa.gov.au/WebtopEw/ws/samref/sarig1/wci/Record?r=0\&m=1\&w=catno=203 5289.

Meaney, KJ 2012, 'The geochronology and structural evolution of the Warren Inlier and Springfield Sequence, Mt. Lofty Ranges: Implications for Proterozoic paleogeographic reconstructions', School of Earth and Environmental Sciences, Honours thesis, B.Sc(Hons) thesis, The University of Adelaide, Adelaide, South Australia, <http://hdl.handle.net/2440/95177>.

Meaney, KJ 2017, 'Proterozoic Crustal Growth in the Southeastern Gawler Craton; The Development of the Barossa Complex and an Assessment of the Detrital Zircon Method', Department of Geology and Geophysics, Doctor of Philosophy thesis, The University of Adelaide, Adelaide, South Australia.

Meert, JG \& Lieberman, BS 2008, 'The Neoproterozoic assembly of Gondwana and its relationship to the Ediacaran-Cambrian radiation', Gondwana Research, vol. 14, no. 1, 2008/08/01/, pp. 5-21, DOI: 10.1016/j.gr.2007.06.007.

Meffre, S, Direen, NG, Crawford, AJ \& Kamenetsky, V 2004, 'Mafic volcanic rocks on King Island, Tasmania: evidence for 579Ma break-up in east Gondwana', Precambrian Research, vol. 135, no. 3, 2004/11/30/, pp. 177-191, DOI: 10.1016/j.precamres.2004.08.004.

Merdith, AS, Collins, AS, Williams, SE, Pisarevsky, SA, Foden, JD, Archibald, DB, Blades, ML, Alessio, BL, Armistead, SE, Plavsa, D, Clark, C \& Müller, RD 2017a, 'A full-plate global reconstruction of the Neoproterozoic', Gondwana Research, vol. 50, 2017/10/01/, pp. 84-134, DOI: 10.1016/j.gr.2017.04.001.

Merdith, AS, Williams, SE, Collins, AS, Tetley, MG, Mulder, JA, Blades, ML, Young, A, Armistead, SE, Cannon, J, Zahirovic, S \& Müller, RD (submitted), 'A continuous, kinematic full plate motion model from $1 \mathrm{Ga}$ to present', Earth Science Reviews.

Merdith, AS, Williams, SE, Müller, RD \& Collins, AS 2017b, 'Kinematic constraints on the Rodinia to Gondwana transition', Precambrian Research, vol. 299, 2017/09/01/, pp. 132-150, DOI: 10.1016/j.precamres.2017.07.013. 
This accepted manuscript is a post-print version made available as per Elsevier's sharing policy under a CC-BY-NC-ND license. The final peer reviewed publication in Precambrian Research can be found at https://doi.org/10.1016/i.precamres.2020.105849

1545

1546

1547

1548

1549

1550

1551

1552

1553

1554

1555

1556

1557

1558

1559

1560

1561

1562

1563

1564

1565

1566

1567

1568

1569

1570

1571

1572

1573

1574

1575

1576

1577

1578

1579

1580

1581

1582

1583

1584

1585

1586

1587

1588

1589

1590

1591

1592

1593

1594

1595

1596

1597
Miller, RM 2013, 'Comparative Stratigraphic and Geochronological Evolution of the Northern Damara Supergroup in Namibia and the Katanga Supergroup in the Lufilian Arc of Central Africa', Geoscience Canada, vol. 40, no. 2, 08/24, pp. 118 - 140, DOI: 10.12789/geocanj.2013.40.007.

Mills, KJ 1963, 'The geology of the Mount Crawford Granite Gneiss and adjacent metasediments', Transactions of the Royal Society of South Australia, vol. 87, pp. 167-183, https://www.biodiversitylibrary.org/item/127608\#page/186/mode/1up.

Milton, JE, Hickey, KA, Gleeson, SA \& Friedman, RM 2017, 'New U-Pb constraints on the age of the Little Dal Basalts and Gunbarrel-related volcanism in Rodinia', Precambrian Research, vol. 296, 2017/07/01/, pp. 168-180, DOI: 10.1016/j.precamres.2017.04.030.

Moores, EM 1991, 'Southwest U.S.-East Antarctic (SWEAT) connection: A hypothesis', Geology, vol. 19, no. 5 , pp. 425-428, DOI: 10.1130/0091-7613(1991)019<0425:SUSEAS>2.3.CO;2.

Morrissey, LJ, Barovich, KM, Hand, M, Howard, KE \& Payne, JL 2019, 'Magmatism and metamorphism at ca. $1.45 \mathrm{Ga}$ in the northern Gawler Craton: The Australian record of rifting within Nuna (Columbia)', Geoscience Frontiers, vol. 10, no. 1, 2019/01/01/, pp. 175-194, DOI: 10.1016/j.gsf.2018.07.006.

Mulder, JA, Everard, JL, Cumming, G, Meffre, S, Bottrill, RS, Merdith, AS, Halpin, JA, McNeill, AW \& Cawood, PA 2020, 'Neoproterozoic opening of the Pacific Ocean recorded by multi-stage rifting in Tasmania, Australia', Earth-Science Reviews, vol. 201, 2020/02/01/, p. 103041, DOI: 10.1016/j.earscirev.2019.103041.

Munson, TJ, Kruse, PD \& Ahmad, M 2013, 'Chapter 22: Centralian Superbasin', in M Ahmad \& TJ Munson (compilers), Geology and mineral resources of the Northern Territory, Special Publication 5, Northern Territory Geological Survey, Northern Territory.

Myers, JS, Shaw, RD \& Tyler, IM 1996, 'Tectonic evolution of Proterozoic Australia', Tectonics, vol. 15, no. 6, 1996/12/01, pp. 1431-1446, DOI: 10.1029/96TC02356.

Nascimento, DB, Schmitt, RS, Ribeiro, A, Trouw, RAJ, Passchier, CW \& Basei, MAS 2017, 'Depositional ages and provenance of the Neoproterozoic Damara Supergroup (northwest Namibia): Implications for the Angola-Congo and Kalahari cratons connection', Gondwana Research, vol. 52, 2017/12/01/, pp. 153-171, DOI: 10.1016/j.gr.2017.09.006.

Noble, SR, Hyslop, EK \& Highton, AJ 1996, 'High-precision U-Pb monazite geochronology of the c. 806 Ma Grampian Shear Zone and the implications for the evolution of the Central Highlands of Scotland', Journal of the Geological Society, vol. 153, no. 4, pp. 511-514, DOI: 10.1144/gsjgs.153.4.0511.

Nordsvan, AR, Kirscher, U, Kirkland, CL, Barham, M \& Brennan, DT 2020, 'Resampling (detrital) zircon age distributions for accurate multidimensional scaling solutions', Earth-Science Reviews, 2020/03/07/, p. 103149, DOI: 10.1016/j.earscirev.2020.103149.

Page, RW, Stevens, BPJ \& Gibson, GM 2005, 'Geochronology of the Sequence Hosting the Broken Hill Pb-ZnAg Orebody, Australia', Economic Geology, vol. 100, no. 4, pp. 633-661, DOI: 10.2113/gsecongeo.100.4.633.

Paton, C, Hellstrom, J, Paul, B, Woodhead, J \& Hergt, J 2011, 'Iolite: Freeware for the visualisation and processing of mass spectrometric data', Journal of Analytical Atomic Spectrometry, vol. 26, no. 12, pp. 2508-2518, DOI: 10.1039/C1JA10172B.

Payne, JL, Barovich, KM \& Hand, M 2006, 'Provenance of metasedimentary rocks in the northern Gawler Craton, Australia: Implications for Palaeoproterozoic reconstructions', Precambrian Research, vol. 148, no. 3, 2006/08/10/, pp. 275-291, DOI: 10.1016/j.precamres.2006.05.002.

Powell, CM 1998, 'Assembly and Break-up of Rodinia Leading to Formation of Gondwana Land', in RT Bird (ed.), The Assembly and Breakup of Rodinia, Geological Society of Australia, Sydney, New South Wales, pp. 49-53.

Powell, CM, Preiss, WV, Gatehouse, CG, Krapez, B \& Li, Z-X 1994, 'South Australian record of a Rodinian epicontinental basin and its mid-neoproterozoic breakup $(\sim 700 \mathrm{Ma})$ to form the Palaeo-Pacific Ocean', Tectonophysics, vol. 237, no. 3-4, pp. 113-140, DOI: 10.1016/0040-1951(94)90250-x.

Preiss, WV 1982, 'Supergroup classification in the Adelaide Geosyncline', Transactions of the Royal Society of South Australia, vol. 106, pp. 81-83.

Preiss, WV (compiler) 1987, Adelaide Geosyncline-late Proterozoic stratigraphy, sedimentation, palaeontology and tectonics, Bulletin, 53, Geological Survey of South Australia, Adelaide, South Australia.

(c) 2020. This manuscript version is made available under the CC-BY-NC-ND 4.0 license http://creativecommons.org/licenses/by-nc-nd/4.0/ 
This accepted manuscript is a post-print version made available as per Elsevier's sharing policy under a CC-BY-NC-ND license. The final peer reviewed publication in Precambrian Research can be found at https://doi.org/10.1016/i.precamres.2020.105849

Preiss, WV 1988, Stratigraphic and tectonic overview of the Adelaide Geosyncline, South Australia, Report Book, no. 88/00019, Geological Survey of South Australia, Department of Mines and Energy, Adelaide, South Australia, $<$ https://sarigbasis.pir.sa.gov.au/WebtopEw/ws/samref/sarig1/wcir/Record?r=0\&m=1\&w=catno=34 03>.

Preiss, WV 1990, 'A stratigraphic and tectonic overview of the Adelaide Geosyncline, South Australia', in JB Jago \& PS Moore (eds), The Evolution of a Late Precambrian Early Palaeozoic Rift Complex: The Adelaide Geosyncline, Geological Society of Australia Inc., Sydney, New South Wales, pp. 1-33.

Preiss, WV 2000, 'The Adelaide Geosyncline of South Australia and its significance in Neoproterozoic continental reconstruction', Precambrian Research, vol. 100, no. 1-3, Mar, pp. 21-63, DOI: 10.1016/S0301-9268(99)00068-6.

Preiss, WV, Alexander, EM, Cowley, WM \& Schwarz, MP 2002, 'Towards defining South Australia's geological provinces and sedimentary basins', MESA Journal, vol. 27, pp. 39-52.

Preiss, WV \& Cowley, WM 1999, 'Genetic stratigraphy and revised lithostratigraphic classification of the Burra Group in the Adelaide Geosyncline', MESA Journal, vol. 14, July 1999, pp. 30-40, https://sarigbasis.pir.sa.gov.au/WebtopEw/ws/samref/sarig1/wcir/Record?r=0\&m=1\&w=catno=202 5015.

Preiss, WV, Drexel, JF \& Reid, AJ 2009, 'Definition and age of the Kooringa Member of the Skillogalee Dolomite: host for Neoproterozoic (c. $790 \mathrm{Ma}$ ) porphyry related copper mineralisation at Burra', MESA Journal, vol. 55, pp. 19-33, https://sarigbasis.pir.sa.gov.au/WebtopEw/ws/samref/sarig1/wci/Record?r=0\&m=1\&w=catno=202 8895.

Preiss, WV, Dyson, IA, Reid, PW \& Cowley, WM 1998, 'Revision of lithostratigraphic classification of the Umberatana Group', MESA Journal, vol. 9, April 1998, pp. 36-42, https://sarigbasis.pir.sa.gov.au/WebtopEw/ws/samref/sarig1/wcir/Record? $r=0 \& m=1 \& w=c a t n o=202$ 5009.

Preiss, WV, Fanning, CM, Szpunar, MA \& Burtt, AC 2008, 'Age and tectonic significance of the Mount Crawford Granite Gneiss and a related intrusive in the Oakbank Inlier, Mount Lofty Ranges, South Australia', MESA Journal, vol. 49, pp. 38-49, https://sarigbasis.pir.sa.gov.au/WebtopEw/ws/samref/sarig1/wci/Record?r=0\&m=1\&w=catno=202 6080.

Puetz, SJ 2018, 'A relational database of global U-Pb ages', Geoscience Frontiers, vol. 9, no. 3, 2018/05/01/, pp. 877-891, DOI: 10.1016/j.gsf.2017.12.004.

Puetz, SJ, Ganade, CE, Zimmermann, U \& Borchardt, G 2018, 'Statistical analyses of Global U-Pb Database 2017', Geoscience Frontiers, vol. 9, no. 1, 2018/01/01/, pp. 121-145, DOI: 10.1016/j.gsf.2017.06.001.

[Dataset] Raymond, OL 2018, Australian Geological Provinces 2018.01 edition, Geoscience Australia, Canberra, Australian Capital Territory, http://pid.geoscience.gov.au/dataset/ga/116823.

Reid, AJ \& Hand, M 2012, 'Mesoarchean to Mesoproterozoic evolution of the southern Gawler Craton, South Australia', Episodes, vol. 35, no. 1, pp. 216-225, DOI: 10.18814/epiiugs/2012/v35i1/021.

Reid, AJ \& Jagodzinski, EA (eds) 2011, PACE Geochronology: Results of collaborative geochronology projects 2009-2010, Report Book, 2011/00003, Geological Survey of South Australia, Adelaide, South Australia.

Reid, AJ, Jagodzinski, EA, Fraser, GL \& Pawley, MJ 2014, 'SHRIMP U-Pb zircon age constraints on the tectonics of the Neoarchean to early Paleoproterozoic transition within the Mulgathing Complex, Gawler Craton, South Australia', Precambrian Research, vol. 250, 2014/09/01/, pp. 27-49, DOI: 10.1016/j.precamres.2014.05.013.

Reid, AJ \& Payne, JL 2017, 'Magmatic zircon Lu-Hf isotopic record of juvenile addition and crustal reworking in the Gawler Craton, Australia', Lithos, vol. 292-293, 2017/11/01/, pp. 294-306, DOI: 10.1016/j.lithos.2017.08.010.

Richards, NC 1982, Walkandi 1 - well completion report, no. WCR 04744, Delhi Petroleum Pty Ltd, <https://sarigbasis.pir.sa.gov.au/WebtopEw/ws/samref/sarig1/wci/Record?r=0\&m=1\&w=catno=20 28399>. 
This accepted manuscript is a post-print version made available as per Elsevier's sharing policy under a CC-BY-NC-ND license. The final peer reviewed publication in Precambrian Research can be found at https://doi.org/10.1016/i.precamres.2020.105849

Rooney, AD, Yang, C, Condon, DJ, Zhu, M \& Macdonald, FA 2020, 'U-Pb and Re-Os geochronology tracks stratigraphic condensation in the Sturtian snowball Earth aftermath', Geology, DOI: 10.1130/G47246.1.

Rose, CV, Maloof, AC, Schoene, B, Ewing, RC, Linnemann, U, Hofmann, M \& Cottle, JM 2013, 'PAUL F. HOFFMAN SERIES The End-Cryogenian Glaciation of South Australia', Geoscience Canada, vol. 40, no. 4, pp. 256-293, DOI: 10.12789/geocanj.2013.40.019.

Santosh, M 2010, 'Supercontinent tectonics and biogeochemical cycle: A matter of 'life and death", Geoscience Frontiers, vol. 1, no. 1, pp. 21-30, DOI: 10.1016/j.gsf.2010.07.001.

Schmidt, PW \& Williams, GE 1995, 'The Neoproterozoic climatic paradox: Equatorial palaeolatitude for Marinoan glaciation near sea level in South Australia', Earth and Planetary Science Letters, vol. 134, no. 1, 1995/08/01/, pp. 107-124, DOI: 10.1016/0012-821X(95)00106-M.

Schmitt, RdS, Fragoso, RdA \& Collins, AS 2018, 'Suturing Gondwana in the Cambrian: The Orogenic Events of the Final Amalgamation', in S Siegesmund, MAS Basei, P Oyhantçabal \& S Oriolo (eds), Geology of Southwest Gondwana, Springer International Publishing, Cham, pp. 411-432.

Shaanan, U, Rosenbaum, G \& Sihombing, FMH 2018, 'Continuation of the Ross-Delamerian Orogen: insights from eastern Australian detrital-zircon data', Australian Journal of Earth Sciences, vol. 65, no. 7-8, 2018/11/17, pp. 1123-1131, DOI: 10.1080/08120099.2017.1354916.

Shahin, S 2016, 'Structural analysis and facies distribution of Cryogenian glacial rocks and regional structures in the Willouran Ranges, SA', School of Physical Sciences, Honours thesis, B.Sc.(Hons) thesis, University of Adelaide, Adelaide, South Australia, <http://hdl.handle.net/2440/121230>.

Sheibner, E \& Basden, H (eds) 1998, Geology of New South Wales - Synthesis, vol. 13(2), Geology Memoir, Department of Mineral Resources, Sydney, New South Wales.

Sláma, J, Košler, J, Condon, DJ, Crowley, JL, Gerdes, A, Hanchar, JM, Horstwood, MSA, Morris, GA, Nasdala, L, Norberg, N, Schaltegger, U, Schoene, B, Tubrett, MN \& Whitehouse, MJ 2008, 'Plešovice zircon A new natural reference material for $\mathrm{U}-\mathrm{Pb}$ and $\mathrm{Hf}$ isotopic microanalysis', Chemical Geology, vol. 249, no. 1, 2008/03/30/, pp. 1-35, DOI: 10.1016/j.chemgeo.2007.11.005.

Smithies, RH, Howard, HM, Evins, PM, Kirkland, CL, Bodorkos, S \& Wingate, MTD 2008, The west Musgrave Complex - new geological insights from recent mapping, geochronology, and geochemical studies, Record, no. 2008/19, Geological Survey of Western Australia, <http://dmpbookshop.eruditetechnologies.com.au/product/the-west-musgrave-complex-newgeological-insights-from-recent-mapping-geochronology-and-geochemical-studies.do>.

Smithies, RH, Howard, HM, Evins, PM, Kirkland, CL, Kelsey, DE, Hand, M, Wingate, MTD, Collins, AS \& Belousova, EA 2011, 'High-Temperature Granite Magmatism, Crust-Mantle Interaction and the Mesoproterozoic Intracontinental Evolution of the Musgrave Province, Central Australia', Journal of Petrology, vol. 52, no. 5, pp. 931-958, DOI: 10.1093/petrology/egr010.

Smits, RG, Collins, WJ, Hand, M, Dutch, R \& Payne, JL 2014, 'A Proterozoic Wilson cycle identified by Hf isotopes in central Australia: Implications for the assembly of Proterozoic Australia and Rodinia', Geology, vol. 42, no. 3, pp. 231-234, DOI: 10.1130/G35112.1.

Spaggiari, CV, Kirkland, CL, Smithies, RH, Wingate, MTD \& Belousova, E 2015, 'Transformation of an Archean craton margin during Proterozoic basin formation and magmatism: The Albany-Fraser Orogen, Western Australia', Precambrian Research, vol. 266, 2015/09/01/, pp. 440-466, DOI: 10.1016/j.precamres.2015.05.036.

Spencer, CJ, Kirkland, CL \& Taylor, RJM 2016, 'Strategies towards statistically robust interpretations of in situ U-Pb zircon geochronology', Geoscience Frontiers, vol. 7, no. 4, 2016/07/01/, pp. 581-589, DOI: 10.1016/j.gsf.2015.11.006.

Sprigg, RC 1948, 'Jellyfish from the Basal Cambrian in South Australia', Nature, vol. 161, 04/10/online, p. 568, DOI: $10.1038 / 161568 \mathrm{aO}$.

Sprigg, RC 1952, 'Sedimentation in the Adelaide Geosyncline and the formation of the continental terrace', in MF Glaessner \& RC Sprigg (eds), Sir Douglas Mawson Anniversary Volume, The University of Adelaide, South Australia, pp. 153-159.

Squire, RJ, Campbell, IH, Allen, CM \& Wilson, CJL 2006, 'Did the Transgondwanan Supermountain trigger the explosive radiation of animals on Earth?', Earth and Planetary Science Letters, vol. 250, no. 1, 2006/10/15/, pp. 116-133, DOI: 10.1016/j.epsl.2006.07.032. 
This accepted manuscript is a post-print version made available as per Elsevier's sharing policy under a CC-BY-NC-ND license. The final peer reviewed publication in Precambrian Research can be found at https://doi.org/10.1016/i.precamres.2020.105849

1704

1705

1706

1707

1708

1709

1710

1711

1712

1713

1714

1715

1716

1717

1718

1719

1720

1721

1722

1723

1724

1725

1726

1727

1728

1729

1730

1731

1732

1733

1734

1735

1736

1737

1738

1739

1740

1741

1742

1743

1744

1745

1746

1747

1748

1749

1750

1751

1752

1753

1754

1755

1756
Squire, RJ \& Wilson, CJL 2005, 'Interaction between collisional orogenesis and convergent-margin processes: Evolution of the Cambrian proto-Pacific margin of East Gondwana', Journal of the Geological Society, vol. 162, no. 5, pp. 749-761, DOI: 10.1144/0016-764904-087.

Swain, G, Woodhouse, A, Hand, M, Barovich, K, Schwarz, M \& Fanning, CM 2005, 'Provenance and tectonic development of the late Archaean Gawler Craton, Australia; U-Pb zircon, geochemical and Sm-Nd isotopic implications', Precambrian Research, vol. 141, no. 3, 2005/11/20/, pp. 106-136, DOI: 10.1016/j.precamres.2005.08.004.

Teale, GS 1993, 'The Nooldoonooldoona Trondhjemite and other newly recognised Mesoproterozoic intrusives of the Mount Painter Province', Quarterly Geological Notes, vol. 125, January, pp. 20-31.

Thomson, BP 1970, 'A Review of the Precambrian and lower Palaeozoic Tectonics of South Australia', Transactions of the Royal Society of South Australia, vol. 94, pp. 193-221.

Turner, SP, Adams, CJ, Flöttmann, T \& Foden, JD 1993a, 'Geochemical and geochronological constraints on the Glenelg River Complex, western Victoria', Australian Journal of Earth Sciences, vol. 40, no. 3, 1993/06/01, pp. 275-292, DOI: 10.1080/08120099308728080.

Turner, SP, Foden, JD, Sandiford, M \& Bruce, D 1993b, 'Sm-Nd isotopic evidence for the provenance of sediments from the Adelaide Fold Belt and southeastern Australia with implications for episodic crustal addition', Geochimica et Cosmochimica Acta, vol. 57, no. 8, 1993/04/01/, pp. 1837-1856, DOI: 10.1016/0016-7037(93)90116-E.

Veevers, JJ, Belousova, EA, Saeed, A, Sircombe, KN, Cooper, AF \& Read, SE 2006, 'Pan-Gondwanaland detrital zircons from Australia analysed for $\mathrm{Hf}$-isotopes and trace elements reflect an ice-covered Antarctic provenance of 700-500 Ma age, TDM of 2.0-1.0 Ga, and alkaline affinity', Earth-Science Reviews, vol. 76, no. 3, 2006/06/01/, pp. 135-174, DOI: 10.1016/j.earscirev.2005.11.001.

Veevers, JJ, Walter, MR \& Scheibner, E 1997, 'Neoproterozoic Tectonics of Australia-Antarctica and Laurentia and the $560 \mathrm{Ma}$ Birth of the Pacific Ocean Reflect the 400 m.y. Pangean Supercycle', The Journal of Geology, vol. 105, no. 2, pp. 225-242, DOI: 10.1086/515914.

Vermeesch, P 2004, 'How many grains are needed for a provenance study?', Earth and Planetary Science Letters, vol. 224, no. 3, 2004/08/15/, pp. 441-451, DOI: 10.1016/j.epsl.2004.05.037.

Vermeesch, P 2012, 'On the visualisation of detrital age distributions', Chemical Geology, vol. 312-313, 2012/06/18/, pp. 190-194, DOI: 10.1016/j.chemgeo.2012.04.021.

Vermeesch, P 2013, 'Multi-sample comparison of detrital age distributions', Chemical Geology, vol. 341, 2013/03/11/, pp. 140-146, DOI: 10.1016/j.chemgeo.2013.01.010.

Vermeesch, P 2018a, 'Dissimilarity measures in detrital geochronology', Earth-Science Reviews, vol. 178, 2018/03/01/, pp. 310-321, DOI: 10.1016/j.earscirev.2017.11.027.

Vermeesch, P 2018b, 'IsoplotR: a free and open toolbox for geochronology', Geoscience Frontiers, 2018/04/11/, DOI: 10.1016/j.gsf.2018.04.001.

von der Borch, CC 1980, 'Evolution of late proterozoic to early paleozoic Adelaide foldbelt, Australia: Comparisons with postpermian rifts and passive margins', Tectonophysics, vol. 70, no. 1, 1980/12/01/, pp. 115-134, DOI: 10.1016/0040-1951(80)90023-2.

Wade, BP, Hand, M \& Barovich, KM 2005, 'Nd isotopic and geochemical constraints on provenance of sedimentary rocks in the eastern Officer Basin, Australia: implications for the duration of the intracratonic Petermann Orogeny', Journal of the Geological Society, vol. 162, no. 3, pp. 513-530, DOI: 10.1144/0016-764904-001.

Wade, BP, Kelsey, DE, Hand, M \& Barovich, KM 2008, 'The Musgrave Province: Stitching north, west and south Australia', Precambrian Research, vol. 166, no. 1, 2008/10/30/, pp. 370-386, DOI: 10.1016/j.precamres.2007.05.007.

Wade, CE 2011, 'Definition of the Mesoproterozoic Ninnerie Supersuite, Curnamona Province, South Australia', MESA Journal, vol. 62, September 2011, pp. 25-42.

Wade, CE, McAvaney, SO \& Gordan, GA 2014, 'The Beda Basalt: new geochemistry, isotopic data and its definition', MESA Journal, vol. 73, no. 2, 2014, pp. 24-39.

Walter, MR \& Veevers, JJ 1997, 'Australian Neoproterozoic palaeogeography, tectonics, and supercontinental connections', AGSO Journal of Australian Geology and Geophysics, vol. 17, no. 1, pp. 73-92, https://www.scopus.com/inward/record.uri?eid=2-s2.0$0031396162 \&$ partnerID $=40 \& \mathrm{md5}=41 \mathrm{ab} 53 \mathrm{bf} 1 \mathrm{fca} e 69 \mathrm{a} 22 \mathrm{c} 9896348840 \mathrm{a} 9$. 
This accepted manuscript is a post-print version made available as per Elsevier's sharing policy under a CC-BY-NC-ND license. The final peer reviewed publication in Precambrian Research can be found at https://doi.org/10.1016/i.precamres.2020.105849

Walter, MR, Veevers, JJ, Calver, CR, Gorjan, P \& Hill, AC 2000, 'Dating the 840-544 Ma Neoproterozoic interval by isotopes of strontium, carbon, and sulfur in seawater, and some interpretative models', Precambrian Research, vol. 100, no. 1, 2000/03/01/, pp. 371-433, DOI: 10.1016/S03019268(99)00082-0.

Ward, JF, Verdel, C, Campbell, MJ, Leonard, N \& Duc Nguyen, A 2019, 'Rare earth element geochemistry of Australian Neoproterozoic carbonate: Constraints on the Neoproterozoic oxygenation events', Precambrian Research, vol. 335, 2019/12/01/, p. 105471, DOI: 10.1016/j.precamres.2019.105471.

Webb, AW 1980, Geochronology of stratigraphically significant rocks from South Australia. Progress Report No. 30, no. Env 01689, Amdel Ltd, South Australia, <https://sarigbasis.pir.sa.gov.au/WebtopEw/ws/samref/sarig1/wcir/Record?r=0\&m=1\&w=catno=20 21979>.

Webb, AW \& Coats, RP 1980, Re-assessment of the age of the Beda Volcanics on the Stuart Shelf, South Australia, Report Book, no. 80/00006, Department of Mines and Energy, Adelaide, South Australia, $<$ https://sarigbasis.pir.sa.gov.au/WebtopEw/ws/samref/sarig1/wci/Record? $\mathrm{r}=0 \& \mathrm{~m}=1 \& \mathrm{w}=$ catno $=10$ 08450>.

Webb, AW, Coats, RP, Fanning, CM \& Flint, RB 1983, 'Geochronological Framework of the Adelaide Geosyncline', in Adelaide Geosyncline Sedimentary Environments and Tectonics Settings Symposium, Geological Society of Australia, Sydney, New South Wales, pp. 7-9.

Webb, AW \& Hörr, G 1978, 'The Rb-Sr age and petrology of a flow from the Beda Volcanics', Quarterly Geological Notes, vol. 66, pp. 10-13.

Wen, B, Evans, DAD \& Li, Y-X 2017, 'Neoproterozoic paleogeography of the Tarim Block: An extended or alternative "missing-link" model for Rodinia?', Earth and Planetary Science Letters, vol. 458, 2017/01/15/, pp. 92-106, DOI: 10.1016/j.epsl.2016.10.030.

Wen, B, Evans, DAD, Wang, C, Li, Y-X \& Jing, X 2018, 'A positive test for the Greater Tarim Block at the heart of Rodinia: Mega-dextral suturing of supercontinent assembly', Geology, vol. 46, no. 8, pp. 687-690, DOI: $10.1130 / G 40254.1$.

Wendt, I \& Carl, C 1991, 'The statistical distribution of the mean squared weighted deviation', Chemical Geology: Isotope Geoscience section, vol. 86, no. 4, 1991/04/05/, pp. 275-285, DOI: 10.1016/01689622(91)90010-T.

Wiedenbeck, M, AllÉ, P, Corfu, F, Griffin, WL, Meier, M, Oberli, F, Quadt, AV, Roddick, JC \& Spiegel, W 1995, 'THREE NATURAL ZIRCON STANDARDS FOR U-TH-PB, LU-HF, TRACE ELEMENT AND REE ANALYSES', Geostandards Newsletter, vol. 19, no. 1, 1995/04/01, pp. 1-23, DOI: 10.1111/j.1751908X.1995.tb00147.x.

Wilde, SA \& Spaggiari, C 2007, 'Chapter 3.6 The Narryer Terrane, Western Australia: A Review', in MJ van Kranendonk, RH Smithies \& VC Bennett (eds), Developments in Precambrian Geology, vol. 15, Elsevier, pp. 275-304.

Williams, GE 1986, 'The Acraman Impact Structure: Source of Ejecta in Late Precambrian Shales, South Australia', Science, vol. 233, no. 4760, pp. 200-203, http://www.jstor.org/stable/1697185.

Williams, GE \& Gostin, VA 2005, 'Acraman - Bunyeroo impact event (Ediacaran), South Australia, and environmental consequences: twenty-five years on', Australian Journal of Earth Sciences, vol. 52, no. 4-5, 2005/09/01, pp. 607-620, DOI: 10.1080/08120090500181036.

Willis, IL, Brown, RE, Stroud, WJ \& Stevens, BPJ 1983, 'The early Proterozoic Willyama supergroup: Stratigraphic subdivision and interpretation of high to low - grade metamorphic rocks in the Broken Hill Block, New South Wales', Journal of the Geological Society of Australia, vol. 30, no. 1-2, 1983/07/01, pp. 195-224, DOI: 10.1080/00167618308729249.

Wingate, MTD, Campbell, IH, Compston, W \& Gibson, GM 1998, 'Ion microprobe U-Pb ages for Neoproterozoic basaltic magmatism in south-central Australia and implications for the breakup of Rodinia', Precambrian Research, vol. 87, no. 3, 1998/02/01/, pp. 135-159, DOI: 10.1016/S03019268(97)00072-7.

Wingate, MTD \& Giddings, JW 2000, 'Age and palaeomagnetism of the Mundine Well dyke swarm, Western Australia: implications for an Australia-Laurentia connection at $755 \mathrm{Ma}$ ', Precambrian Research, vol. 100, no. 1, 2000/03/01/, pp. 335-357, DOI: 10.1016/S0301-9268(99)00080-7. 
This accepted manuscript is a post-print version made available as per Elsevier's sharing policy under a CC-BY-NC-ND license. The final peer reviewed publication in Precambrian Research can be found at https://doi.org/10.1016/i.precamres.2020.105849

Wingate, MTD, Pisarevsky, SA \& Evans, DAD 2002, 'Rodinia connections between Australia and Laurentia: no SWEAT, no AUSWUS?', Terra Nova, vol. 14, no. 2, 2002/04/01, pp. 121-128, DOI: 10.1046/j.13653121.2002.00401.x.

Woodget, AL 1987, 'The petrology, geochemistry and tectonic setting of basic volcanics on the Stuart Shelf and in the Adelaide Geosyncline, South Australia', Department of Geology and Geophysics, B.Sc(Hons) thesis, The University of Adelaide, Adelaide, South Australia, <http://hdl.handle.net/2440/86641>.

Wopfner, H 1972, 'Depositional history and tectonics of South Australian sedimentary basins', Mineral Resources Review, South Australia, vol. 133.

Wyche, S 2007, 'Chapter 2.6 Evidence of Pre-3100 Ma Crust in the Youanmi and South West Terranes, and Eastern Goldfields Superterrane, of the Yilgarn Craton', in MJ van Kranendonk, RH Smithies \& VC Bennett (eds), Developments in Precambrian Geology, vol. 15, Elsevier, pp. 113-123.

Yang, B, Smith, TM, Collins, AS, Munson, TJ, Schoemaker, B, Nicholls, D, Cox, GM, Farkas, J \& Glorie, S 2018, 'Spatial and temporal variation in detrital zircon age provenance of the hydrocarbon-bearing upper Roper Group, Beetaloo Sub-basin, Northern Territory, Australia', Precambrian Research, vol. 304 , 2018/01/01/, pp. 140-155, DOI: 10.1016/j.precamres.2017.10.025.

Zang, W-L, Jago, JB, Alexander, EM \& Paraschivoiu, E 2004, 'A review of basin evolution, sequence analysis and petroleum potential of the frontier Arrowie Basin, South Australia', in PJ Boult, DR Johns \& SC Lang (eds), Eastern Australian Basins Symposium II, Petroleum Exploration Society of Australia, Adelaide, pp. 243-256. 


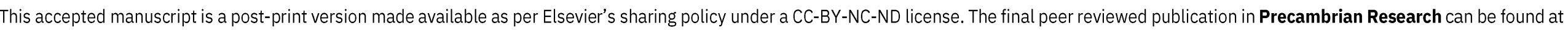
https://doi.org/10.1016/j.precamres.2020.105849

\section{Appendix One}




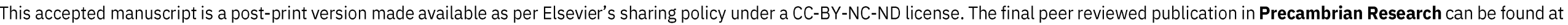
https://doi.org/10.1016/i.precamres.2020.105849

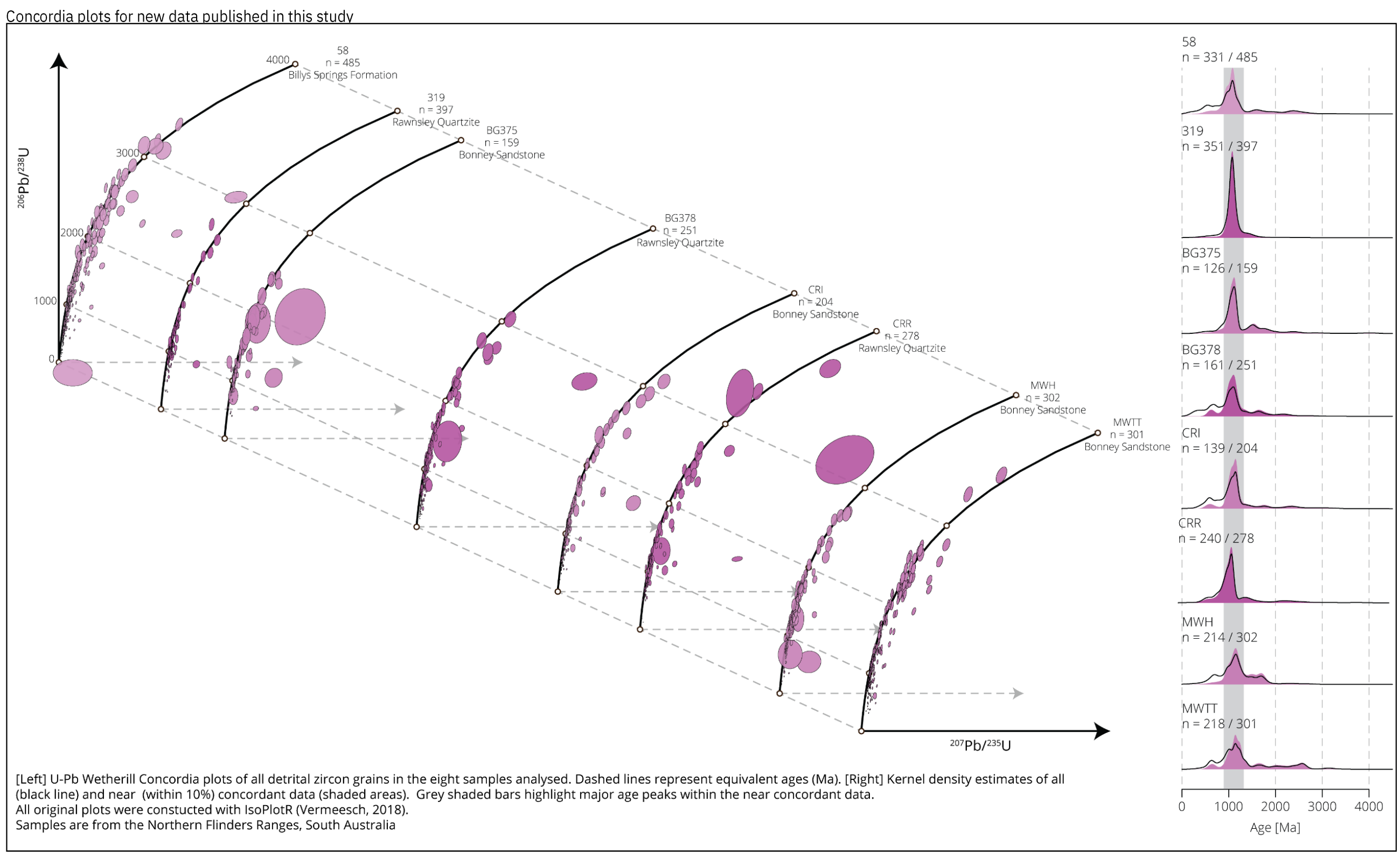




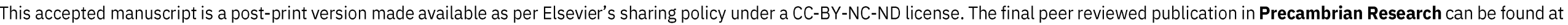
https://doi.org/10.1016/i.precamres.2020.105849
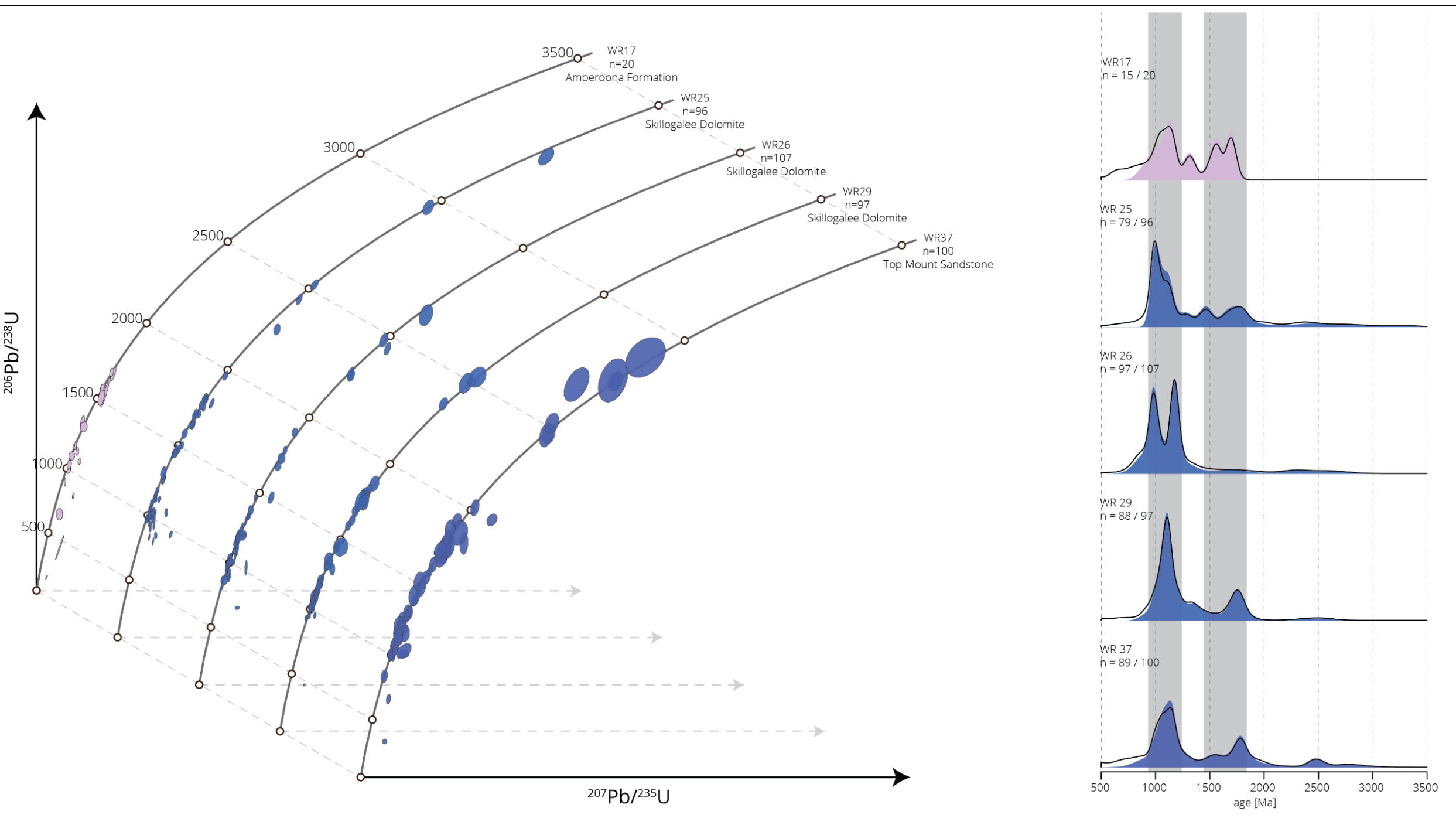

[Left] U-Pb Wetherill Concordia plots of all detrital zircon grains in the five samples analysed. Dashed lines represent equivalent ages (Ma). [Right] Kernel density estimates of all (black line) and near (within 10\%) concordant data (shaded areas). Grey shaded bars highlight major age peaks within the near concordant data.

All original plots were constucted with IsoPlotR (Vermeesch, 2018)

Samples are from the Willouran Ranges, South Australia 


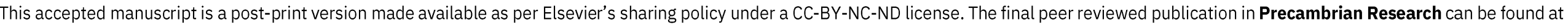
https://doi.org/10.1016/i.precamres.2020.105849

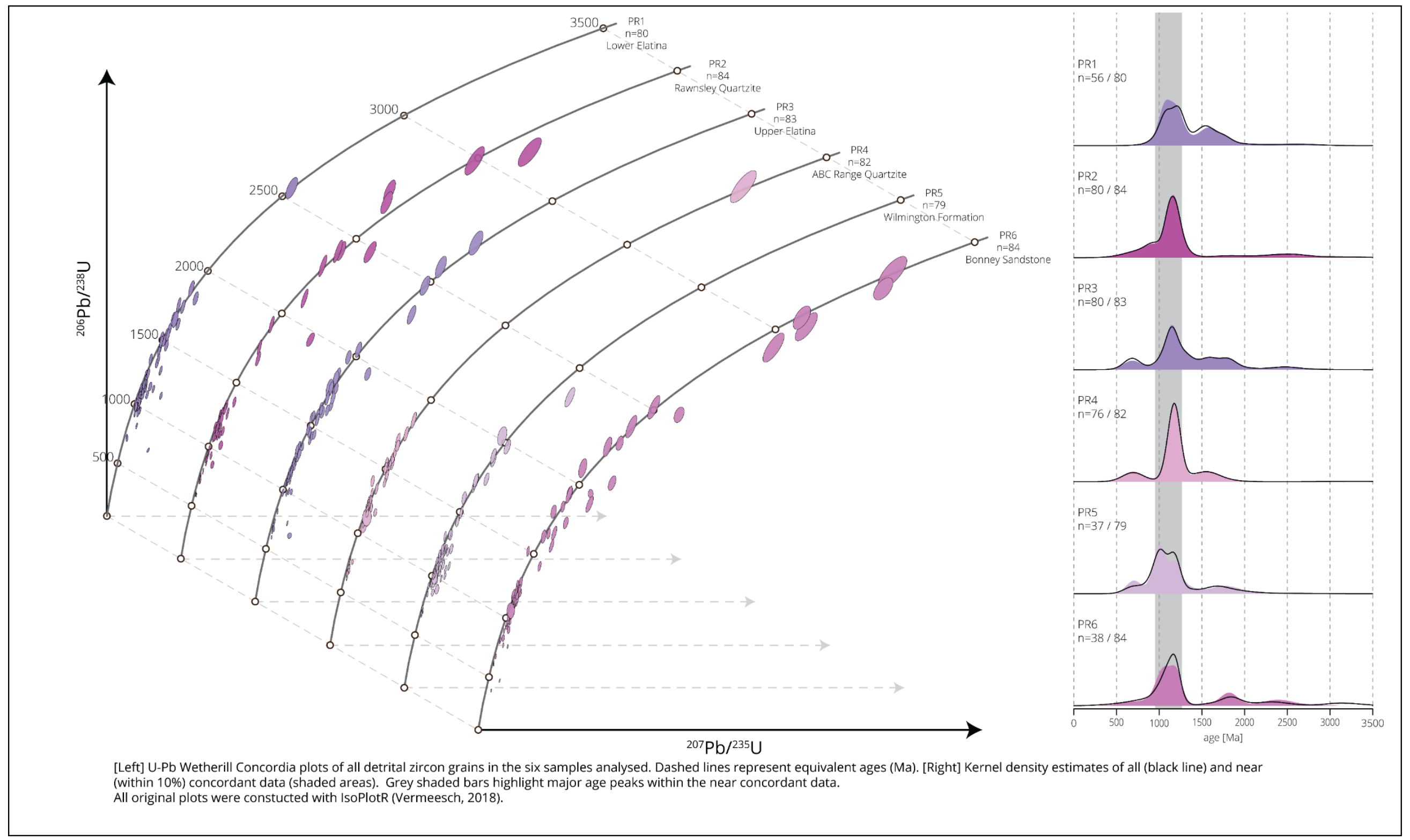




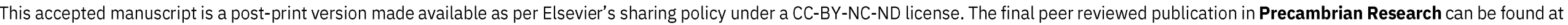
https://doi.org/10.1016/j.precamres.2020.105849

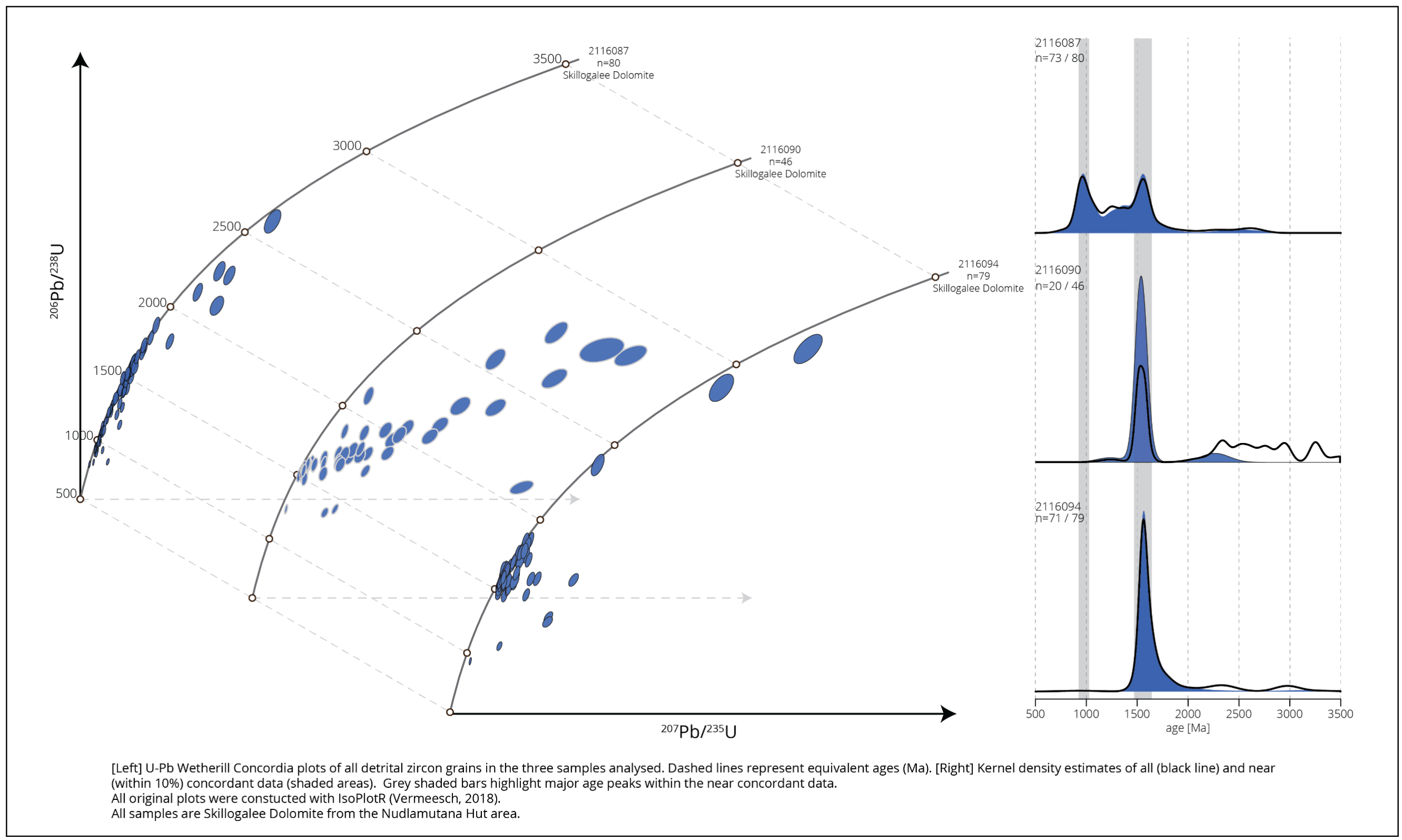




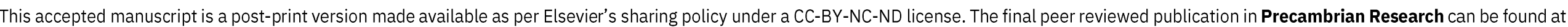
https://doi.org/10.1016/j.precamres.2020.105849 